\author{
UNIVERSIDADE DE SÃO PAULO \\ FACULDADE DE EDUCAÇÃO \\ PROGRAMA DE PÓS-GRADUAÇÃO EM EDUCAÇÃO \\ ÁREA ENSINO DE CIÊNCIAS E MATEMÁTICA
}

O CURRÍCULO NA CONSTRUÇÃO DO CONHECIMENTO GEOGRÁFICO: UM ESTUDO DA AÇÃO DOCENTE DE DUAS ESCOLAS ESTADUAIS DE SÃO PAULO

ANA CLAUDIA RAMOS SACRAMENTO

São Paulo

2007 


\title{
O CURRÍCULO NA CONSTRUÇÃO DO CONHECIMENTO GEOGRÁFICO: UM ESTUDO DA AÇÃO DOCENTE DE DUAS ESCOLAS ESTADUAIS DE SÃO PAULO
}

\author{
Dissertação de mestrado apresentada ao Programa de \\ Pós-Graduação da Faculdade de Educação da USP \\ $\mathrm{Na}$ Área de Ensino de Ciências e Matemática como \\ requisito final para obtenção do título de Mestre em Educação
}

Orientadora: Prof. ${ }^{a}$ Dr. ${ }^{a}$ Sônia Maria Vanzella Castellar 
AUTORIZO A REPRODUÇÃO E DIVULGAÇÃO TOTAL OU PARCIAL, DESTE TRABALHO, POR QUALQUER MEIO CONVENCIONAL OU ELETRÔNICO PARA FINS DE ESTUDO E PESQUISA, DESTE QUE CITADA A FONTE.

Catalogação na Publicação

Serviço de Documentação

Faculdade de Educação da Universidade de São Paulo

Sacramento, Ana Claudia Ramos.

O currículo na construção do conhecimento geográfico: um estudo da ação docente de duas escolas estaduais de São Paulo./ Ana Claudia Ramos Sacramento; orientadora: Sônia Maria Vanzella Castellar - São Paulo, 2007.

p. 291

Dissertação (Mestrado - Programa de Pós-Graduação em Educação. Área Ensino de Ciências e Matemática) - Faculdade de Educação da Universidade de São Paulo.

1. Organização Curricular. 2. Formação de Professores. 3. Ensino de Geografia.

4. Espaço produzido. 5. Espaço vivido. 


\section{DEDICATÓRIA ESPECIAL 1}

Ao Meu SENHOR JESUS CRISTO que me deu forças para suportar as saudades da minha família, da minha igreja e dos meus amigos. Tudo que sou e tudo que tenho, devo a ELE que me salvou e me libertou!

A ELE dedico a minha vida! A possibilidade de ser uma pessoa melhor todos os dias e que não me desamparou em momentos mais difíceis!

"Quando você atravessar as águas,

Eu estarei com você; Quando você atravessar os rios,

Eles não o encobrirão.

Quando você andar através do fogo,

Não as queimará; As chamas não o deixarão em brasas.

Pois eu sou o SENHOR, O seu DEUS".

(Isaías 43.2-3) 
Dedico este trabalho a minha querida mãe "Preta", que sempre nos dizia que os filhos deveriam ser melhor que os pais. Ela que sacrificou muitas vezes a sua vida para nos ensinar e nos dar o melhor: amor, honestidade, carinho e alegria. Esta é a minha mãe que me apoiou e me abençoou para que eu completasse um sonho não só meu, mas de toda minha humilde família.

Ao meu irmão "Xandelly" que apesar de nossas brigas, sempre me ajudou quando precisei!!!! 


\section{AGRADECIMENTOS}

À minha igreja "I Batista do Porto Novo" que orou por mim todo esse tempo para que eu me adaptasse a essa "nova" vida, sempre estando nos caminhos do Senhor. Agradeço especialmente aos irmãos: Chiquinho e Jane Luci, Odi, Marlene e Adriana, Andrea e Patrícia, Bárbara, Lisa, Regina e Neli, que sempre tiveram um gesto carinhoso quando ia para casa, e ficavam chateados com as minhas partidas, mas felizes por um sonho a ser realizado.

À Lídia Helena, Maria Luíza Kede, Leandro Dias, Patrícia Manuela, meus amigos e companheiros de profissão que muitas das vezes ouviram as minhas angústias e minhas dúvidas. Obrigada!

À Jerusa Vilhena e a Gislaine Munhoz, minhas queridas amigas de São Paulo, que sempre me ouvem, me aconselham e fazem com que me sinta melhor, apesar de estar longe da minha família.

Aos meus outros amigos de São Paulo: Claudia Saud, Ana Claudia, Simone Falconi, Fernanda Almeida, Juraci que estiveram comigo neste período de mudança de vida!

À Dona Carmelita que me "abrigou” em sua casa, uma pessoa que ela nem conhecia, mas que o Senhor Jesus já havia preparado para que entrasse na minha vida. Agradeço pela oportunidade de conviver com uma pessoa fina, generosa e amável como ela.

À Secretaria de Educação de São Paulo que me ofereceu uma bolsa para que eu pudesse fazer minha pesquisa com uma menor carga horária de trabalho.

À Faculdade de Educação da USP e a todos os professores com quem estudei ou fui bolsista, aprendi mais o que é essa arte de pesquisar!

Aos Professores da Faculdade de Formação de Professores (FFP-UERJ) em especial ao Prof. Marcos Couto, meu orientador na graduação, meu companheiro de discussões sobre um ensino de Geografia "melhor"! Também ao Prof. Andrelino Campos, meu “outro" orientador que com seu carinho e inteligência me apoia sempre!

Aos diretores e coordenadores das Escolas Estaduais Ruth Cabral Troncadelli e Manuela Lacerda Vergueiro que me permitiram realizar a pesquisa e "atrapalhar" as suas reuniões. 
Aos queridos professores Nelson, Maria Rosa, Izilda, Claudia, Lucia, Cenira e Claudete e aos seus alunos que tornaram possível a conclusão desse trabalho. Sei o quanto foi difícil e cansativo me ver quase sempre nas salas de aula e durante as reuniões. Obrigada por conhecer pessoas tão amáveis e lutadoras como vocês!

Por último, não menos importante, agradeço a minha querida orientadora Sônia Maria Vanzella Castellar, meio paulista/meio carioca, que acreditou sem conhecer sua orientanda "NEGRA, ALTA E CARIOCA". Com a sua simpatia e inteligência me permitiu desenvolver o trabalho com total liberdade! Obrigada por me dar essa oportunidade de trabalhar ao seu lado. 
SACRAMENTO, Ana Claudia Ramos. O currículo na construção do conhecimento geográfico: um estudo da ação docente de duas escolas estaduais de São Paulo. 2007. 291 f. Dissertação de mestrado - Faculdade de Educação, Universidade de São Paulo, São Paulo, 2007.

\section{Resumo}

Trata-se de uma pesquisa sobre o currículo da Geografia escolar, analisando a articulação entre a prática docente e a teoria geográfio-pedagógica, tendo como foco o desenvolvimento da percepção vivida pelos alunos sobre a Geografia. A organização curricular é entendida como uma "ação" dos professores para estruturar os conteúdos e os conceitos, a metodologia, a didática e sua concepção das ciências para repensar sobre prática na busca de um ensino que inter-relacione as questões do vivido e produzido da sociedade em que o aluno está inserido. Nas últimas décadas, vários foram os estudos que indicam a articulação do conhecimento, a partir do momento em que o professor se reconheça como pesquisador, mediador e orientador desse conhecimento. Ao elaborar o currículo escolar de geografia, o professor deve não só destacar os conteúdos relacionados à ciência geográfica como também organizar suas ações didáticas, com a perspectiva de uma transformação do conhecimento do aluno, e este compreenda a importância da Geografia. Uma das preocupações do professor ao organizar o currículo é articular as aulas e o conhecimento do aluno em relação ao seu cotidiano. Portanto, deve entender os fenômenos geográficos que estão inseridos. Com relação à utilização da pesquisa qualitativa, a opção pela pesquisa-ação permite romper com a dicotomia pesquisador/objeto e passa-se a trabalhar numa inter-relação pesquisador-sujeito-objeto, com base nas referências teóricas de Fiorentini, Silva e Thiollent; Coll e Sacristán discutem sobre a organização curricular pensando numa questão mais prática do currículo, de sua construção e de sua aplicação para uma produção sistematizada e orientada dos trabalhos na escola; enquanto Callai, Capel, Castellar, Cavalcanti, Lacoste debatem a questão do ensino de Geografia, seus conceitos, seus conteúdos, sua história, a formação do docente e a construção do conhecimento do aluno. No resultado final da pesquisa, a produção curricular realizada pelos professores possibilitou novos olhares sobre suas ações didáticas, permitindo o trabalho sobre as questões do cotidiano e o conhecimento dos alunos em sala.

Unitermos: Organização curricular, Formação de professores, Ensino de Geografia, Espaço vivido, Espaço produzido. 
SACRAMENTO, Ana Claudia Ramos. The curriculum in geographic knowledge building: a study of teaching action from the state network of São Paulo (Master degree dissertation) - Faculdade de Educação, Universidade de São Paulo, São Paulo, 2007.

\begin{abstract}
This is a research about the school Geography curriculum, taking into account the articulation between teaching practice and pedagogic-geographical theory, focusing on the development of students experienced perception about Geography. The curricular organization is understood as a teacher's "action" in order to structure the contents and concepts, methodology, didactic, and their conception of sciences to think over the practice in search of teaching that interrelates the issues of the lived and produced space of society where the student is inserted. In the last decades, several studies have shown the knowledge articulation, from the moment the teacher becomes a researcher, mediator, and advisor of this knowledge. When elaborating the school geography curriculum, the teacher should not only highlight the contents related to geographical science, but also organize their didactic actions, expecting to change the student's knowledge, and as a consequence, the student will understand the importance of Geography. One of teacher's concerns when organizing the curriculum is to articulate classes with student's knowledge regarding to their everyday life. Therefore, the teacher must understand the geographical phenomena they are inserted in. Regarding to qualitative research use, a research-action was chosen in order to break with the dichotomy research/object and begin to work with an interrelation researcher-subjectobject, based on theoretical references of Fiorentini, Silva and Thiollent; Coll and Sacristán discuss about the curricular organization, approaching a more practical issue of the curriculum, its application and building a systematic and oriented production of school work; whereas Callai, Capel, Castellar, Cavalcanti, Lacoste debate the issue of Geography teaching, its concepts, contents, history, teaching formation, and the student knowledge building. In the research final result, the curricular production done by the teachers enabled new views on their didactic actions, allowing the work about everyday issues and students knowledge in classroom.
\end{abstract}

Uniterms: Curricular Organization, Teachers Education, Geography Teaching, Lived Space, Produced Space. 


\section{SUMÁRIO}

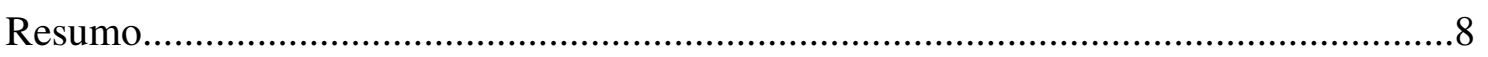

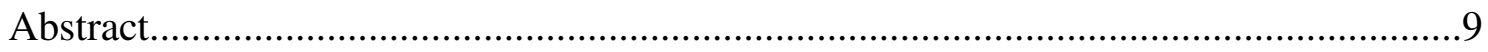

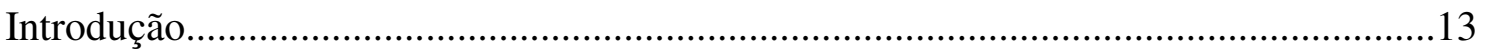

A pesquisa-ação: os caminhos de uma metodologia.......................................................19

Capítulo I. Conhecendo os agentes da produção dos elementos curriculares do Ensino de Geografia: as escolas, os professores e os alunos

1.1 As escolas: os espaços de mediação entre o docente, o aluno e o saber para a produção curricular do conhecimento do cotidiano

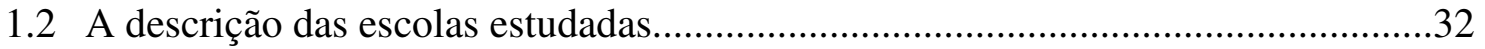

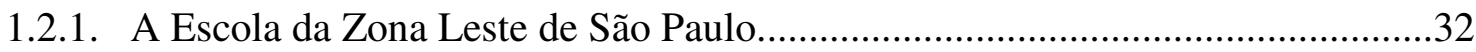

1.2.2. A Escola da Zona Sul de São Paulo.......................................................................

1.3 A valorização dos agentes da construção do conhecimento do vivido:

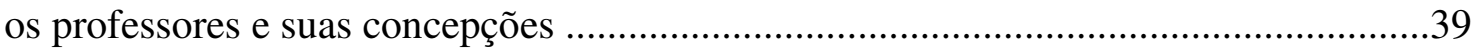

1.3.1. Dados dos professores da Escola da Zona Leste...............................................47

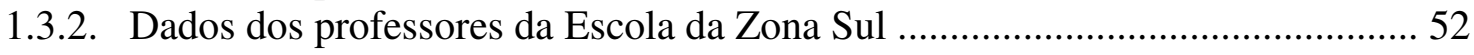

1.3.3. Análise dos dados dos professores apresentados...............................................56

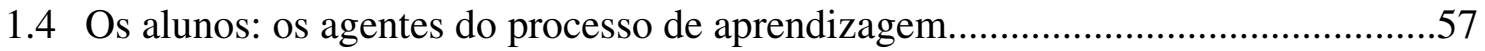

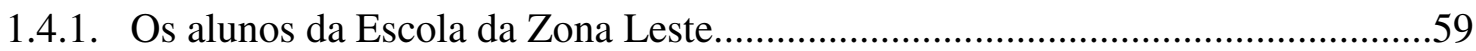

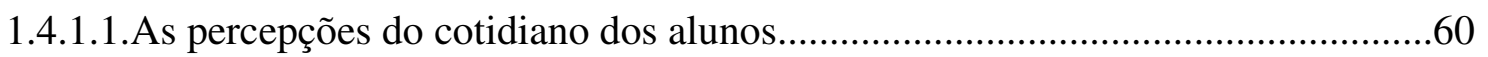

1.4.2. Os alunos da Escola da Zona Sul..................................................................64

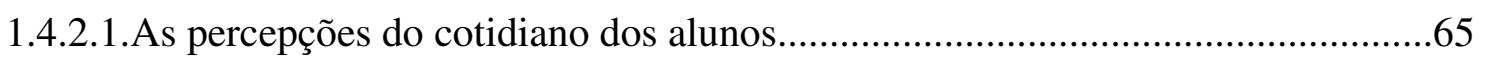

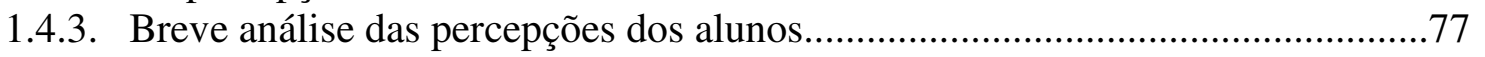

Capítulo II: A construção dos elementos curriculares de Geografia.

A produção atual em duas escolas estaduais no município de São Paulo

2.1. O movimento do currículo para compreensão de sua produção.

2.2. A produção de elementos curriculares: o caso de duas escolas estaduais de São Paulo.

2.2.1. Alguns elementos da Proposta Curricular organizada pelos professores de

Geografia da Escola da Zona Leste.

2.2.2. Alguns elementos da Proposta Curricular organizada pelos

professores de Geografia da Escola da Zona Sul....

2.2.3. Análise dos elementos curriculares apresentados.

2.3. A história do currículo de Geografia contribuindo para compreensão da produção atual: uma revisão do processo curricular. 
2.4. A interligação entre a história curricular e a produção atual: pequenas considerações.

Capítulo III: A construção do currículo para a prática pedagógica: a concepção do espaço vivido ao produzido nas aulas de Geografia

3.1. A relação do ensino de Geografia e a realidade vivida do aluno:

elementos para prática pedagógica dos professores

3.2. Os elementos curriculares em ação: as aulas dos professores de Geograafia

3.2.1. Observação das aulas da Professora 2 da Escola da Zona Leste

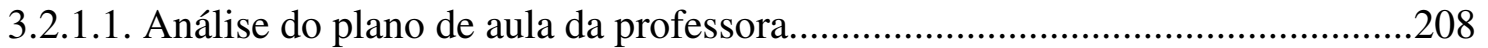

3.2.2. Observação das aulas da Professora 2 Escola da Zona Sul................................211

3.2.2.1. Análise do plano de aula da professora............................................................245

3.3. Análise geral dos trabalhos dos professores..........................................................248

Capítulo IV: As ações dos professores e a possibilidade de uma produção curricular

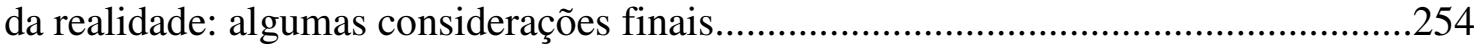

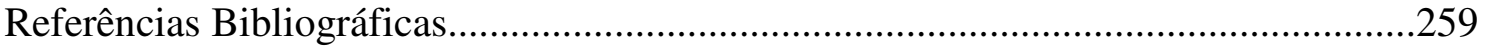

Anexos

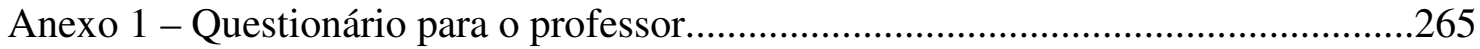

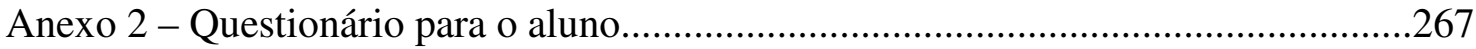

Anexo 3 - Trabalhos e atividades dos alunos da Escola da Zona Leste......................269

Anexo 4 - Trabalhos e atividades dos alunos da Escola da Zona Sul.........................284

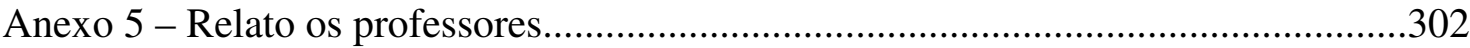

Ilustração

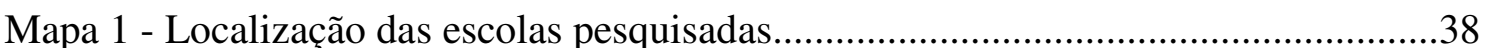

Tabelas

Tabela 1 - Informações gerais sobre os professores.................................................50

Tabela 2 - Informações gerais sobre os professores......................................................54 


\section{ÍNDICE}

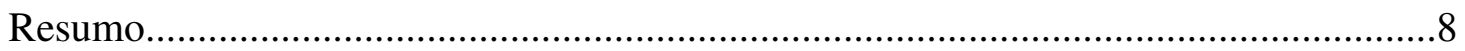

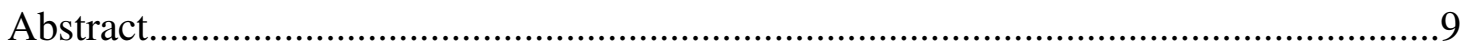

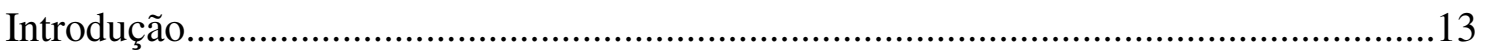

A pesquisa-ação: os caminhos de uma metodologia....................................................19

Capítulo I: Conhecendo os agentes da produção dos elementos curriculares do Ensino de Geografia: as escolas, os professores e os alunos.

Capítulo II: A construção dos elementos curriculares de Geografia. A produção atual em duas escolas estaduais no município de São Paulo.

Capítulo III: A construção do currículo para a prática pedagógica: a concepção do espaço vivido ao produzido nas aulas de Geografia.

Capítulo IV: As ações dos professores e a possibilidade de uma produção curricular da realidade: algumas considerações finais.

Referências Bibliográficas.

Anexos. 


\section{Introdução}

O ensino de Geografia está sempre em processo de mudanças, devido às transformações dentro da própria ciência geográfica na busca de repensar seus conceitos e sua utilização, mudanças, essas, que estão associadas às concepções educacionais. Uma das preocupações centrais da disciplina é fazer com que o aluno apreenda os fenômenos geográficos que são concebidos no seu cotidiano, conseqüentemente, a Geografia tem como princípio, dentro da escola, fazer com que o aluno seja capaz de entender a dinâmica da leitura de mundo por meio dos conceitos geográficos e de suas linguagens.

Para Apple (2001), Moreira, A. (2001), Silva (1999, 2001), repensar o currículo, é relacioná-lo a um objeto a ser construído, tornando-se um artefato político, social, educacional da Geografia Escolar, capaz de proporcionar aos alunos, conforme Cavalcanti (1999), valores, conhecimentos e outros aspectos relevantes na construção do conhecimento.

Ainda de acordo com Apple (2001), no currículo está inclusa a legitimidade política, social caracterizada por um ponto de vista de uma sociedade ou de um grupo, ou conforme Coll (1996) um elo entre a teoria educacional e a prática pedagógica, entre o planejamento e a ação, entre o que é prescrito e o que realmente ocorre nas salas de aula está direcionado a pensar o papel dos sujeitos do conhecimento: a escola, os professores e os alunos, principalmente o papel do docente como orientador, promotor e organizador desse processo de criação dos elementos curriculares.

As novas discussões de cunho teórico-metodológico na formação do professor trouxeram a necessidade de refletir sobre os cursos de formação, da didática, e de metodologia docente, bem como, a preocupação como os conteúdos estavam estruturados e organizados no currículo escolar. Como uma possibilidade de se repensar a Geografia e seu papel dentro de um mundo neoliberal e globalizado, os significados dos conteúdos e conceitos também devem ser outros. A Geografia permite o diálogo entre as concepções dos espaços vividos e produzidos pelo aluno e também do próprio professor por aqueles que acreditam numa escola de qualidade a qual pretende proporcionar ao aluno a leitura e a interpretação do mundo em que vive.

A construção deste currículo que articule o espaço vivido ao produzido possibilita que o processo curricular seja realizado e refletido pelos professores de Geografia, que farão com que o processo de ensino-aprendizagem seja verdadeiramente 
construído, à medida que a escola, enquanto instituição educacional, permita o desenvolvimento de uma prática reflexiva.

Os elementos curriculares de Geografia devem ser construídos por aqueles que os fazem agir, no caso, os professores que têm o compromisso de orientar os alunos a "aprender o conhecimento" e "transpô-lo" para a realidade. Para tanto, sabemos que o papel da Geografia na escola era legitimar o poder do Estado-Nação ao povo conforme Vlach (1988), Moreira (1986), Lacoste (1988).

Como os elementos curriculares têm muitas características, para a dissertação, escolhemos a organização dos conteúdos e as unidades didáticas, pois acreditamos que esses são os principais aspectos importantes dentro do currículo para a "construção" do ensino e aprendizagem e a busca de uma articulação entre a didática e a metodologia do professor que privilegie a produção da disciplina geográfica.

A Geografia Escolar, dentro dessa perspectiva, foi de suma importância para camuflar uma forma de estudar o espaço brasileiro no qual a constituição de uma nação brasileira foi sendo argumentada e "passada" para a massa. A idéia dos conceitos geográficos que foi trabalhada nas salas, estava elencada nos currículos nacionais. Território, paisagem, região, lugar, espaço, conceitos chaves de Geografia eram utilizados para a compreensão de uma disciplina que era utilizada pelo Estado com o fim de manipular a massa, ou seja, de camuflar a realidade vivenciada pela população, e não, como uma ciência que organizasse a compreensão analítica e crítica do espaço vivido e produzido por essa sociedade, e muito menos, pelo aluno.

Callai (2005), Cavalcanti (1998), Lacoste (1988) afirmam que a disciplina deve ajudar na construção crítica do cidadão por meio do saber pensar o espaço vivido não no senso comum, fazendo com que compreenda como as escalas local e global estão envolvidas no processo de transformação espacial, e por meio do cotidiano, fazer com que o aluno perceba a importância da Geografia e, ao mesmo tempo, como ele é um sujeito produzido e produtor dessa sociedade. Por isso, conforme Callai (1999):

"O conteúdo de Geografia, por ser essencialmente social, pois diz respeito ao espaço que o homem constrói e ao mesmo tempo que o recebe para fazer a sua morada e que tem a ver com as coisas concretas da vida que estão acontecendo e que tem a sua efetivação num espaço concreto aparente e visível, permite e encaminha o aluno a um aprendizado que faz parte da própria vida e como tal pode ser considerado em seu significado restrito e extrapolado para a condição social da humanidade". Callai (1999: 81). 
Pensamos que o papel do professor de Geografia é refletir sobre sua prática dentro e fora da sala de aula, e como ele, um mediador do conhecimento pode intervir, qualificar e proporcionar uma educação efetivamente geográfica. Por isso, acreditamos que ao produzir os elementos curriculares, a necessidade de reflexão ainda é maior, porque será englobado não só os conteúdos, mas a sua própria formação e de como procederá para que consiga relacionar sua teoria com a prática exercida.

O objetivo desta pesquisa é compreender o papel do currículo geográfico numa perspectiva de construção, por parte dos professores, na busca por uma prática na realidade vivida pelo aluno.

O problema foi estruturado na seguinte hipótese: partindo do pressuposto de que os professores deveriam refletir sobre a proposta curricular e construí-la, ela se torna fundamental para a organização do ensino de Geografia, por uma prática pedagógica que visa ao conhecimento do cotidiano dos alunos?

A temática sobre currículo é muito antiga, mas ao mesmo tempo, uma discussão importante na atualidade porque está estabelecendo uma relação de poder, de seletividade, de organização escolar. Se não fosse um tema interessante, o Governo Federal não teria programado os PCNs como currículo básico para a Educação Brasileira. Moreira e Silva (2001), afirmam essa importância dentro e fora do contexto escolar porque as práticas vivenciadas estabelecem uma organização que permite ou não entendimento pleno do que é viver numa sociedade, assim:

"O currículo é considerado um artefato social e cultural. Isso significa que ele é colocado na moldura mais amplas de suas determinações sociais, de sua história, de sua produção contextual... O currículo está implicado em relações de poder, o currículo transmite visões sociais particulares e interessadas, e o currículo produz identidades individuais e sociais particulares... ele tem uma história, vinculada a formas específicas e contingentes de organização de sociedade e da educação". Moreira e Silva (2001: 7-8).

A história educacional no Brasil nos remete a perceber a importância que cada currículo exerceu em cada época e como sua posição ideológica permeia as salas de aulas. A escola, espaço social e educativo, também é um espaço político, no qual uma ideologia é massificada para os alunos.

O papel da pesquisa desenvolvida foi pensar o mapeamento e o debate de uma construção de alguns elementos curriculares, baseando-se em que todo o professor seja 
construtor e mediador das atividades realizadas durante o ano letivo de duas escolas públicas estaduais no município de São Paulo.

Cremos que o papel do professor nesse desenvolvimento é a percepção de se pensar e de se organizar os conteúdos considerando a cotidianidade do indivíduo (aluno-educando) para que o sujeito possa entender, construir e desvendar sua própria espacialidade, colocar-se e compreender-se como um agente transformador.

A construção dos elementos curriculares de Geografia realizada pelo professor é crer, que como mediador do conhecimento, ele desenvolve a autonomia dessa produção, pois, na medida que, reflete sobre sua prática, sobre os seus erros, poderá modificar com a forma que desenvolve seu trabalho.

Conforme Castellar (2005), o professor ao estabelecer a importância e clareza de como exercer a construção da aprendizagem do seu aluno, reflete e define o que seja necessário para o conhecimento, sendo assim:

"Quando o professor define seus objetivos, estrutura os conteúdos, conceitos e conhece os seus alunos, fica mais fácil perceber e criar condições para que ocorra de fato uma aprendizagem significativa. Desse modo, consideramos que a aula tem uma função relevante, pois é o momento no qual se pode organizar o conhecimento e o pensamento do aluno, a partir de atividade de aprendizagem". Castellar (2005:220).

Por isso, pensar os conteúdos que fomentam o debate e a compreensão do vivido o qual se perceba as contradições das relações sociais dentro da organização espacial, mas também ligado às relações da sua afetividade, de simbolismo, da cultura, do lazer porque a produção dos conhecimentos dos alunos deve fazê-los entender a importância da Geografia na construção da sociedade.

Diante do exposto, os objetivos da pesquisa foram:

1. Análise da importância de se compreender o currículo de Geografia abarcando outros currículos de diferentes épocas para percepção de sua organização. Para tanto será realizada uma pesquisa no NUDOM Colégio Pedro II, por se tratar do primeiro colégio a realizar propostas curriculares para o ensino e comparar pelo menos 06 (seis) épocas distintas, observando o tipo de conteúdo e sua importância nesses 
períodos. Dessa maneira, vislumbraremos a concepção curricular e como a Geografia era ensinada;

2. Averiguar a história do pensamento geográfico escolar, avaliando a importância de uma outra concepção curricular na escola, na qual o professor será o produtor;

3. A importância da formação do docente de Geografia e a contribuição deste no processo de uma aprendizagem significativa para o aluno. Frisar a importância do, como mediador e produtor do conhecimento no processo de aprendizagem do aluno. O professor é quem conhece, convive e trabalha com esse aluno. Então, a sua valorização como profissional docente é uma questão de fazê-lo perceber a necessidade de uma reflexão sobre seu próprio trabalho;

4. Os caminhos que os professores tiveram para refletir e pensar em elementos curriculares (unidades didáticas e organização dos conteúdos) voltados para as suas concepções de Geografia e para o universo vivido, ou seja, como ele desenvolverá as atividades que serão pertinentes a um aprendizado voltado para a realidade de seu alunado, quais tipos de estratégias e argumentos o farão conduzir à proposta curricular desenvolvida por ele. Como o professor irá proceder para tornar o currículo presente em suas aulas, bem como os outros agentes: a escola e o aluno.

Acreditamos que o ensino de Geografia desenvolveu outras perspectivas: a busca por uma disciplina que promova a compreensão espacial da realidade vivida pelo aluno, a percepção dos fenômenos que ocorrem e transformam o meio físico, a relação do modo de produção que gera a luta de classe, e com isso, a transformação do espaço e ocupação de novos territórios; a mudança impressa na paisagem, o lugar e a identidade que o aluno vive com as novas configurações regionais no mundo, e tantas outras questões que modificam a Geografia nesse novo contexto do mundo moderno.

Esta dissertação está dividida em quatro capítulos, metodologia de pesquisa, referências bibliográficas e anexos.

No capítulo 1, caracterizamos os agentes da produção do conhecimento: as escolas, os professores e os alunos pesquisados, fazendo um balanço sobre cada um. Como a escola se estrutura nessa dimensão sócio-cultural e educativa; o que significa a 
formação dos professores para uma valorização de seu trabalho, com o objetivo de produzir os elementos curriculares que os façam repensar o seu trabalho na concepção de perceber o espaço vivido e produzido por ele e seus alunos; e estes como sujeitos centrais da aprendizagem.

No capítulo 2, o que significa o currículo e os seus movimentos para uma práxis educativa, considerando os elementos curriculares descritos pelos professores das escolas públicas de São Paulo como eles organizaram uma perspectiva de produzir o conhecimento, e a possibilidade de interação à realidade vivida da sociedade, e um resgate da história dos currículos de Geografia para mostrar como os documentos são importantes às concepções dos professores.

No capítulo 3, a execução dos elementos curriculares realizados pelos professores das escolas estudadas. Pesquisamos os trabalhos destes professores, buscando uma interligação entre a teoria e a prática, concretizadas nas elaborações dos planos de aulas e das atividades exercidas pelos seus alunos. Nesse momento, percebemos como os agentes do conhecimento se relacionam para o fundamento principal da educação, a construção do saber, no nosso caso, o saber geográfico por meio das concepções do espaço vivido ao socialmente produzido.

No capítulo 4, a relação final entre todos os elementos discutidos para que a cada dia possamos entender e produzir formas de melhorar a qualidade do trabalho na escola e da Geografia enquanto uma disciplina que possibilita o "pensar o espaço em que vive". 


\section{A pesquisa-ação: os caminhos de uma metodologia}

A escolha da metodologia para realizar a dinâmica de uma pesquisa é sempre um desafio. Decidimos fazer essa pesquisa qualitativa, com base, na pesquisa-ação, por acreditar que esta seja fruto de uma relação dinâmica, já que os sujeitos são os objetos desse trabalho e que, por sua vez, não podem ser traduzidos literalmente em números.

Nossa pesquisa foi desenvolvida na forma interpretativa, analítica de observação e produção de materiais de forma que os professores desenvolvessem em sua prática cotidiana. A interpretação dos dados foi analisada a partir das observações e coletas de dados em trabalhos de campo por meio de questionários, reuniões e observações das aulas.

Ao retratar a investigação qualitativa Bodgan e Biklen (1994) consideram cinco características importantes, para a formulação da pesquisa. Deste modo, citaremos as características de cada item, os quais, julgamos importantes para a compreensão da a pesquisa, de acordo, com as argumentações dos referidos autores:

1. A fonte direta dos dados é o ambiente natural, constituindo o investigador, o instrumento principal, ou seja, a escolha do lugar, dos equipamentos utilizados dependerá do pesquisador e de sua ação. No nosso caso, o ambiente: duas escolas estaduais no município de São Paulo, uma na Zona Leste e outra na Zona Sul. Nas escolas utilizamos a biblioteca e a sala de aula como espaços de pesquisa e reuniões.

2. A investigação qualitativa é descritiva. Os dados recolhidos são as palavras ou imagens e não números interpretativos. A pesquisa foi desenvolvida pelos trabalhos dos professores ao realizar, por escrito, os elementos curriculares para $\mathrm{o}$ andamento do trabalho pedagógico, às aulas e às atividades dos alunos. Por meio dos questionários, conhecemos os nossos sujeitos da pesquisa.

3. Interessam-se mais pelo processo do que simplesmente pelos resultados ou produtos. A pesquisa se baseia na observação, nas reuniões e nos materiais 
recolhidos e como forma de desenvolver o trabalho na sala de aula (que será destrinchada mais adiante).

4. Busca-se analisar os seus dados de forma indutiva, ou seja, desenvolvendo dentro do trabalho, uma pesquisa de percepção e conhecimento dos agentes envolvidos no processo. No caso, a ida as escolas e a convivência com os sujeitos pesquisados, nos quais refletimos a importância de uma produção e reflexão conjunta para o desenvolvimento da pesquisa;

5. O significado é de importância vital na abordagem qualitativa. Trabalhar com os professores é possibilitar não só a nós, mas também a eles, uma reflexão sobre os diferentes sujeitos e objetos do conhecimento e suas inter-relações. Conseqüentemente, o significado só foi possível mediante as diversas reuniões nas quais observamos as diferentes abordagens de cada professor que compartilhou com a pesquisa, e seguida da reflexão contínua da sua prática docente para uma organização da suas atividades pedagógicas de Geografia.

Estas características nos orientaram no processo da pesquisa ao dinamizar a ação participativa de todos os envolvidos: os pesquisadores, professores, alunos e a escola, de forma que houvesse uma articulação entre a teoria e a prática para uma produção curricular que permitisse um envolvimento dos sujeitos e dos objetos do conhecimento escolar.

Enfocamos, a pesquisa-ação, porque o nosso trabalho foi orientado não só pela nossa ação, mas por todos os envolvidos que, direta ou indiretamente trabalharam no projeto, buscando uma articulação dos sujeitos como pesquisadores e mediadores do conhecimento, e não somente como "reprodutores".

A pesquisa-ação traz a possibilidade de uma ação efetiva entre o pesquisador e seu objeto não se limitando a uma pesquisa precisa, mas permitindo aos envolvidos "fazerem", "dizerem" algo. A ação é um movimento duplo, e à medida que se torna significativa ao processo escolar, não é só executada pelo pesquisador, mas por todos os envolvidos na pesquisa. Segundo Thiollent (2007), esta tem alguns aspectos importantes:

a) há uma ampla e explícita interação entre pesquisadores e pessoas implicadas na situação investigada; 
b) desta interação resulta a ordem de prioridade dos problemas a serem pesquisados e soluções a serem encaminhadas sob forma de ação concreta;

c) o objeto de investigação não é constituído pelas pessoas e sim pela situação social e pelos problemas de diferentes naturezas encontrados nesta situação;

d) o objetivo da pesquisa-ação consiste em resolver ou, pelo menos, em esclarecer os problemas da situação observada;

e) há, durante o processo, um acompanhamento das decisões, das ações e de toda a atividade intencional dos atores da situação;

f) a pesquisa não se limita a uma forma de ação (risco de ativismo): pretendese aumentar o conhecimento dos pesquisadores e o conhecimento ou "nível de consciência" das pessoas e grupos considerados.

Estes aspectos possibilitam-nos pensar no desenvolvimento de uma pesquisa, principalmente, porque se deseja manter um diálogo aberto entre o pesquisador e os sujeitos buscando por possíveis soluções, repensando as práticas efetivas na sala de aula. Por isso, repensar o currículo de Geografia leva-nos a debater sobre a conjuntura social do aluno, da escola e da sociedade, para que a disciplina se torne um "elo" na busca da compreensão dessa sociedade, e conseqüentemente, move o aluno à percepção e observação do espaço em que vive.

Utiliza-se a pesquisa-ação como meio de articular os trabalhos entre os pesquisadores e os sujeitos/objetos de pesquisa a fim de mostrar a importância de se produzir, "agir" sobre o conhecimento, possibilitando, desta forma, a mudança de atitudes nos envolvidos da pesquisa. Organiza uma prática efetiva dentro do próprio ambiente escolar, no caso, dos professores e dos alunos que percebem a necessidade de construir ações que mobilizassem a dinâmica do ambiente escolar, em busca de transformações. A discussão entre o pesquisador e o sujeito da pesquisa promove condições no movimento desse grupo na tentativa de romper com a dicotomia entre objeto e sujeito, passando a ser, efetivamente, o pesquisador/sujeito das ações. Desse modo, a contribuição da pesquisa-ação é fundamental para que ocorra esse movimento, uma vez que o sujeito se torna pesquisador. Thiollent (2007) situa a pesquisa-ação na escola ao mencionar que:

"Com a orientação metodológica da pesquisa-ação, os pesquisadores em educação estariam em condição de produzir informações e 
conhecimentos de uso mais efetivo, inclusive ao nível pedagógico. Tal orientação contribuiria para o esclarecimento das microssituações escolares e para a definição de objetivos e ação pedagógica e de transformações mais abrangentes" Thiollent (2007: 81).

A importância da pesquisa-ação como metodologia de trabalho permite a construção de conhecimento de todas as partes da pesquisa, o pensar e a reflexão dos objetos que estão em volta e a melhoria social e educativa dos sujeitos. A pesquisa-ação é uma metodologia dinâmica e ativa, os agentes sempre estão em processo de ação, de construção, de produção, por isso a dificuldade de sistematizá-la, uma vez que, o pesquisador, os sujeitos e o objeto se inter-relacionam.

Fiorentini (2004) nos traz contribuições muito importantes para o entendimento da pesquisa-ação no ambiente escolar. Ao trabalhar com os professores de Matemática em Campinas, discute que o objetivo central dessa metodologia de pesquisa é promover e valorizar o trabalho docente, fazendo-os refletir sobre sua atuação como mediadores do conhecimento, ao analisar a necessidade de o professor se tornar $o$ sujeito/pesquisador do trabalho e não um mero reprodutor. Concordamos com o autor, quando ele argumenta:

"Embora possamos considerar a pesquisa-ação como uma técnica especial de coleta de informações, ela também pode ser vista como uma modalidade de pesquisa que torna o participante da ação um pesquisador de sua própria prática e o pesquisador um participante que intervém nos rumos da ação, orientado pela pesquisa que realiza. Acreditamos que esse é o principal sentido da pesquisa-ação. E, em que pese o sufixo 'ação', a pesquisa-ação também deve ser concebida como um processo investigativo intencionado, planejado e sistemático de investigar a prática”. Fiorentini (2004: 70-71).

Seguindo a mesma linha que o autor citado, Silva e Silva (1986) em seu livro Refletindo a pesquisa participante argumenta como Thiollent (1985) trabalha a relação da pesquisa-ação. Segundo a autora, essa metodologia promove uma ação coletiva entre o sujeito, o pesquisador e o objeto com o propósito de transformar em todos os aspectos os envolvidos, sendo que o sujeito acaba se tornando também o pesquisador do processo, por isso, a questão da ação, do movimento dos participantes. O sujeito passa a ser tanto passivo, como agente ativo na construção do conhecimento, possibilitando mudanças em sua atuação no ambiente. 
A autora salienta que nessa metodologia da educação os modos de intervenção são múltiplos, uma vez que no ambiente escolar, o trabalho é com professores, alunos, comunidades externa e interna, com o conhecimento, construindo várias relações no movimento dentro da pesquisa.

Partindo-se desta perspectiva tratada pela pesquisa-ação, relataremos a metodologia em etapas: a primeira realizada no período de (maio a dezembro de 2006) e a segunda realizada de (abril a agosto de 2007):

\section{$1^{a}$ Parte da pesquisa:}

$1^{\text {a }}$ etapa - Observação e reconhecimento das escolas, dos professores, dos alunos e das aulas;

$2^{\mathrm{a}}$ etapa - Aplicação do questionário com os professores;

$3^{\text {a }}$ etapa - Avaliação do questionário dos alunos pelos professores;

$4^{\text {a }}$ etapa - Análise dos questionários;

$5^{\text {a }}$ etapa - Preparação de reuniões com os professores: 10 (dez) reuniões para discussão de três textos e organização de uma proposta curricular de Geografia no ensino fundamental;

$6^{\text {a }}$ etapa - Análise dos dados recolhidos com redação final do exame de qualificação.

$7^{\text {a }}$ etapa - Pesquisa no NUDOM (Núcleo de Documentos) do Colégio Pedro II.

Na primeira etapa, a observação, é fundamental para a compreensão de como um determinado grupo ou sujeito desenvolve suas atividades, principalmente na pesquisa-ação que possibilita um trabalho livre. No caso a observação do nosso objeto de estudo e seu local, a escola, na qual existe uma relação social, educativa, histórica e espacial. Por isso, a preocupação de observá-la, principalmente o desenvolvimento das aulas dos docentes e das atividades realizadas pelos alunos, para percebermos os conteúdos ministrados em aulas e como os elementos curriculares entraram na sua prática pedagógica, as mudanças ocorridas na prática dos professores como no modo de analisar os alunos. Conhecemos também o espaço físico da escola, pois a utilização dos espaços existentes faz parte dos aspectos curriculares e da prática dos professores.

$\mathrm{Na}$ segunda etapa, realizamos a aplicação dos questionários para os professores (página 253), para conhecermos a formação e o trabalho deles. 
$\mathrm{Na}$ terceira etapa, os professores analisaram os questionários dos alunos para verificarem se as perguntas estavam de acordo e se gostariam de acrescentar mais alguma (página 255). Após isso, foi recolhido o questionário dos alunos (os professores avaliaram as perguntas), dessa maneira conhecemos um pouco sobre o tipo de aluno, o que gostam de fazer, como entendem a escola e, principalmente, a Geografia.

Na quarta etapa, a análise dos dados do questionário dos professores, que trouxe questões importantes para o desenvolvimento e compreensão do tipo de sujeito que atua na pesquisa, bem como a sua formação e seu conhecimento.

Na quinta etapa concentramo-nos na preparação de 10 (dez) reuniões com o corpo docente das escolas, nas quais discutimos três textos básicos sobre organização dos elementos curriculares de Geografia no ensino fundamental. Os textos lidos foram sobre currículo, o currículo geográfico e os conteúdos (no qual debatemos o processo de ensino-aprendizagem). Além de outros textos dos mesmos assuntos que os professores leram para compreensão da discussão sobre o currículo.

Os textos dos três autores escolhidos tratam, na primeira parte da pesquisa, do processo de construção curricular numa perspectiva dos componentes do currículo, o segundo aborda especificamente a Geografia, e o último foca a relação dos conteúdos em si e sua inter-relação. Houve outros temas de apoio, mas estes três foram escolhidos para uma discussão conjunta. As reuniões se realizarem da seguinte forma:

$1^{\mathrm{a}}$ reunião - Apresentação do projeto a ser desenvolvido: algumas considerações sobre currículo e um breve histórico do currículo de geografia;

$2^{\mathrm{a}}$ reunião - Discussão sobre a leitura do texto: COLL, César. Psicologia e currículo: uma aproximação psicopedagógica a elaboração do currículo escolar. São Paulo: Ática, 1999. 4a . ed., 65-152 p. e a solicitação de um esboço de cada professor da forma como deveria ser o currículo de Geografia.

$3^{\mathrm{a}}$ reunião - A continuação da discussão do texto de Coll (1996) e a escrita dos esboços sobre currículo.

$4^{\mathrm{a}}$ reunião - Discussão sobre texto: CAVALCANTI, Lana de Souza. Propostas curriculares de Geografia no Ensino: algumas referências de análise. In: Associação dos Geógrafos Brasileiros. As transformações no mundo da Educação: Geografia, Ensino e 
Responsabilidade social. São Paulo: AGB - Terra Livre, no. 14 jan./jul. 1999. 111-128 p.

$5^{\text {a }}$ reunião - A continuação do debate do texto de Cavalcanti (1999).

$6^{\text {a }}$ reunião - Discussão de alguns procedimentos de elaboração dos elementos curriculares: Objetivos, competências e habilidades, conceitos.

$7^{\mathrm{a}}$ reunião - Continuidade do debate da construção dos elementos curriculares.

$8^{\mathrm{a}}$ reunião - Continuidade da construção dos elementos curriculares com o debate da importância dos materiais e recursos didáticos e da avaliação e uma leitura do texto: ZABALA, Antoni. Os materiais curriculares e outros recursos didáticos. IN: A Prática Educativa: como ensinar. Editora Artmed, 1999. 2 ed. 167-194 p.

$9^{\mathrm{a}}$ e $10^{\mathrm{a}}$ reuniões - Continuidade da construção dos elementos curriculares: as escolhas dos conteúdos a serem trabalhos nas séries do Ensino Fundamental Ciclo II.

$\mathrm{Na}$ sexta etapa, realizamos a redação final da construção dos elementos curriculares pelos professores.

Na sétima etapa, concomitantemente com os trabalhos realizados, a pesquisa no NUDOM (Núcleo de Documentos) do Colégio Pedro II localizado na cidade do Rio de Janeiro, seis currículos de Geografia: 1850, 1898, 1931, 1951, 1982 e 1990. O objetivo foi fazer um resgate da história curricular da Geografia por meio do primeiro colégio do Brasil a ter um currículo oficial, percebendo como eram descritos. Os currículos eram "impostos" e vistos como uma "transmissão de conteúdos pelos professores". Além disso, esse resgate nos possibilita avaliar também o desenvolvimento dos elementos curriculares dos professores, pois há uma herança dos conhecimentos passados que agregam na história curricular, na prática de ensino e da atuação do docente na escola.

\section{$2^{a}$ Parte da pesquisa:}

$1^{a}$ etapa - Aplicação dos questionários aos alunos;

$2^{a}$ etapa - Verificação da aplicação dos elementos curriculares com os materiais produzidos pelos alunos e os planos de aulas dos professores; 
$3^{a}$ etapa - Reuniões com os professores;

$4^{a}$ etapa - Análise final e redação da dissertação.

A primeira etapa da segunda parte da pesquisa começou em meados de abril, momento da aplicação dos questionários para os alunos.

$\mathrm{Na}$ segunda etapa, nos meses de maio, julho, julho (recesso escolar) e agosto, observação e análise, dos elementos curriculares executados pelos professores. Sendo assim, assistimos a aplicação dos planos de aulas dos professores (e solicitando os planos de aulas) com a preocupação de avaliar as possíveis mudanças no comportamento tanto deles como dos alunos. Além disso, recolhemos e analisamos as atividades desenvolvidas pelos professores e pelos alunos, com a intenção de verificar se as atividades associavam os conteúdos geográficos à realidade.

$\mathrm{Na}$ terceira etapa, demos continuidade às reuniões para o debate de textos. Primeiramente, discutimos como repercutiu o trabalho desenvolvido, depois discutimos alguns materiais sobre a cidade de São Paulo e depois, debates com dois textos para ajudar os professores a pensar sobre uma proposta curricular descrita por uma professora de Geografia em sua pesquisa, e outro texto que tratava da atuação do professor na aprendizagem.

$1^{a}$ reunião - Debate sobre os elementos curriculares;

$2^{\mathrm{a}}$ reunião - Continuidade do debate;

$3^{\text {a }}$ reunião - Material para os trabalhos dos docentes na sala de aula;

$4^{\mathrm{a}}$ reunião - Leitura e discussão do texto de SPYER, Márcia Resende. Espaço real: análise das "histórias de vida". In: A geografia do aluno trabalhador: caminhos para uma prática de ensino. Belo Horizonte: Ed. Loyola, 1986. 131-162 p;

$5^{\mathrm{a}}$ reunião - Continuidade da discussão do texto de Spyer (1986);

$6^{\mathrm{a}}$ reunião - Continuidade da discussão do texto de Spyer (1986);

$7^{\mathrm{a}}$ reunião - Debate do texto CASTELLAR, Sônia. A psicogenética e a aprendizagem de Geografia. IN: __.Educação Geográfica: teorias e práticas docentes. São Paulo: Contexto, 2005. 66-78 p. (Geousp: Novas Abordagens)

Na quarta etapa do trabalho, mediante a organização da nossa metodologia de pesquisa, desenvolvemos a análise de todo o material para nossa redação final da dissertação de mestrado. O momento da escolha e do processo para a continuação da 
pesquisa nos mostra a forma de conduzi-la, a fim de dividirmos o capítulo de acordo com a concepção teórica, na busca dos autores que embasaram a pesquisa, bem como a parte empírica que nos enriqueceu os questionamentos, a prática e a ação do trabalho. 


\section{CAPÍTULO I}

\section{CONHECENDO OS AGENTES DA PRODUÇÃO DOS ELEMENTOS CURRICULARES DO ENSINO DE GEOGRAFIA: AS ESCOLAS, OS PROFESSORES E OS ALUNOS}

“A preparação das crianças e jovens para a participação ativa na vida social é o objetivo mais imediato da escola pública. Esse objetivo é atingido pela instrução e ensino, tarefas que caracterizam o trabalho do professor.

A instrução proporciona o domínio dos conhecimentos sistematizados e promove o desenvolvimento das capacidades intelectuais dos alunos"

Libâneo (1994:33) 


\section{1. As escolas: os espaços de mediação entre o docente, o aluno e o saber para a produção curricular do conhecimento do cotidiano}

A pesquisa escolar sempre é um ponto interessante, pois agrega não só o professor e o aluno, mas a escola como um espaço importante nessa construção do conhecimento. Por mais que os espaços de aprendizagem sejam variados, a escola representa o espaço "oficial", pois nela implica a construção social, política e educacional como regimentos que movem o cotidiano nesse espaço, bem como a organização de lugares para que os professores utilizem os materiais existentes nela.

Espaço, que se caracteriza de contradições sociais criadas pela relação da sociedade e, ao mesmo tempo, pelas relações que são manifestadas pelos teóricos para a organização de um currículo que privilegie não só a produção, mas também a vivência do aluno, já que a escola também é um lugar das relações afetivas dos alunos, ou seja, no qual ele vive seu momento de alegria, de descontração, de brincadeiras, de comunhão com seus colegas.

A escola é um espaço sócio-cultural onde vários indivíduos freqüentam-na com características sociais, étnicas, econômicas, culturais, diversas. É o "aluno" e o "professor" que vivenciam o cotidiano, no qual o conhecimento é sistematizado e organizado. É o lugar em que eles mantêm relações afetivas e profissionais com os outros. Entender a escola enquanto espaço sócio-cultural significa:

"Compreendê-la na ótica cultural, sob um olhar mais denso que leva em conta a dimensão do dinamismo, do fazer-se cotidiano, levado a efeito por homens e mulheres, trabalhadores e trabalhadoras, negros e brancos, adultos e adolescentes, enfim, alunos e professores, seres humanos concretos, sujeitos sociais e históricos, presentes na história, atores na história. Falar da escola como espaço sócio-cultural implica, assim, resgatar o papel dos sujeitos na trama social que a constitui, enquanto instituição” Dayrel (1996:137).

A diversidade cultural na escola é grande já que abarca as experiências de vidas diferenciadas, o que permite que esta se torne um lugar com uma multiplicidade de 
sentido $^{1}$. Ela é ao mesmo tempo um espaço de relações sociais entre a comunidade interna e externa, como um espaço afetivo, de trabalho dos professores, dos coordenadores, dos diretores e dos outros funcionários; mas também político, pois é gerenciado pelo poder público, no entanto, antes de tudo, um espaço educativo. Assim, Dayrel comenta:

"Dizer que a escola é polissêmica implica levar em conta que seu espaço, seus tempos, suas relações podem estar sendo significados de forma diferenciada, tanto pelos alunos, quanto pelos professores, dependendo de cultura e projeto dos diversos grupos sociais nela existentes" (id, ibid: 1996: 144).

Conforme Dayrel, a escola sendo um espaço cultural e educativo abarca diferentes formas de relações sociais que se misturam e convivem nesse. Os sujeitos, os quais convivem no ambiente escolar, têm necessidades específicas e modos de vidas diferentes, buscam na escola uma "relação social", um "conhecimento", uma "inclusão na sociedade", independente de raça, trabalho ou religião, isto faz com a que escola se torne um espaço contraditório.

A escola reformula seus valores, principalmente a escola pública, quando se torna mais um dos lócus de disputas políticas do que de produção efetiva de conhecimento. Cada vez mais a escola se torna um palco de estratégias no qual projetos devem ser desenvolvidos para aumentar os pontos da escola frente as suas diretorias, pelo menos dentro do estado de São Paulo.

É importante frisar que a escola pública é um espaço político, social e ideológico, e que nesse processo do sistema atual capitalista, desenvolve uma função muito efetiva no processo de democracia e cidadania do ser humano, a busca de um ensino que privilegie não só o conhecimento escolar para a vida social, mas também valores, atitudes e que os alunos transponham os conhecimentos para as áreas de trabalho nesse mundo capitalista que necessita de um ambiente no qual o processo de aprendizagem siga regras, formas e funções que permita uma organização sistematizada.

Um espaço importante, porque sua gestão parte da visão que cada governo tem sobre educação, da formação dos diretores, vice-diretores, coordenadores, corpo

\footnotetext{
${ }^{1}$ Dayrel, J. (1996) argumenta que a escola não é só uma instituição com o objetivo de adquirir conhecimento, mas um espaço de festas, de encontros, de reuniões, de manifestações culturais e sociais, de vivência dos alunos, de trabalho, por isso a multiplicidade de sentido.
} 
docente, outros funcionários e dos próprios discentes que têm para organizarem as partes administrativas, pedagógicas, sociais, culturais, financeiras ao sustentarem a relação esperada: o processo de aprendizagem do aluno, ou seja, a sociabilização do saber mediante também as relações culturais que este carrega consigo. Isto implica que todos estão envolvidos direta ou indiretamente nas relações cotidianas da escola, e que todo o processo de ensino, também está sujeito às mudanças na estrutura dos elementos curriculares que os professores pensaram ao longo de seus planejamentos.

Por isso, é importante dizer que muitas vezes, os trabalhos dos professores foram afetados pelo envolvimento da escola em diversas atividades que fazem parte da sua rotina e outras que não. Essas mudanças freqüentes no calendário escolar acabam prejudicando todo planejamento, à medida que os docentes modificam as estratégias ou necessitam rever seu trabalho para organizar suas aulas.

É nesse ambiente que o processo de aprendizagem acontece promovendo a diversidade do saber, produzindo e estimulando os professores, os alunos e os outros funcionários nas atividades educativas que contribuem para o crescimento pessoal e coletivo desses agentes na sociedade. É um lugar onde os saberes científicos da Geografia contribuem para o processo do conhecimento educativo, por isso:

"A escola é um lugar de encontro de culturas, de saberes, de saberes científicos e de saberes cotidianos, ainda que o seu trabalho tenha como referência básica os saberes científicos. A escola lida com costumes, seja no interior da sala de aula, seja nos demais espaços escolares. E a Geografia Escolar é uma das mediações por meio das quais esse encontro e confronto se dão" Cavalcanti (1999: 115).

Cavalcanti corrobora relatando as múltiplas representações da escola e como lidar com seus diferentes espaços e suas diferentes culturas agregadas a ela, nos quais os valores culturais, científicos e sociais permeiam esse universo polissêmico e que abrangem também as disciplinas que contemplam a grade curricular de ensino. No caso da Geografia, uma ciência mediadora das relações sócio-espaciais existentes no mundo e que se estabelecem também no ambiente escolar.

Sendo assim, a escolha da pesquisa em duas escolas públicas estaduais no município de São Paulo é um esforço dos professores em construir uma disciplina que permita a leitura do espaço geográfico da realidade vivida do aluno. 


\subsection{A descrição das escolas estudadas:}

A descrição da arquitetura e a localidade das escolas, bem como da gestão, são formas de mostrar sua contextualização espacial e sua organização. As escolas são estruturadas a partir de uma organização gestora que direciona as leis vigentes do governo, das diretorias responsáveis, do calendário escolar, dos funcionários existentes nela, da grade curricular, da função pedagógica, social, política, administrativa para que se possa acontecer o processo de ensino e aprendizagem.

Por isso, é importante dizer, que a construção dos elementos curriculares realizada pelos docentes das duas escolas, apesar de ser uma construção coletiva dos professores de geografia, está imbricada com o próprio currículo escolar. E compreender a dinâmica da própria estrutura da escola, possibilita-lhes desenvolver seus trabalhos.

Isso está agregado pelos espaços que têm seu significado: o pátio, a cantina, a sala dos professores, a sala de aula, os corredores... esses espaços são locais onde acontecem a produção, a percepção e a contribuição para o desenvolvimento do processo do conhecimento dos alunos.

Além disso, a função de cada um dentro da escola é importante para que tudo ocorra no processo organizacional da escola, como a utilização dos espaços, as ações dos docentes e dos discentes nessa produção cultural e educativa.

Para a pesquisa foram selecionadas duas escolas que caracterizaremos a seguir.

\subsubsection{A Escola da Zona Leste de São Paulo}

A Escola se localiza no Bairro Jardim Redil, Distrito de Itaquera, Zona Leste, a porção oriental do município de São Paulo. O nome Itaquera é de origem tupi e quer dizer "pedra dura". A data de fundação do Bairro ainda é uma incógnita. A primeira referência de que se tem notícia é de 1686, quando o nome aparece em uma Carta de Sesmaria. A povoação de Itaquera começa a se desenvolver a partir da inauguração da estação de trem local, no dia 6 de novembro de 1875, data escolhida pela comunidade como a do aniversário, apesar de toda a polêmica em torno da verdadeira idade. $\mathrm{O}$ progresso foi chegando de forma desordenada e na esteira da industrialização paulista, o 
povoado tranqüilo de Caguassu se transformou na grande Itaquera de hoje, uma área da periferia da cidade. Nesta conjuntura espacial e histórica se situa a referida escola. ${ }^{2}$

A estrutura espacial da escola é dividida da seguinte maneira: existem vinte e duas salas de aula, quatro laboratórios: (Biologia, Educação Artística, Química e uma está em manutenção), um pátio grande, quadra de esportes, biblioteca, sala de vídeo, teatro, laboratório de informática, sala de professores, sala de inspetores, sala dos coordenadores, sala para atendimento aos pais, sala dos vice-diretores, sala do diretor, secretaria, sala do grêmio, cantina e cozinha. Abaixo fotos da escola.

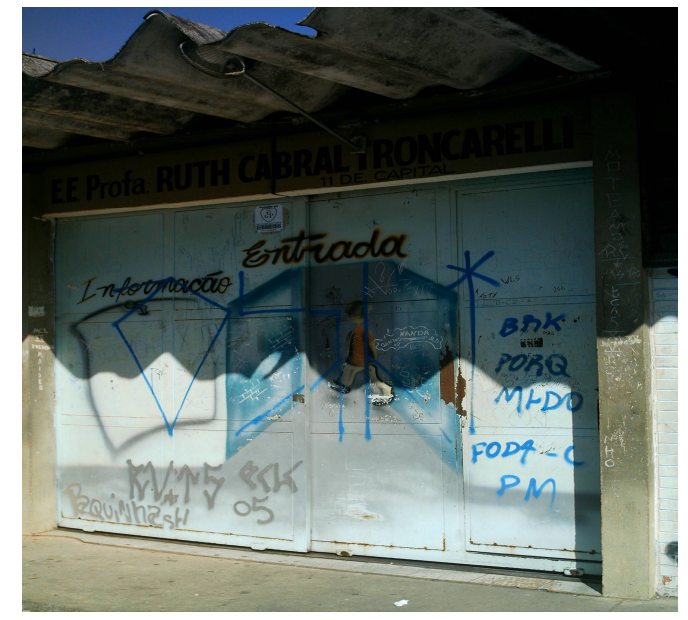

Foto 1: Entrada dos alunos da Escola

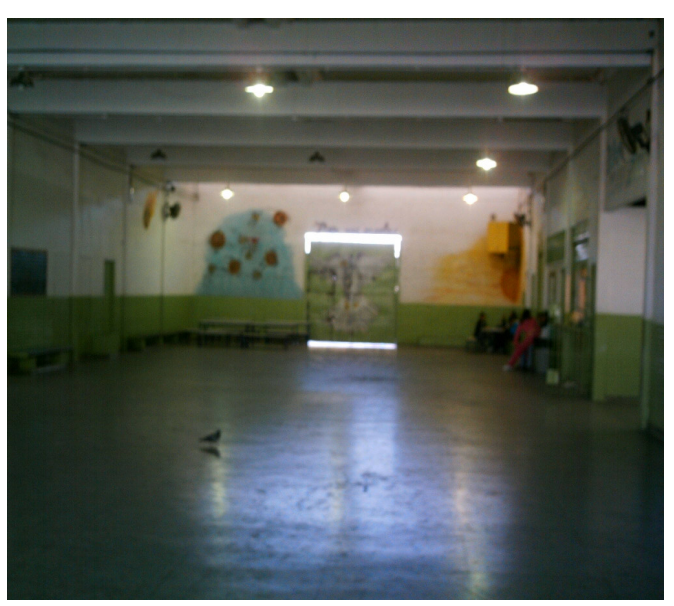

Foto 3: Pátio

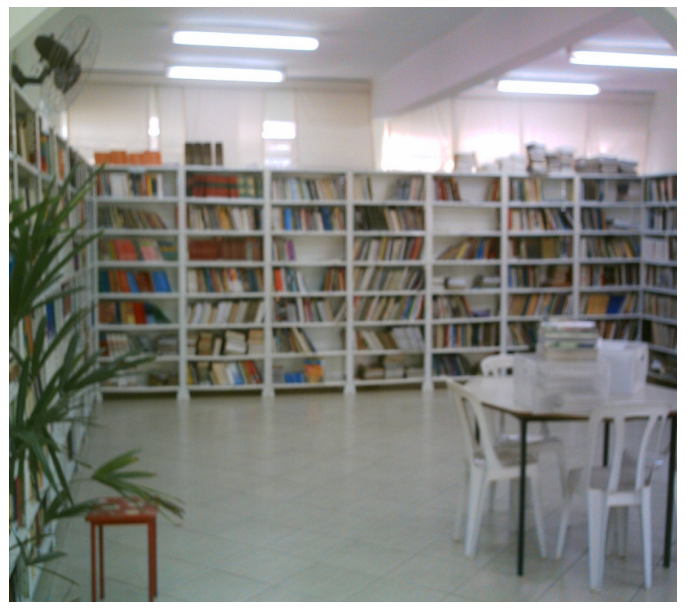

Foto 2: Biblioteca

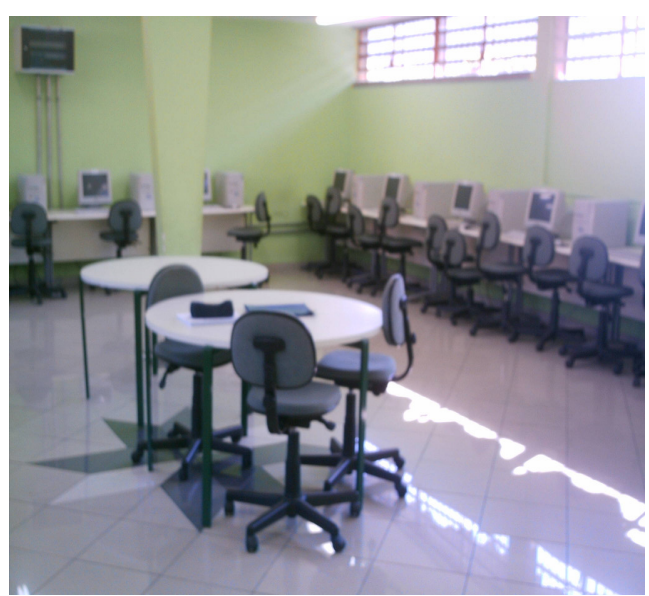

Foto 4: Sala de informática

\footnotetext{
${ }^{2}$ Algumas informações sobre o Distrito de Itaquera se encontram no site da Prefeitura do Município de São Paulo. www.prefeitura.sp.gov.br
} 


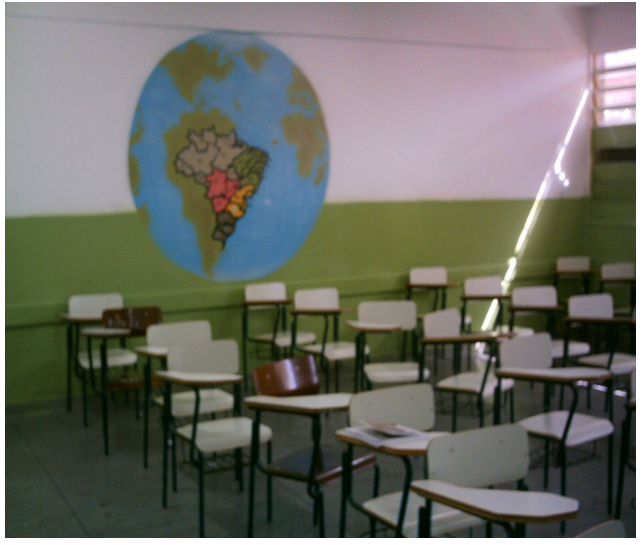

Foto 5: Sala de aula

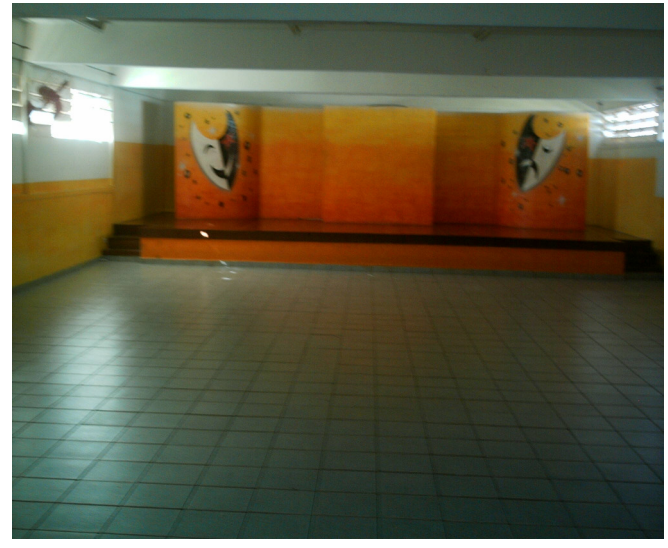

Foto 6: Teatro

A escola funciona com a existência de: três turnos (manhã, tarde e noite) Ensino Fundamental II e Ensino Médio. Trabalha com vários projetos como Sexualidade, Informática, Escola do Possível, entre outros. O último projeto citado é específico da escola, porque as outras são externas, caracteriza-se na tentativa do corpo docente e da direção de realizar atividades escolares no qual envolva todos os espaços existentes para desenvolver um processo educativo no qual as disciplinas se interrelacionem, e que os docentes produzam atividades que motivem os alunos em suas habilidades e compreendam que a aprendizagem não se dá especificamente na sala de aula, mas em toda parte da escola.

É uma tentativa de romper com uma estrutura rígida, possibilitando também mudanças metodológicas e didáticas do professor, e mudanças na estrutura organizacional da própria escola, uma vez que há uma oportunidade da participação mais efetiva do aluno nas suas escolhas. A idéia é, de cada vez mais, dar novas responsabilidades aos alunos, fazendo-os compreender o significado de valores como o respeito, estimulando atitudes e o gosto pelo aprender. Além do incentivo para que estes sejam mais autônomos e busquem na pesquisa uma forma de aprendizagem.

Todos estão engajados neste projeto para transformar a escola burocrática em uma escola viva, com perspectivas para aqueles que estudam nela. A Geografia contribui já que o aluno deve pensar espacialmente como ele se organiza e se insere dentro dessa realidade, e compreender como os objetos se organizam nessa dinâmica. $\mathrm{O}$ professor deve estar consciente da sua formação e da sua relevância na mudança de comportamento dentro da escola. 
Para a pesquisa, trabalhamos com o Ensino Fundamental na área de Geografia com três professoras que desenvolveram os elementos curriculares da disciplina.

\subsubsection{A escola da Zona Sul de São Paulo}

A outra escola pesquisada é a "B" localizada no bairro São João Clímaco, Distrito do Ipiranga, Zona Sul de São Paulo (próxima à Comunidade Heliópolis). Este se localiza na região sudeste do município, cujo nome foi extraído do córrego que o corta, e cujo nome significa, em tupi-guarani, rio vermelho, devido às águas barrentas do riacho. Neste bairro está localizado o Parque da Independência, local onde, segundo consta, o imperador D. Pedro I proclamou a independência do Brasil, além do Museu do Ipiranga, com arquitetura em estilo clássico, que guarda um grande número de relíquias do período colonial brasileiro, e do Museu de Zoologia. O distrito é servido pelas estações Ipiranga e Tamanduateí da Companhia Paulista de Trens Metropolitanos, e pela estação Alto do Ipiranga do metrô ${ }^{3}$.

A região próxima ao Rio Tamanduateí tinha características industriais, a ponto de que os bondes e ônibus que para lá se dirigiam tinham no letreiro o título Fábrica. A área próxima à Avenida Nazaré, por sua vez, denominada Alto do Ipiranga, era caracterizada por casarões de famílias abastadas e pela classe média que trabalhava nas fábricas ou em outros bairros de São Paulo

Outro fato importante, é que nele se encontra a maior "Favela" de São Paulo Heliópolis- o que sempre nos remete às questões dos problemas urbanos das metrópoles brasileiras: violência, falta de estrutura, tráfico, entre outros. Composto por 14 glebas (apartamentos feitos para os moradores que tinham casas de papelão), possui 100 mil habitantes e uma área de quase um milhão de metros quadrados. Apesar de ter status de bairro, todos ainda a chamam de Favela ou Comunidade do Heliópolis.

$\mathrm{Na}$ estrutura física da escola existem quinze salas de aula, um auditório (que no momento foi dividido em três partes: biblioteca, sala de vídeo e teatro), um pátio com quadra coberta e outra pequena descoberta, sala dos professores, da direção, dos vice-

\footnotetext{
3 Informações utilizadas do Distrito de Ipiranga acessar o site da Prefeitura de São Paulo. www.prefeitura.sp.gov.br
} 
diretores, uma sala de arquivo e a secretaria, uma pequenina sala que se tornou uma área para atendimento de desvios de comportamento com o psicólogo, uma sala de laboratório de informática (que não foi ainda montado por conta dos trâmites legais), cantina e cozinha. Abaixo fotos da escola.

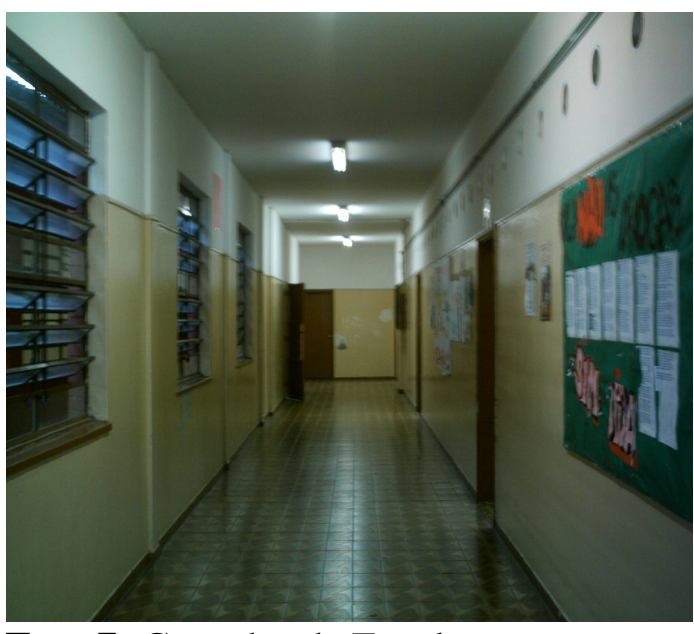

Foto 7: Corredor da Escola

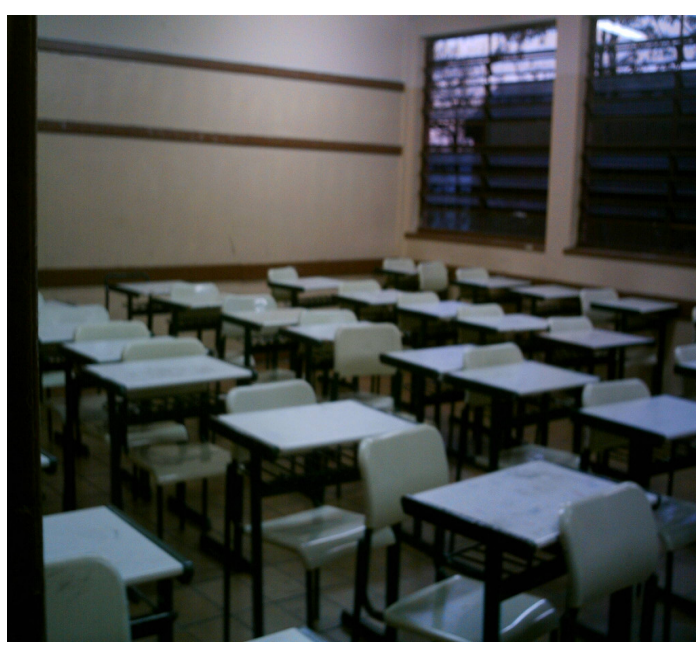

Foto 9: Sala de aula

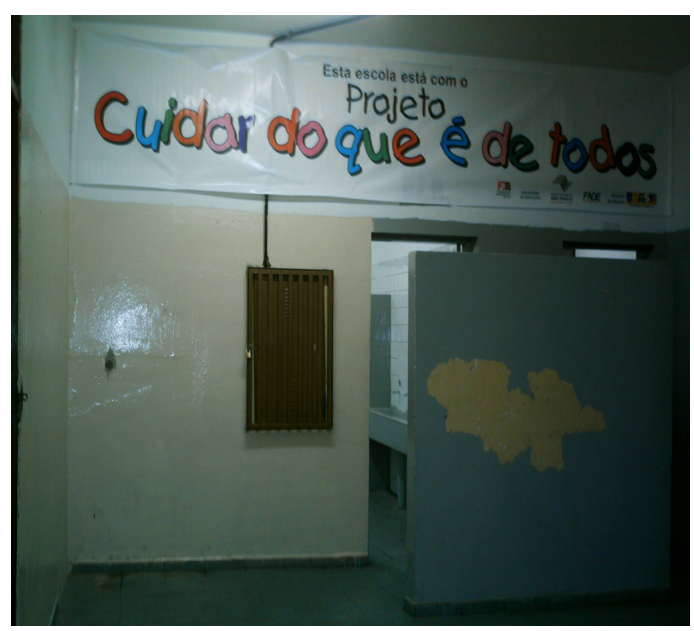

Foto 8: Banheiro da Escola

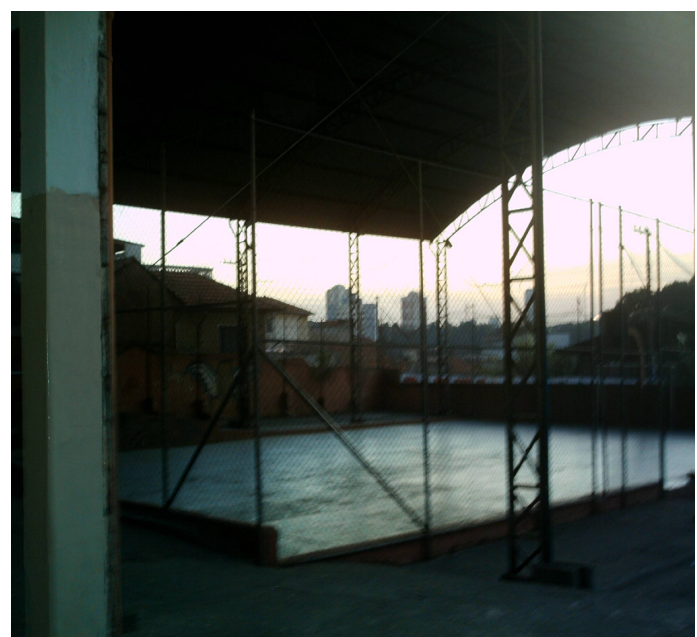

Foto 10: Quadra coberta da Escola

A escola funciona com a existência de: três turnos (manhã, tarde e noite) Ensino Fundamental II e Ensino Médio regular e Ensino Médio de Jovens e Adultos e seis professores de Geografia (nos quais três trabalharam na pesquisa).

A escola desenvolve os projetos que são enviados pela Secretaria de Educação: como Projeto Cuidar do que é de Todos e a cada semestre os professores têm que desenvolver com os alunos Projeto Temático específico de acordo com as áreas do conhecimento. Trabalhamos com três professores de geografia do Ensino Fundamental 
que se comprometeram com a pesquisa para repensar suas práticas e formular alguns elementos curriculares da Geografia na escola.

\section{Mapa com a localização das escolas:}

O mapa do município de São Paulo é dividido de acordo com os distritos, pois segundo a Secretaria de Planejamento urbano, dentro da lei de planejamento municipal, recolhe todos os dados de acordo com os distritos existentes, uma vez que a divisão por bairros seria extremamente difícil de visualização, já que cada distrito tem no mínimo 10 bairros. Então, colocamos os nomes dos distritos de cor distinta para indicar a localização de cada uma delas. Outro fato, é que dentro da própria lei não existe a divisão por Zonas (que não é uma divisão oficial, mas a secretaria utiliza-o somente para estudo). 


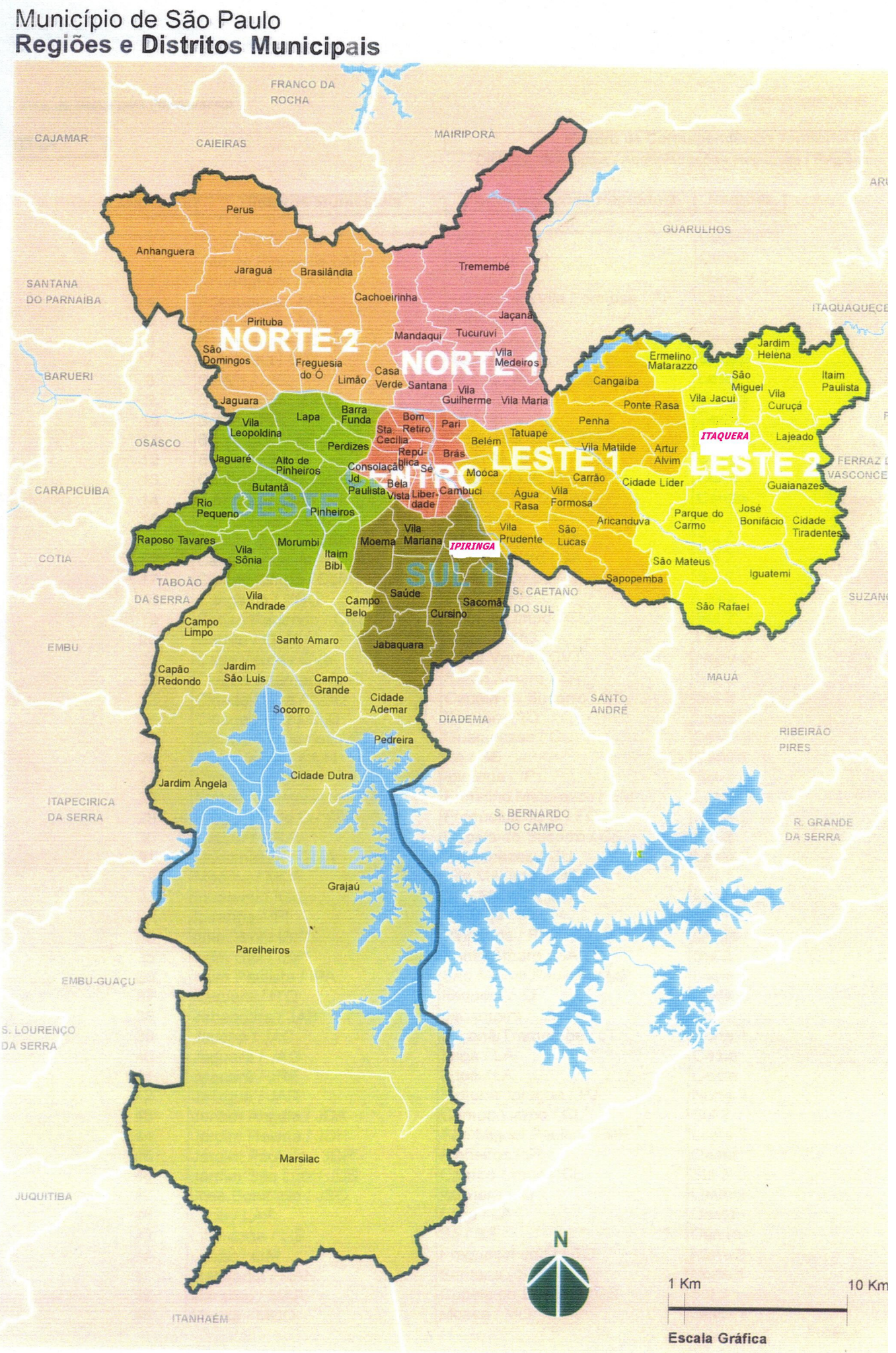




\subsection{A valorização dos agentes da construção do conhecimento do vivido: os professores e suas concepções}

A formação docente é um dos elementos importantes dentro das pesquisas voltadas para a Educação, porque sua prática está atrelada às mudanças conceituas e estruturais decorrentes das mudanças educacionais. Essa necessidade de se estar sempre estudando a prática docente permite que seja discutida sua valorização enquanto um profissional mediador do conhecimento.

A importância dessa formação está relacionada com a preparação do conhecimento pedagógico e do específico para que a aprendizagem, a didática, a metodologia e currículo que fazem parte do ensino escolar, não seja um simples "passar" do conteúdo, mas desenvolva no profissional o prazer de realizar seu trabalho possibilitando o progresso escolar do aluno. Desta forma, a necessidade deste professor está na reflexão sobre a sua prática e no estudo para que seu trabalho seja bem realizado.

De acordo com Sacristán (1995) o desenvolvimento profissional do professor se perpassa por quatro grandes campos:

1. O professor e a melhoria, ou a mudança, das condições de aprendizagem e das relações sociais na sala de aula;

2. O professor participando ativamente no desenvolvimento curricular, deixando de ser um mero consumidor;

3. O professor participando e alterando as condições da escola;

4. O professor participando na mudança do contexto extra-escolar.

Nestes quatro campos estão descritas questões como o professor mediador do conhecimento, um profissional analítico, avaliativo pode conduzir as relações sociais que se desenvolvem na escola possibilitando sua atuação, no trabalho de ensino e aprendizagem. Ele exerce a capacidade de melhorar as condições de seu ensino, sempre estando disposto a desenvolver o trabalho para mudar a dinâmica do processo de aprendizagem de seu aluno.

Além disso, o professor, consciente do seu papel de orientador do conhecimento, prepara-se para desenvolver outros papéis dentro do sistema escolar. Este pode 
participar da elaboração dos projetos políticos da escola e, principalmente, no desenvolvimento do currículo que conforme Arroyo (1999) é um processo direcionado de cima para baixo para ser consumido e seguido pelo professor, sem ao menos, ter um diálogo com este para saber qual a necessidade real do aluno e do trabalho daquele a quem deverá executar toda a tarefa.

A função social do professor pode ser definida segundo Sacristán (2000:67), "pelas necessidades sociais a que o sistema educativo deve dar resposta, as quais se encontram justificadas e mediatizadas pela linguagem técnica pedagógica”.

O professor organiza sua prática reflexiva e, a partir dela, agirá e desenvolverá suas funções. Deixará de lado a sua posição de "reprodutor" do conhecimento e dialogará com a teoria e a prática que o orientam; estruturando suas ações na orientação de observar, descrever, analisar e avaliar o processo construído que modificando seu modo de pensar e agir sobre o conhecimento.

A formação e prática docente estão interligadas com as necessidades que o sistema educativo gera em estruturar o conhecimento, para que esse mediador possa produzir uma práxis dentro e fora da escola, possibilitando um diálogo entre a teoria e a prática, por intermédio de uma formação consolidada, orientada e articulada em promover um senso crítico no fato de pensar os professores como profissionais "reflexivos".

Na perspectiva de Nóvoa (1995) a formação do professor não é construída por acumulação de diversas atividades, mas sim pelo trabalho de reflexão das práticas e de (re) construção permanente de sua identidade pessoal. O professor tem o "direito" de dialogar, de discutir, de criticar, de analisar e de avaliar todos os aspectos que ocorrem em sua profissão, sendo estimulado a pensar sua prática cotidiana. Visto também como um promotor de aprendizagens, ou seja, o qual organiza e prepara as atividades nas quais os alunos desenvolverão suas habilidades. Por isso, para Nóvoa (1995:25): “A formação deve estimular uma perspectiva crítico-refletiva, que forneça aos professores os meios de um pensamento autônomo e que facilite as dinâmicas de autoformação participada”.

Sendo assim, o professor autônomo, reflexivo, consciente da formação e do seu papel na escola possibilita a mudança e o rumo da escola em se organizar, para que desenvolva o processo de ensino e de aprendizagem que ocorre nessa e de outras questões que permeiam o processo do envolvimento escolar. 
Arroyo (1999) afirma que é fundamental que as pessoas encarregadas de decidirem sobre os rumos da educação permita que os professores desenvolvam os processos educativos, porque são profissionais da educação que teriam autoridade para organizar junto à comunidade interna e externa as mudanças no processo escolar. A liberdade deve ser dada aos professores, em criar novas práticas, em pensar no processo curricular que possibilite sua participação mais ativa no desenvolvimento do ensino e da aprendizagem. As secretarias devem fornecer equipamentos, materiais, melhores salários, formação continuada e tempo para que o professor estude e se capacite com o objetivo de inovar a metodologia e a didática presente em sala de aula. Então, conforme o autor:

"Qual seria, então, o papel dos que decidem? Um papel insubstituível, o de 'elaborar estratégias de educação deixando para os profissionais da escola o papel de fazer a educação. Dar condições materiais e pedagógicas para que os professores mudem as práticas, os currículos, os processos de avaliação, a organização pedagógica dos tempos e dos espaços. Criar equipes capazes de repensar e melhorar essas condições... Criar espaços de trabalho e reservar tempo de estudo e pesquisa para os professores, de modo que lhes seja possível inventar novas práticas... Deixar essas questões por conta dos professores. São suas questões. São suas tarefas". Arroyo (1999: 140-141).

O professor é um profissional que organiza sua atividade, e a interferência no realizar seu trabalho pode prejudicar o seu processo de criação. O professor que busca seu lugar no espaço escolar mostra que não é um fantoche, mas um ser pensante que conforme Giroux (1997) necessita de condições, de capacitação e de tempo para investir e realizar um trabalho de qualidade:

"Os intelectuais transformadores precisam desenvolver um discurso que una a linguagem da crítica e a linguagem da possibilidade, de forma que os educadores sociais reconheçam que podem promover mudanças. Desta maneira, eles devem se manifestar contra as injustiças econômicas, políticas e sociais dentro e fora das escolas". Giroux (1997: 163).

$\mathrm{O}$ autor ressalta a necessidade do professor promover, no processo educativo, a criatividade que estimule as transformações no cotidiano e traga uma compreensão das mazelas decorrentes da situação econômica, política e social da sociedade, permitindo que o conhecimento seja a possibilidade de avanço em todo âmbito educativo ou não. A missão dos intelectuais transformadores é possibilitar mudanças no pensar e agir dos 
alunos e das pessoas que estão no entorno, e façam-se reconhecer a importância de se manifestar nessa sociedade.

De acordo com Apple (2001) a consciência e a transformação da formação docente promovem na escola novas possibilidades de inovações que estruturaram toda ideologia política, cultural, social e pedagógica do currículo escolar. Investir no professor é admitir que este tenha condições de intervir construtiva e ativamente no contexto escolar.

O processo de ensino e de aprendizado pode tornar-se dinamizado para os alunos, quando o professor conhece as suas necessidades, sabe como é a sua comunidade, as possibilidades da escola, trabalhando em prol das coisas no qual ele acredita ser importante para o conhecimento de seus alunos. Mas, este trabalho depende do desempenho de todas as pessoas que trabalham por uma educação de qualidade. Assim:

"A mediação do professor ressalta o papel influente que este tem e a importância de sua formação cultural e profissional... Estes não são meros adaptadores dos currículos, sem que, através das introduções por eles realizadas dentro do próprio processo de desenvolvimento do currículo, se convertem em mediadores entre a cultura exterior e a cultura pedagógica da escola. O professor é, por ele, um agente decisivo para que o currículo real seja o projeto cultural desenvolvido nas condições objetivas, tal como as representa, e abaixo do crivo dos processos subjetivos através dos que se estende na ação". Sacristán (2000: 232).

O autor argumenta que o professor é um mediador do conhecimento, e como tal, não pode ser considerado mero reprodutor, pois a concretização do processo curricular depende da sua ação dentro da escola para que sejam alcançados os objetivos propostos no projeto educativo. Eles possibilitam a mediação entre a cultura do mundo e a relação cultural na escola, formulando situações de transformação no agir que permitam a transposição do conhecimento para a realidade vivida sem esquecer os conteúdos universais da Geografia.

A produção curricular não é só concretizada na sala de aula entre o professor e o aluno, mas também por todas as pessoas que trabalham na educação, buscando uma dinâmica, uma inovação da prática educativa e na concepção de uma estrutura de um currículo que permita o desenvolvimento do trabalho docente em articular a teoria e a prática.

Esse envolvimento do professor está em todos os campos de conhecimento: Ciências, Matemática, História, Geografia e etc. Particularmente iremos analisar o 
professor de Geografia que é um dos profissionais a contribuir na discussão de um novo pensar sobre o currículo, já que as aulas de Geografia (não só ela) permitem ao professor pensar a realidade vivida do aluno. A concepção conceitual dos temas básicos da disciplina (conceito de espaço, espaço vivido, lugar, território, paisagem, região e temas como urbanização, industrialização, as questões agrárias, os processos de transformação do meio físico e tantos outros) propicia a construção do conhecimento voltado para uma discussão da vida cotidiana.

O trabalho produzido pelos professores, trazendo a questão do cotidiano, possibilita às pessoas compreenderem como se produz o espaço em que elas vivem, ou seja, permite a elas enxergarem como o bairro, o município, o estado, o país se ordena, como o espaço foi modificado ao longo do tempo, a necessidade do ser humano em construir locais para trabalhar, para morar, para estudar, para se movimentar ordenadamente...

Neste mesmo movimento a linguagem cartográfica como referência base da Geografia possibilita o desenvolvimento de uma leitura, interpretação, análise, codificação, localização que permita ao aluno relacionar sua espacialidade aos mapas, compreendendo como ele e os objetos se estruturam em um determinado espaço e como lemos essa linguagem. Os mapas são utilizados como instrumentos para organização de estratégias militares, uso comercial de empresas, de uso industrial para criação e organização do mercado consumidor, e outras utilidades.

A possibilidade do professor de Geografia construir e produzir uma proposta curricular possibitar-lhe-á orientar e organizar os conteúdos geográficos necessários aos conhecimentos os quais contemplarão as diversas práticas importantes para desenvolver no aluno o senso crítico sobre seu cotidiano. Cavalcanti (1995), Rocha (2000) analisam como a realidade vivida pelo aluno pode ser estruturada nas discussões em aula, numa dialética, pois o espaço se apresenta de múltiplas formas e territorialidades.

Os elementos curriculares têm como um dos principais aspectos a organização dos conteúdos, porque, por meio deles o professor formula as unidades didáticas necessárias para que o aluno compreenda o objeto geográfico: estudar a organização e a representação espacial da sociedade em que ele também é o agente. Neste contexto, os conteúdos trabalhados pelo professor possibilitam ao aluno refletir e compreender a sua própria espacialização e a organização da sociedade e de seu cotidiano.

A escolha dos conteúdos pelo professor é também feita por sua concepção de geografia que é estabelecida por uma determinada época, num período histórico 
vivenciados pelos agentes desse processo. Os tipos de conteúdos podem permanecer no currículo dependendo do interesse e do contexto no qual a sociedade naquele momento está inserida. Sacristán (1998:150) menciona a importância de se pensar os conteúdos conforme diz: "Os conteúdos compreendem todas as aprendizagens que os alunos/as devem alcançar para progredir nas direções que marcam os fins da educação numa etapa da escolarização”.

Os conteúdos se tornam um instrumento massificador com o objetivo de promover uma concepção ideológica dentro do sistema escolar, e a escolha é de acordo com os interesses e concepções vigentes da época. Trabalhar o conteúdo na escola é, ao nosso entender, o meio para desenvolver a capacidade do aluno na compreensão de sua realidade por meio de um sistema organizado, com valores científicos e orientadores que permitirá a ele construir sua capacidade de ler o mundo a sua volta, sua relação entre o próximo/distante e compreender historicamente as suas transformações.

Selecionar os conteúdos é uma tarefa difícil para os professores, uma vez que várias são as questões que se pode contemplar, principalmente na Geografia, uma disciplina que trabalha as relações espaciais da organização da sociedade e que diferem cultural, social, política e economicamente.

Pensar nos conteúdos não somente como elemento da disciplina em si, mas como nos permitirão desenvolver outras capacidades importantes para avaliação e progressão do aluno nas relações afetivas, nas interpessoais, nas sociais. Deste modo, a construção e percepção do tipo de conteúdo que desejamos mediar se organiza em outra lógica, de outra maneira. Concordamos com Zabala (1999) quando menciona que:

\begin{abstract}
"Devemos nos desprender desta leitura restrita do termo "conteúdo" e entendê-lo como tudo quanto se tem que aprender para alcançar determinados objetivos que não apenas abrangem as capacidades cognitivas, como também incluem as demais capacidades. Deste modo, os conteúdos de aprendizagem não se reduzem unicamente às contribuições das disciplinas ou matérias tradicionais. Portanto, também serão conteúdos de aprendizagem todos aqueles que possibilitem o desenvolvimento das capacidades motoras, afetivas, de relação interpessoal e inserção social". Zabala (1999:30).
\end{abstract}

A abordagem de conteúdos neste sentido trará uma visão mais aberta da importância de cada um em sala de aula, e como o professor procederá e escolherá o tema a abordar. Mas, ao pensar sobre isto, que o professor analise cada escolha de interpretação de uma realidade e o necessário para a aprendizagem de seu aluno. 
O professor, muitas vezes, sem tempo e sem uma formação continuada de qualidade, faz dos conteúdos dos livros didáticos seu currículo, sua forma de reproduzir o conhecimento. Assim, a disciplina escolar é contemplada com outras formas dos conteúdos e conceitos a ensinar. A cada conteúdo maçante (a que ainda continua na escola, apesar dos avanços) é criticada e refletida por vários autores que buscam compreender as transformações da Geografia e a diversidade desta dentro da escola com o propósito de melhorar a formação e o conhecimento do professor, assim como dos alunos. Apesar da manipulação dos interesses da minoria, acreditamos que o professor faça diferença quando reflete sua capacidade de mudar essa situação dentro da sala de aula.

Assim, Castellar (1999), Cavalcanti (1998), Lacoste (1988), Moreira (1987), Resende (1986), Rocha (2001), entre outros teóricos buscam discutir a importância do ensino de Geografia na escola, e como o professor intervém de forma construtiva nos processos de ensino e aprendizagem de forma que articulem com a concepção curricular que faça com as ações do professor sejam efetivamente modificadas.

Segundo Rocha (2001) a importância da valorização do profissional em Geografia está ligada ao desenvolvimento de seu trabalho, para que ele possa agir politicamente na escola, pensando nos conteúdos que norteiam o ensino. O professor de Geografia tem de refletir sobre sua prática e sobre suas condições efetivas de trabalho. Ele repensará sobre qual Geografia ensinar e qual seu objetivo para discutir a função social da disciplina dentro do contexto escolar.

Então, nos perguntamos: como esse professor pode desenvolver um currículo e um ensino que promova um conhecimento crítico no aluno? A proposta é que ele desenvolva o seu trabalho e pense na estruturação dos conhecimentos geográficos de forma que seu modo de pensar, agir e analisar se direcione para a formulação de conceitos e conteúdos que dêem conta de debater nas aulas sua capacidade de intervir na realidade e de ter autonomia para discutir as várias questões intrínsecas no cotidiano.

Cavalcanti (2002) afirma que o professor de Geografia tem que se pautar na concepção de um profissional crítico-reflexivo, no qual a discussão deve estar pontuada sobre o seu papel na educação e em outras discussões para a construção da sociedade e para a definição do papel da Geografia na formação geral do cidadão. Desta forma, a autora argumenta: 
“... Considero necessário que seja garantido aos alunos o direito de conhecer as diferentes concepções sobre a ciência geográfica, de participar da reflexão sobre o papel pedagógico da Geografia, para que compreendam que a presença da Geografia na escola não é neutra, não é gratuita; ao contrário, ela deve estar presente na escola com propósitos políticos e pedagógicos bem definidos e conscientes". Cavalcanti (2002:113)

Pensamos que o ensino de Geografia deve trazer a compreensão política e social ao aluno de sua atuação no processo da construção da leitura espacial e identificar, analisar e reconhecer as diversidades dos fenômenos geográficos. O professor integra os aspectos pedagógicos os quais ajudarão no como transpor o discurso geográfico e sua finalidade como disciplina da escola a qual contribui para que o aluno apreenda a leitura dos fenômenos geográficos permitindo que o aluno se politize e analisa as estruturas e a organização espacial da luta entre classes em que vive.

Cavalcanti (2002) menciona que a construção da identidade profissional de Geografia faz com que se construa aquilo que o professor acredita como valores, o modo de ver o mundo, sua trajetória de vida, seu conhecimento, sua representação. $\mathrm{O}$ investimento em seu próprio conhecimento, e conseqüentemente, em sua prática, propõe ao professor, críticas e mudanças na Geografia que se ensina, trazendo novas perspectivas para se pensar no tipo de escola que queremos e na organização de um currículo que facilite o processo de ensino e aprendizagem do aluno.

A valorização da identidade profissional possibilita ao professor seu crescimento intelectual, fazendo-o analisar sua didática e seu processo de construção do ensino para que transponha ao aluno uma aprendizagem significativa.

O intuito de reunir os professores é que, por meio de leituras e reflexões acerca do seu trabalho, possam repensar suas ações em sala de aula, conforme citado abaixo:

\footnotetext{
"Acreditamos que os professores para serem autônomos, necessitam assumir posturas reflexivas e críticas sobre o ensino como prática social, e que podem fazer isso interrogando-se quanto aos resultados e à pertinência de seu trabalho, buscando referenciais teóricos que lhes possibilitem melhor compreendê-lo e aperfeiçoá-lo, produzindo, por meio de suas próprias investigações, transformações no seu pensamento e na sua prática docente". André (2002, 117:118).
}

Concordamos com os autores ao mencionar que os professores, para desenvolver sua autonomia devem pesquisar e refletir acerca da importância de seu trabalho dentro e 
fora da escola, tendo a responsabilidade de investir em sua capacitação profissional e na formação crítica de seu pensamento.

O intuito dessa pesquisa com os professores, foi o de conhecer um pouco sobre aqueles que transmitem ou constroem conhecimento junto aos alunos. Analisamos os questionários feitos por seis professores com experiência na área do magistério, tanto nas escolas particulares como nas públicas. Cada um tem uma experiência profissional e procura melhorar seu trabalho.

\subsubsection{Dados dos professores da Escola da Zona Leste:}

Os dados dos professores são relevantes para compreendê-los como agentes do processo de ensino e aprendizagem da construção do currículo. Tabelamos a resposta para melhor visualização e comparação das atividades dos professores.

\section{Professora 01}

A professora tem 34 anos, mora em Itaquera (Zona Leste), formou-se em Licenciatura Plena em Geografia na Universidade de Mogi das Cruzes em 1991 e em Administração de Empresa com ênfase em Comércio Exterior na Universidade de Tibiriçá. Está no magistério há 12 anos, e atualmente ministra 27 (vinte e sete) horas aulas semanais. Procura se capacitar participando de encontros oferecidos pelas editoras, oficina pedagógica - Leste 01, foi a um Congresso em Curitiba em 1994 e participou de cursos oferecidos pela USP nos anos de 1992 e 1993. Sua escolha pela Geografia se deu porque teve bons professores no Ensino Médio que fizeram despertar nela o interesse pela disciplina e, por gostar de viajar, percebeu o caminho para aliar teoria à prática.

Para ela, a Geografia no ensino fundamental tem como objetivo "alfabetizar" o aluno espacialmente, capacitando-o para ter noções de Paisagem, Espaço, Natureza, Estado e Sociedade. E isso está relacionado à importância dos professores em contribuir para que o aluno aprenda a organizar seu pensamento a partir do conhecimento informal, de forma a ampliar e transformar em conhecimento científico. Para isso, ela seleciona os conteúdos fazendo um levantamento de dados e de informações sobre o que os alunos sabem, o que se recordam das séries anteriores. Em seguida, conversa com os professores da área e de outras disciplinas para 
verificar o que poderia ser articulado durante as aulas; e no terceiro momento, faz uma pesquisa nos livros atualizados de autores conceituados de como trabalhar dentro da proposta do PCN.

Os caminhos utilizados pela professora são o estabelecimento dos objetivos da aula, os critérios de avaliação, os resultados finais e o aproveitamento global do aluno, bem como as competências que devem ser desenvolvidas. A metodologia para o funcionamento das aulas é fazer o aluno ter o prazer de conhecer, compreender e descobrir, cujos conceitos fundamentais são: Natureza, Globalização, Paisagem, Território, Região, Lugar, Estado e Sociedade.

Em relação à dificuldade encontrada em realizar qualquer atividade na escola são os desencontros nas reuniões entre ela e os professores para organizar o currículo de modo a favorecer a interdisciplinaridade. Estas dificuldades impossibilitam uma conversa entre seus pares para dialogar sobre os conteúdos a serem ministrados.

A importância da Geografia escolar é despertar no aluno o interesse para interagir de forma humanizada com a natureza. Procura proporcionar ao aluno entender sua importância no espaço em que vive. Para que ele compreenda essa dinâmica, é importante a escolha dos critérios para a seleção dos conteúdos os quais interagirão no espaço vivido pelo aluno. Essa escolha se dá pela sua utilização na vida prática, profissional, acadêmica que represente algo concreto, e o faça compreender as transformações do espaço.

Pensando desta forma, construir o currículo de Geografia é essencial, pois através desse há uma articulação entre as disciplinas, o que proporciona a interdisciplinaridade e o trabalho efetivo com as competências e habilidades. Construir o currículo compreende assumir no coletivo uma rede articulada de ações.

\section{Professora 02}

A professora tem 43 anos. Mora em Nossa Senhora do Carmo - Itaquera (Zona Leste) e formou-se em Licenciatura Plena em Geografia na Universidade São Marcos em 1999. Está no magistério há 14 anos. Atualmente leciona 27 (vinte e sete) aulas semanais. Procura se capacitar participando das Orientações Técnicas oferecidas pela Secretaria de Educação. Sua escolha pela Geografia se deu porque é uma matéria dinâmica e atualizada.

Para ela o papel da Geografia no ensino fundamental é proporcionar ao aluno o conhecimento do país em que vivemos e das diversas realidades sociais, econômicos e culturais que nele convivem. E isto está relacionado à importância dos professores em estimulá-lo, fazendo com que ele saia da rotina do dia-a-dia e aprenda com mais facilidade e entusiasmo. Para isso, seleciona os conteúdos com textos bem diversificados, de linguagem simples e de fácil entendimento, como revistas ou jornais. Ela pensa as aulas a partir sempre do "hoje", isto é, dos fenômenos geográficos que acontecem na atualidade e partindo também da 
experiência de vida que permita ao aluno ser um agente crítico do processo e um articulador de idéias.

Assim, os conceitos fundamentais quando se ensina Geografia são os que permitam ao aluno interpretar e analisar criticamente os conhecimentos adquiridos.

Em relação à dificuldade encontrada por ela em construir um trabalho multidisciplinar está no problema em que muitos professores não colaboram, ou seja, não querem trabalhar desta maneira. Um trabalho como esse possibilitaria dar significado aos conteúdos que permitiria ao aluno interagir dinamicamente com os temas propostos, partindo de sua realidade. Os conteúdos favorecem a construção do conhecimento do aluno desenvolvendo suas potencialidades, seu raciocínio lógico, sua criatividade e sua capacidade de aprender.

A importância da Geografia escolar é não perder de vista a realidade local do aluno para que ele assimile mais facilmente os conceitos propostos. Para que ele compreenda essa realidade, as aulas de Geografia devem oferecer subsídios ao desenvolvimento da cidadania, ao fazer com que o aluno compreenda o mundo em que vive, desde a escala local até a escala global. Construir o currículo de Geografia possibilita um aprendizado rápido, fácil e dinâmico.

\section{Professora 03}

A professora tem 45 anos, mora em Itaquera (Zona Leste), formou-se em Licenciatura Plena em Geografia 1984 e fez complementação Pedagógica na Universidade Camilo Castelo Branco. Está no magistério há 15 anos, atualmente com 40 (quarenta) aulas semanais. Trabalha em duas escolas distintas: uma estadual e uma particular. Procura se capacitar participando de encontros e congressos relacionados com a área de Geografia. Sua escolha por Geografia se deu por acreditar que seja uma disciplina que retrata os lugares e as diversidades culturais.

Para ela o papel da Geografia no ensino fundamental é fazer com que o aluno entenda a importância dele no espaço em que vive. Relaciona que a principal importância do professor neste processo é observar as mudanças e transformações que o espaço sofre constantemente. Sendo assim, escolhe os conteúdos de acordo com o cotidiano do aluno, mas trabalhando e observando revistas, jornais, internet, enciclopédias e etc.

Os caminhos, então, para se pensar as aulas é partir sempre de uma realidade, concreta e próxima, a considerar a faixa etária dos alunos e ter como "meio" livros, revistas, internet, passeios extra-classe. Para que o conhecimento geográfico ocorra, ela seleciona os conceitos como Lugar, espaço, organização e etc.

A dificuldade encontrada pela professora para produzir o conhecimento escolar é o excesso de alunos nas turmas e a falta de diálogo com outros colegas da disciplina. Menciona 
que os conteúdos fazem com que os alunos compreendam as mudanças constantes do espaço e o homem deve entender como agente transformador com esse espaço. Para isso, os conteúdos que favorece a construção do conhecimento do aluno são o do estudo do seu bairro, do seu município, por enfim, partindo para um conteúdo mais amplo (superfície terrestre).

A importância da Geografia escolar é que tudo faz parte de um todo, pois quando estamos estudando Geografia podemos partir para vários ângulos e isso é levar o aluno a compreender o espaço em que ele vive. Para isso, o currículo de Geografia tem que dar sentido a um determinado tema ("gerador") e levar o aluno a entendê-la e respeitá-la, por meio de notícias e acontecimentos do espaço vivido pelo próprio aluno.

\section{TABELA 1: INFORMAÇÕES GERAIS SOBRE OS PROFESSORES}

\begin{tabular}{|c|c|c|c|}
\hline Professores & Professor 1 & Professor 2 & Professor 3 \\
\hline Idade & 34 & 43 & 45 \\
\hline $\begin{array}{l}\text { Formação } \\
\text { Profissional/ } \\
\text { Acadêmica }\end{array}$ & $\begin{array}{l}\text { Licenciatura } \\
\text { Plena/Particular } \\
\text { Administração de } \\
\text { Empresa/Particular }\end{array}$ & $\begin{array}{l}\text { Licenciatura } \\
\text { Plena/Particular }\end{array}$ & $\begin{array}{l}\text { Licenciatura } \\
\text { Plena/Particular }\end{array}$ \\
\hline $\begin{array}{ll}\text { Tempo } & \text { de } \\
\text { experiência } & \end{array}$ & 12 & 14 & 15 \\
\hline $\begin{array}{l}\text { Horas } \\
\text { trabalhadas }\end{array}$ & $27 \mathrm{~h} /$ semanais & $27 \mathrm{~h} /$ semanais & $40 \mathrm{~h} /$ semanais \\
\hline $\begin{array}{l}\text { Encontros/Congr } \\
\text { essos/ Outros }\end{array}$ & $\begin{array}{l}\text { Encontros de editoras, } \\
\text { oficina pedagógica, } \\
\text { Congressos e cursos } \\
\text { pela USP }\end{array}$ & $\begin{array}{l}\text { Orientações Técnicas } \\
\text { da Secretaria de } \\
\text { Educação }\end{array}$ & $\begin{array}{l}\text { Encontros e Congressos } \\
\text { relacionados à área }\end{array}$ \\
\hline $\begin{array}{ll}\text { Escolha pela } \\
\text { Geografia }\end{array}$ & $\begin{array}{l}\text { Bons professores no } \\
\text { Ensino Médio que } \\
\text { fizeram despertar nela o } \\
\text { interesse pela disciplina }\end{array}$ & $\begin{array}{l}\text { Uma matéria dinâmica e } \\
\text { atualizada }\end{array}$ & $\begin{array}{l}\text { Por acreditar que seja } \\
\text { uma disciplina que } \\
\text { retrata os lugares e as } \\
\text { diversidades }\end{array}$ \\
\hline $\begin{array}{lr}\text { Função } & \text { da } \\
\text { Geografia Escolar }\end{array}$ & $\begin{array}{l}\text { Alfabetizar o aluno } \\
\text { espacialmente, } \\
\text { capacitando-o para ter } \\
\text { noções de Paisagens, } \\
\text { Espaço, Natureza, } \\
\text { Estado e Sociedade }\end{array}$ & $\begin{array}{l}\text { É proporcionar o } \\
\text { conhecimento do país } \\
\text { em que vivemos e das } \\
\text { diversas realidades } \\
\text { sociais, econômicos e } \\
\text { culturais que nele } \\
\text { convivem }\end{array}$ & $\begin{array}{l}\text { Fazer com que } 0 \text { aluno } \\
\text { entenda a } \\
\text { importância no } \\
\text { em que vive }\end{array}$ \\
\hline Critérios & Conteúdos fazendo um & Os conteúdos com & De acordo com \\
\hline
\end{tabular}




\begin{tabular}{|c|c|c|c|}
\hline \begin{tabular}{|l|} 
escolha \\
conteúdos
\end{tabular} & $\begin{array}{l}\text { levantamento de dados } \\
\text { e de informações sobre } \\
\text { o que os alunos sabem } \\
\text { ou se recordam }\end{array}$ & $\begin{array}{l}\text { textos diversificados de } \\
\text { linguagem simples e de } \\
\text { fácil entendimento }\end{array}$ & $\begin{array}{l}\text { cotidiano do aluno, mas } \\
\text { trabalhando } \\
\text { observando as revistas, } \\
\text { jornais, internet, e } \\
\text { outros }\end{array}$ \\
\hline $\begin{array}{l}\text { Caminhos para se } \\
\text { pensar as aulas }\end{array}$ & $\begin{array}{l}\text { Objetivos das aulas, os } \\
\text { critérios de avaliação, } \\
\text { os resultados finais e o } \\
\text { aproveitamento global } \\
\text { do aluno }\end{array}$ & \begin{tabular}{|lr} 
Sempre do "hoje", isto é, \\
dos & fenômenos \\
geográficos & que \\
acontecem & na \\
atualidade, & partindo \\
sempre da & experiência \\
do aluno &
\end{tabular} & 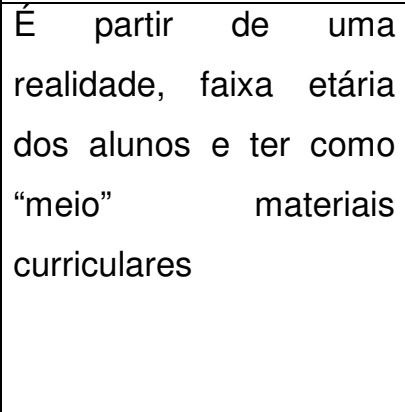 \\
\hline $\begin{array}{l}\text { Conceitos } \\
\text { fundamentais da } \\
\text { Geografia }\end{array}$ & $\begin{array}{l}\text { Conceitos } \\
\text { fundamentais: Natureza, } \\
\text { Globalização, } \\
\text { Paisagem, Território, } \\
\text { Região, Lugar, Estado e } \\
\text { Sociedade. }\end{array}$ & $\begin{array}{l}\text { São os que permitam ao } \\
\text { aluno interpretar e } \\
\text { analisar criticamente os } \\
\text { conhecimentos } \\
\text { adquiridos }\end{array}$ & $\begin{array}{l}\text { Lugar, Espaço, } \\
\text { Organização etc. }\end{array}$ \\
\hline \begin{tabular}{|ll} 
Dificuldades & de \\
trabalho & na \\
escola & \\
\end{tabular} & $\begin{array}{ll}\text { Desencontros } & \text { nas } \\
\text { reuniões entre ela e os } & \text { para } \\
\text { professores } & \text { parizar o currículo. }\end{array}$ & $\begin{array}{l}\text { Construir um trabalho } \\
\text { multidisciplinar. }\end{array}$ & $\begin{array}{l}\text { Excesso de alunos nas } \\
\text { turmas, desencontros } \\
\text { com os colegas }\end{array}$ \\
\hline \begin{tabular}{|lr} 
Tipo & de \\
conteúdos & que \\
favorece & $a$ \\
construção & do \\
conhecimento &
\end{tabular} & $\begin{array}{l}\text { Ė despertar no aluno o } \\
\text { interesse para interagir } \\
\text { de forma humanizada } \\
\text { com a natureza }\end{array}$ & $\begin{array}{l}\text { É a realidade local para } \\
\text { que ele assimile mais } \\
\text { facilmente os conceitos } \\
\text { propostos }\end{array}$ & $\begin{array}{l}\text { É que tudo faz parte de } \\
\text { um todo, pois quando } \\
\text { estamos estudando } \\
\text { Geografia podemos } \\
\text { partir para vários } \\
\text { ângulos. }\end{array}$ \\
\hline $\begin{array}{ll}\text { Significado } & \text { de } \\
\text { construir } & \text { um } \\
\text { currículo } & \\
\end{array}$ & $\begin{array}{l}\text { Construir o } \text { currículo } \\
\text { compreende assumir no } \\
\text { coletivo uma rede } \\
\text { articulada de ações. }\end{array}$ & $\begin{array}{l}\text { Possibilitar um } \\
\text { aprendizado rápido, fácil } \\
\text { e dinâmico. }\end{array}$ & $\begin{array}{l}\text { Dar sentido a um } \\
\text { determinado } \\
\text { gerador e levar o } \\
\begin{array}{llll}\text { tema } \\
\text { a entendê-lo e }\end{array} \\
\text { respeitá-lo. }\end{array}$ \\
\hline
\end{tabular}

FONTE: Pesquisa direta 


\subsubsection{Dados dos professores da Escola da Zona Sul:}

Conforme os dados dos professores, tabelamos as respostas para melhor visualização e comparação das atividades dos professores. As análises gerais ficaram em outro subitem.

\section{Professora 01}

A professora tem 35 anos, mora em Mirandópolis (Zona Sul), formou-se em Licenciatura Plena e Bacharelado em Ciências Sociais na Universidade de São Paulo em 1997 e Licenciatura Plena em Geografia pelas Faculdades Associadas do Ipiranga em 2001. Fez PósGraduação Lato-Senso em Ensino de Geografia pela PUC em 2004. Está no magistério há 10 anos, ministrando atualmente 45 (quarenta e cinco) aulas semanais (20 - vinte pelo Estado e 25 vinte e cinco pela Prefeitura). Procura capacitar-se participando de encontros, oficinas pedagógicas e cursos oferecidos pela USP. A sua escolha pela Geografia se deu por mão ter conseguido aulas de sociologia e, acabou gostando.

Para ela o papel da Geografia no ensino fundamental é propiciar a construção do conhecimento do aluno, no qual se refere a sua localização espacial, verificar as mudanças ocorridas no atual contexto mundial. Por isso, acha importante que o professor reflita sobre as atuais mudanças no perfil do aluno e na expectativa do mercado de trabalho. Procura, antes de escolher os conteúdos a serem ministrados nas turmas, conversar com os colegas (professores) da mesma disciplina, no início do ano letivo, e separar o material didático que possui em casa e nas escolas.

Depois disso, organiza as aulas traçando um plano de aula mensal para cada série, elaborando atividades e ouvindo (de vez em quando) os alunos, utilizando como conceitos fundamentais: Paisagem, Território, Lugar, Local e Espaço.

A dificuldade encontrada pela professora na escola é a falta de material didático e tempo para discutir com outros colegas. Se isso fosse viável os conteúdos se tornariam mais práticos para o aluno, pois todos trabalhariam coletivamente com conteúdos interligados à vivência do aluno. Exemplos: Município, Cidade (urbano).

A Geografia escolar é extremamente útil, porém não se deve descaracterizá-la como sendo apenas uma ciência de localização do espaço e sim, pensar a realidade atual. Para que a disciplina tenha sentido para o aluno, ela acha importante verificar se existe alguma proposta da escola, discutir com outros professores o planejamento dos conteúdos. É essencial que haja uma articulação entre as disciplinas, para proporcionar a interdisciplinaridade e fazer com que se 
possa trabalhar efetivamente com as competências e habilidades. Construir o currículo compreende assumir no coletivo numa rede articulada de ações.

\section{Professora 02}

A professora tem 38 anos, mora Na Vila Independência - Ipiranga (Zona Sul), formouse em Licenciatura Plena em Geografia na Fundação Santo André em 1985, e em Licenciatura Curta em História em 1991. Está no magistério há 16 anos, ministrando atualmente 51 (cinqüenta e uma) aulas semanais e trabalha em três escolas (particular, federal e estadual). Procura se capacitar participando, quando é possível, de encontros e Orientações Técnicas oferecidas pela Secretaria Estadual. Sua escolha pela Geografia por ser uma disciplina muito versátil e atual.

Para ela o papel da Geografia no ensino fundamental é auxiliar na compreensão do espaço, no processo de autoconstrução espacial e das inter-relações homem/ambiente, homem/homem. Por isso, a importância dos professores em mostrar ser possível a materialização do conceito, deixando-o menos abstrato. Isso perpassa também pelas escolhas dos conteúdos, que a princípio, são os indicados pelos PCNs, e que nesse segundo momento, são úteis para o "fazer cotidiano" do aluno. Em relação à parte pedagógica, para ela, cada comunidade tem sua necessidade. Não adianta querer forçar esta ou aquela - há casos em que numa mesma comunidade faz-se necessário várias práticas pedagógicas.

De acordo com ela os conceitos fundamentais para se ensinar Geografia vão depender da necessidade da turma, mas nem todos estão ao alcance dos alunos em todos os momentos. Nesse instante entra o papel do professor amadurecendo as idéias dos conceitos, coletivamente. Sendo assim, torna-os ao mostrar que a teoria existe porque pode ser colocada em prática e que estão presentes no seu cotidiano, ainda que de forma indireta (vegetação, clima, relevo, urbanização, produção, transporte, poluição...).

A importância da Geografia escolar é fazer refletir sobre como a teoria precisa ser retrabalhada e se tornar acessível aos alunos sem perder sua essência.

\section{Professor 03}

O professor tem 55 anos, mora no Sacomã (Zona Sul), formou-se em Licenciatura Plena em Geografia na Universidade São Marcos em 1995 e faz mestrado em Geografia Humana pela FFLCH-USP. Está no magistério há 12 anos, atualmente, ministrando 33 (trinta e três) aulas semanais. Para se capacitar está fazendo o mestrado, mas ultimamente não tem 
participado de congressos ou de qualquer outro evento. A sua escolha pela Geografia se deu por afinidade com a Natureza.

Para ele o papel da Geografia no ensino fundamental é o ensino e a prática da cidadania, homem/natureza. Acha importante a contribuição dos professores em trazer à tona as diferentes possibilidades de ação e prática do conhecimento. Escolhe assim, os conteúdos que tenha no cumprimento da exigência curricular e na associação ao cotidiano do aluno, procurando pensar as aulas que permita ao aluno olhar o mundo com simplicidade. Sua metodologia é a prática do cotidiano e a aplicação e desenvolvimento do conteúdo associado. Para ele, o conceito fundamental da Geografia é o conceito filosófico com um olhar geográfico.

Encontra dificuldades de produzir algo na escola devido a ausência de recursos e interesse, tanto do aluno quanto administrativo. A existência desses recursos, associados ao interesse do professor em trabalhar coletivamente, facilitaria o desenvolvimento dos conteúdos, o seu entendimento e a prática dos sentidos. Os conteúdos que facilitariam este processo de aprendizagem são os associados tanto ao homem/natureza, quanto à prática do conhecimento.

A importância da Geografia escolar é por meio da prática do conhecimento, ver que em tudo há Geografia. Sendo assim, na escolha dos conteúdos, procura, primeiro, aqueles ligados à exigência curricular, depois ao cotidiano do aluno, baseando-se então num critério técnicocientífico, construindo um currículo de Geografia que coloque à disposição dos interessados, as informações contidas na disciplina em questão.

TABELA 2: INFORMAÇÕES GERAIS SOBRE OS PROFESSORES

\begin{tabular}{|c|c|c|c|}
\hline Professores & Professor 1 & Professor 2 & Professor 3 \\
\hline Idade & 35 & 38 & 55 \\
\hline $\begin{array}{l}\text { Formação Profissional/ } \\
\text { Acadêmica }\end{array}$ & $\begin{array}{l}\text { Plena e Bacharel } \\
\text { Ciências } \\
\text { Sociais/Pública, em } \\
\text { Plena em } \\
\text { Geografia/Particular } \\
\text { Pós-Graduação em } \\
\text { Ensino de Geografia }\end{array}$ & $\begin{array}{l}\text { Plena em } \\
\text { Geografia/Pública, } \\
\text { Curta em } \\
\text { História/Particular }\end{array}$ & $\begin{array}{l}\text { Plena/Particular } \\
\text { Mestrado em } \\
\text { Geografia Humana/ } \\
\text { Pública }\end{array}$ \\
\hline Ten & 0 & 16 & 12 \\
\hline Horas trabalhadas & $45 \mathrm{~h} /$ semanais & $51 \mathrm{~h} /$ semanais & $33 \mathrm{~h} /$ semanais \\
\hline $\begin{array}{l}\text { Encontros/Congressos/ } \\
\text { Outros }\end{array}$ & $\begin{array}{l}\text { Encontros, oficinas } \\
\text { pedagógicas e cursos } \\
\text { pela USP }\end{array}$ & $\begin{array}{lr}\text { Orientações } \\
\text { Técnicas } \\
\text { Secretaria } \\
\text { Educação da } \\
\text { possível, Encontros }\end{array}$ & $\begin{array}{l}\text { Mestrado/Pública, } \\
\text { não tem participado } \\
\text { de nada }\end{array}$ \\
\hline Escolha pela Geografia & Não conseguiu aulas & disciplina & nidade \\
\hline
\end{tabular}




\begin{tabular}{|c|c|c|c|}
\hline & de sociologia & versátil e atual & Natureza \\
\hline $\begin{array}{l}\text { Função da Geografia } \\
\text { Escolar }\end{array}$ & $\begin{array}{l}\text { É propiciar a } \\
\text { construção } \\
\text { conhecimento do } \\
\text { aluno, no qual se } \\
\text { refere a sua } \\
\text { localização espacial, } \\
\text { verificar as mudanças } \\
\text { ocorridas no atual } \\
\text { contexto mundial. }\end{array}$ & $\begin{array}{l}\text { É auxiliar na } \\
\text { compreensão do } \\
\text { espaço, no processo } \\
\text { de autoconstrução } \\
\text { espacial e das inter- } \\
\text { relações } \\
\text { homem/ambiente, } \\
\text { homem/homem. }\end{array}$ & $\begin{array}{l}\text { É o ensino e a } \\
\text { prática da cidadania, } \\
\text { homem/natureza }\end{array}$ \\
\hline $\begin{array}{l}\text { Critérios de escolha } \\
\text { dos conteúdos }\end{array}$ & $\begin{array}{l}\text { Conversa com os } \\
\text { colegas da mesma } \\
\text { disciplina, separar o } \\
\text { material didático que } \\
\text { possui em casa e nas } \\
\text { escolas }\end{array}$ & $\begin{array}{l}\text { São os indicados } \\
\text { pelos } \\
\text { pCNs e fazem } \\
\text { parte do cotidiano }\end{array}$ & $\begin{array}{l}\text { Cumprimento da } \\
\text { exigência curricular e } \\
\text { na associação ao } \\
\text { cotidiano do aluno }\end{array}$ \\
\hline $\begin{array}{l}\text { Caminhos para se } \\
\text { pensar as aulas }\end{array}$ & $\begin{array}{l}\text { Plano de aula mensal } \\
\text { para cada série, } \\
\text { elaborando } \\
\text { atividades. }\end{array}$ & & $\begin{array}{lr}\text { Conceito } & \text { filosófico } \\
\text { com um olhar } \\
\text { geográfico }\end{array}$ \\
\hline $\begin{array}{l}\text { Conceitos } \\
\text { fundamentais da } \\
\text { Geografia }\end{array}$ & $\begin{array}{l}\text { Paisagem, Território, } \\
\text { Lugar, Local e } \\
\text { Espaço }\end{array}$ & $\begin{array}{ll}\text { Vão depender } & \text { da } \\
\text { necessidade } & d a \\
\text { turma } & \end{array}$ & $\begin{array}{l}\text { Tanto } \\
\text { homem/natureza, } \\
\text { quanto a prática do } \\
\text { conhecimento }\end{array}$ \\
\hline $\begin{array}{ll}\text { Dificuldades } & \text { de } \\
\text { trabalho na escola } & \end{array}$ & $\begin{array}{l}\text { Falta de material } \\
\text { didático, tempo para } \\
\text { discutir com os outros } \\
\text { colega. }\end{array}$ & & $\begin{array}{l}\text { Ausência r de } \\
\text { recursos e interesse } \\
\text { tanto do aluno } \\
\text { quanto administrativo }\end{array}$ \\
\hline $\begin{array}{l}\text { Tipo de conteúdos que } \\
\text { favorece a construção } \\
\text { do conhecimento }\end{array}$ & $\begin{array}{l}\dot{E} \text { uma ciência que } \\
\text { permite pensar o } \\
\text { espaço geográfico e } \\
\text { suas interfaces com o } \\
\text { cotidiano }\end{array}$ & $\begin{array}{l}\hat{E} \text { fazer refletir sobre } \\
\text { como a teoria precisa } \\
\text { ser retrabalhada e se } \\
\text { tornar acessível aos } \\
\text { alunos sem perder } \\
\text { sua essência }\end{array}$ & $\begin{array}{l}\text { Ver que em tudo há } \\
\text { Geografia }\end{array}$ \\
\hline $\begin{array}{l}\text { Significado de } \\
\text { construir um currículo }\end{array}$ & $\begin{array}{l}\text { Assumir no trabalho } \\
\text { coletivo uma rede } \\
\text { articulada de ações }\end{array}$ & & $\begin{array}{l}\text { Coloque à disposição } \\
\text { aos interessados, as } \\
\text { informações contidas } \\
\text { na disciplina em } \\
\text { questão. }\end{array}$ \\
\hline
\end{tabular}

FONTE: Pesquisa direta 


\subsubsection{Análise dados dos professores apresentados:}

A análise dos questionários é importante para levantar-se alguns dados relevantes na construção profissional desses professores. Conhecê-los, permite-nos entender um pouco o seu universo de trabalho bem como sua formação.

De um modo geral todos os professores fizeram Licenciatura Plena em Geografia. Tanto em faculdades particulares, dois na Universidade de São Paulo e em outras faculdades, como administração ou pedagogia. Os entrevistados têm mais de 10 (dez) anos no magistério e procuram capacitar em cursos oferecidos pela Secretaria de Educação. No entanto, chamou-nos a atenção o fato de a maioria só capacitar-se em OTs (Orientações Técnicas), isso quer dizer que os professores não vão a quase nenhum encontro oferecido por outras instituições como a AGB (Associação dos Geógrafos Brasileiros), a seminários e congressos ligados restritamente à Educação ou à Geografia. Apenas um deles faz mestrado em Geografia, mas a sua pesquisa está ligada ao planejamento urbano, e uma professora fez especialização em ensino de Geografia na PUC-SP. Assim, em relação à formação continuada dos docentes, são realizadas poucas vezes. O fato comentado por todos é a falta de tempo pelo excesso de trabalho, família e a falta de liberação da Secretaria de Educação para eventos de duração mais longa, uma vez que serão descontados.

Os professores têm carga semanal de trabalho entre 27 (vinte e sete) a 51 (cinqüienta e um) horas-aulas, o que reflete a falta de um bom salário, o que também prejudica a formação deles, uma vez que tendo uma carga alta de trabalho, propicia um dos problemas para o não direcionamento para realizar constantes capacitações.

A maioria respondeu que escolheu estudar Geografia por ser uma disciplina atual e ter relações com os lugares/espaços. Percebemos que os professores consideram a Geografia uma disciplina do cotidiano e que essa relação é interessante, porque pode se falar dos fenômenos que ocorrem de forma contextualizada.

Todos concordaram que a Geografia tem como objetivo no ensino fundamental levar o aluno a compreender seu espaço vivido. Os professores têm a preocupação em relacionar os fenômenos geográficos à realidade de seu aluno, o que justifica a argumentação que a disciplina trata de questões atuais e elegem como conceitos-chave para se entender os conteúdos de Geografia: Lugar, Paisagem, Região, Espaço e Território, que devem estar associados ao cotidiano escolar. A maioria escreveu 
também, que, ao selecionarem os conteúdos, procuram conhecer os alunos e buscam nos PCNs os objetivos necessários para o ensino e a aprendizagem da disciplina.

Percebemos que a maioria dos professores não desenvolve uma metodologia de ensino clara, o que dificulta, a nosso ver, as relações entre o ensino e a aprendizagem. Ao mesmo tempo, relatam que quando querem desenvolver alguma coisa para melhorar o processo de aprendizagem dentro da escola encontram diversas barreiras: a falta de incentivo de alguns professores, de material, de motivação dos alunos, de tempo, de conseguir conversar com seus pares e a própria direção que, muitas vezes, não permite o desenvolvimento dos trabalhos.

Pensam que Geografia escolar é importante para despertar no aluno o pensamento crítico, a compreensão do mundo que o cerca por meio da transformação do seu espaço. E para que isso aconteça é importante escolher os conteúdos que irão contemplar o processo de reconhecer, analisar e interpretar esse espaço em suas diferentes formas. Por isso, a reflexão sobre uma proposta curricular que articule o ensino de Geografia e o aluno, pois possibilita que este apreenda os conhecimentos escolares, além de facilitar o trabalho coletivo.

\subsection{Os alunos: os agentes do processo de aprendizagem}

Os alunos são os sujeitos ativos na escola, pois, é para a construção do conhecimento que o ambiente escolar deveria ser produzido. Este é o foco da aprendizagem no qual o trabalho de ensinar movimenta os docentes na busca de metodologias que os atinja e que orientem o seu processo de aprender, na medida que são parte dentro da sociedade e buscam no seu tempo escolar, conhecer novos amigos, integrar-se, relacionar-se e também educar-se para as descobertas do conhecimento e da vida.

O desenvolvimento sócio-educativo dos alunos está intrínseco na forma como vive e como se projete nesse mundo. Pensar nos alunos é entender suas funções dentro da escola que o fará agir em todos os ambientes: o de se socializar, o de estudar e o de aprender.

Segundo Jonnaert e Borght (1999), suas duas principais funções são (1) colocar seus próprios conhecimentos em interação com o saber e a partir dessas interações; (2) criar novos conhecimentos. $\mathrm{O}$ aluno é aquele em que o processo ensino-aprendizagem 
está sendo pensando e realizado. A escola procura trazer o aluno para o seu ambiente, fazendo-o parte interagente deste contexto.

$\mathrm{O}$ aluno tem de se relacionar com o ambiente novo, tem a tarefa de aprender um novo conteúdo, neste que é o meio pelo qual o aluno precisa alcançar e apreender os fenômenos geográficos que ocorrem em seu cotidiano. Depende do professor, e principalmente dele próprio, querer fazer parte da interação saber/professor.

Os deveres e os direitos que são parte do "ofício do aluno" Perrenoud (1995) estão atrelados às ações didáticas, ou seja, às ações que os orientarão no processo de aprendizagem e os que farão construir os conhecimentos geográficos. Os alunos devem ter o compromisso de estudar, de procurar desenvolver suas habilidades para uma melhor dimensão de interação com o professor e com o saber. É claro que ele tem escolhas, porque ele é o sujeito/objeto da ação da escola.

Entender os alunos é compreender as suas diversidades culturais. É olhar para eles e conhecer um pouco o seu modo de pensar e de agir dentro do espaço onde vive, criando condições para que associem seus saberes geográficos aos conteúdos escolares. Conforme Cavalcanti (2005) os alunos são sujeitos ativos do conhecimento geográfico, há uma representação social que cada um carrega consigo, o modo de perceber as paisagens, a rua onde moram, a cidade onde vivem. Nesta perspectiva, as condições sociais permitem aos alunos entender a organização espacial de sua cidade e pensar sobre ela.

A interligação entre o saber, o professor e o aluno deve ser nesta dimensão: fazer com que a prática do cotidiano do aluno seja orientada e vista sob o aspecto cultural e educacional para que este indivíduo veja sentido em estar no ambiente escolar. É nesta concepção da realidade vivida dos alunos que a Geografia deve ser construída.

A prática na sala de aula deve estimular o conhecimento geográfico do aluno, e fazê-lo analisar e entender o seu cotidiano, pode trazer relações com diversos tipos de conteúdos que para eles não passem de mais um "rol" de informações. Compreender o universo vivido é possibilitar aos alunos que eles desenvolvam uma leitura espacial sobre as mudanças dos espaços vivenciados trabalhando com os conteúdos nos quais vislumbrem fenômenos geográficos realmente significativos.

Mediante isto, buscamos conhecer um pouco sobre os sujeitos da aprendizagem e o conhecimento sobre a cidade onde vivem. 


\subsubsection{Os alunos da Escola da Zona Leste}

Observamos a turma EP 19/20 6 $6^{\text {a }}$ série na qual existem trinta e cinco alunos, sendo que vinte e um desejaram responder o questionário. A maioria está na faixa etária para a série, e que somente quatro estão acima dos treze anos. Praticamente todos nasceram no município de São Paulo e moram próximos à escola. Nas horas vagas fazem coisas diversificadas como: jogar bola, brincar e conversar com os amigos, ver televisão ou assistir DVD, estudar entre outros.

As ferramentas pedagógicas que utilizam no cotidiano em sua casa são ferramentas que auxiliam na aprendizagem indiretamente, ou seja, sem estar no ambiente escolar. Evidentemente que os mais usados são a televisão, o computador, o DVD/videocassete, TV a cabo, livros em geral.

Em relação à escola, a maioria gosta de frequientá-la e somente cinco alunos disseram que não gostam de ir à escola, pelo fato de que são obrigados. Dentre as respostas positivas estão: vão à escola para aprender, gostam dos professores e gostam dos amigos. Gostam da escola por causa dos professores, dos amigos e de usarem a sala de informática, entre as principais respostas; e não gostam da escola por causa: dos professores, das pessoas mal educadas, das aulas vagas, da merenda.

Em relação à disciplina Geografia a maioria escreveu que gosta por variados motivos: porque conhecem mais sobre o país, sobre o mundo e porque gostam da professora. Além disso, perguntamos o que eles gostariam de aprender na disciplina. As respostas mais relacionadas foram: conhecer sobre o mundo, sobre os planetas e não responderam nada.

Foi pedido para relacionarem coisas que eles percebem na sua rua, em seu bairro e no seu município. As respostas foram as seguintes: em sua rua - informações sobre serviços públicos (postes, asfaltos, prédios, escola), atividades comerciais (como mercearias, padarias) entre outras respostas; no seu bairro - informações sobre serviços públicos (hospitais, transportes, prédios, escolas, delegacia), atividades comerciais (supermercados, lojas), aparelhos de lazer e lugares religiosos, entre outros; no seu município - informações sobre serviços públicos (hospitais, transportes, prédios, escolas, delegacia, transporte), aparelhos de lazer e cultura (museus, parques e teatros), e outros não souberam responder. 
A partir disso perguntamos o que eles estudavam na Geografia que poderia ser associado ao cotidiano. As respostas gerais foram: conhecer melhor o mundo, tudo; alguns não souberam e outros não responderam.

\subsubsection{As percepções do cotidiano dos alunos da Escola da Zona Leste}

Nesta parte da pesquisa, junto com os professores, procuramos aguçar os alunos para descreverem o que eles conheciam sobre o seu bairro e município, em forma de redação, aquilo que achavam mais relevantes e fizessem parte do seu cotidiano. Observe os três exemplos a seguir. 


\section{14.

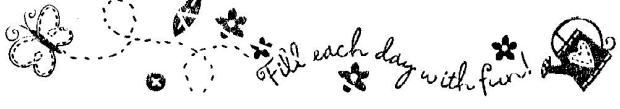 \\ silctets}

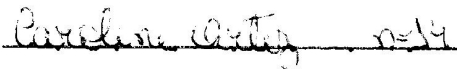

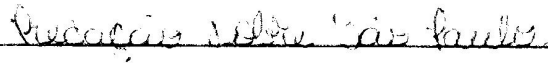

Jude en un déngar

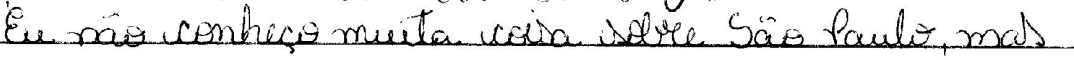

eu Jenho strguths de morar na maion motropali do sorail, di sir faulistona, ve tambim a teraiva maion metropoli de mundor.

Sä faulo temu wários lugares lindos, alguens leugares

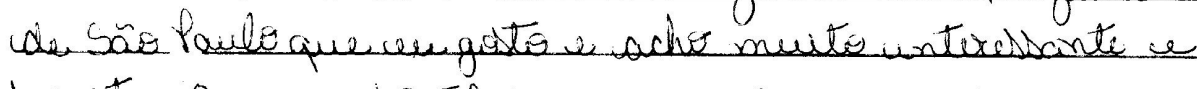
boniti: larque do I Burapuera, no carnoural ver aquele Sambédremo lutado nós diffiles, wer ele ló de cuma em.

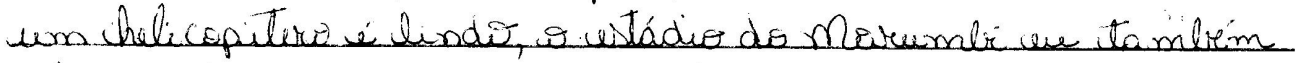
ache ile lindo, a luerida faulista toda mier mentada, wu sacho facinarente.

Mas nom tuds é eindir um Sấ fauls, a wroléncia Ĺ uma caia que tem en tods si lugar, e em Säe faulo nxio sé diferente, ne ano de leor acontecer io PCC (Primeiv Comando

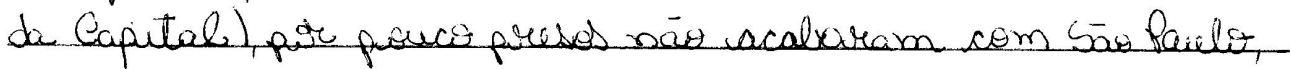
ninguím saia de cata para trabalhar, estudar todost tinlam medo de bair na Mica, a ínica coiva que urames cra tele-jernaies noticiande cada ônibus que tacaram fogit, cada pólicial que morren, cada pelsoa que morren liqui im staquera usse tambion acontexes.

Falondo sério, eu näo me lem lero de nenheim Lugar desnumbrante em itaquera, mas, eu gate de merear aqui, até perque a mi nha família está aqui Mas de un pudeste morar em voitro lugar de Sä́ faulo un goltaria de morou ns mostumbi, is Marumbi nâs foge da widéncia, mas uve acho aquela regiao muito bonita

\section{spirati:}


Gão Paulo

Em saí paulo a muitas corsas como: parques, slopping, pracicas e ete. Mas como Lodo lugar Tem suas diferencos, lambern a muitas mortes, érigas, lirotios e ete. Com tuds Isso sấ paulo e' sim, um lugar from para morar. Para mim viver em sais paulo i'muito form lirando a poluicáó - transito. En fa fui im outros lugares mas o melhor para morar, en acko que í em sai paulo.

No meu bairo + muito branque. lo a muito loom do vrver, porque lem muitas coisas pertó como Supermercado, padaria, farmacia, agongue e etc. Mas trambern. as vezes acontere, corsas esquisitas; brugas......

Viver em saé paulo é muito born !! ! ! ! 


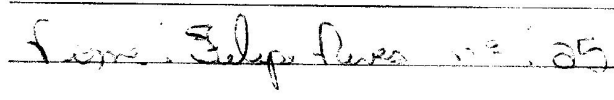

\section{Oque vejo e gato en Sä́ Pouls}

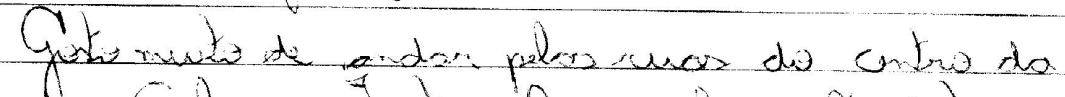

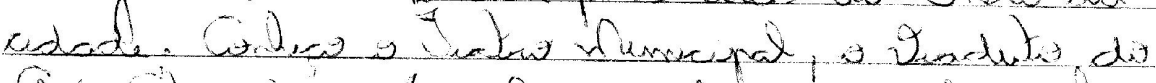
Qi, Cateonal do ti, rimp, alin de comer baumos

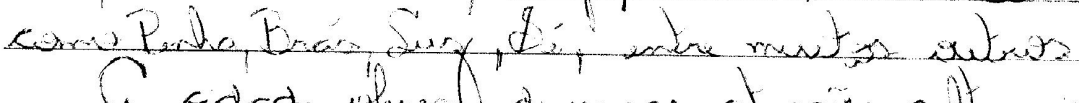

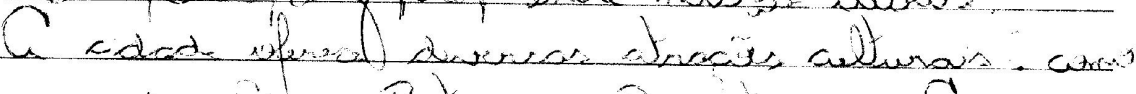

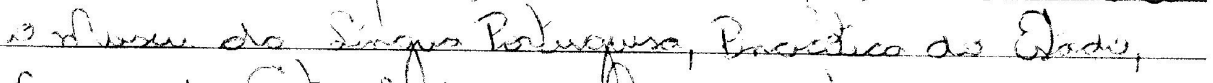

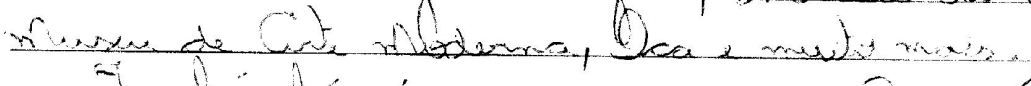

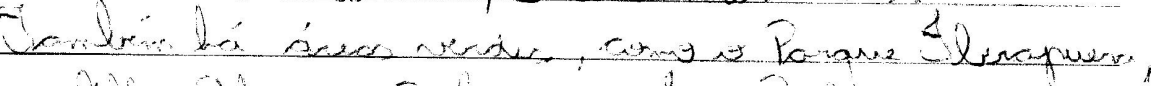

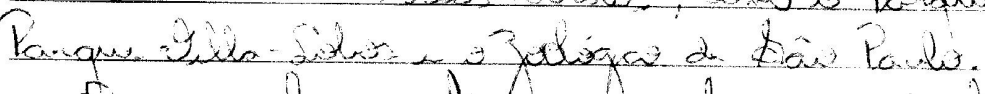

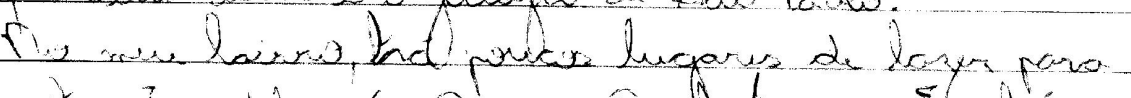

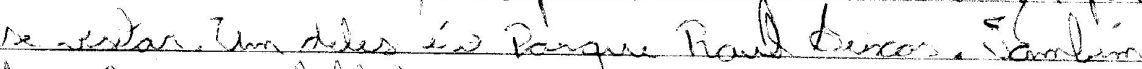
lá algumor blutiocos.

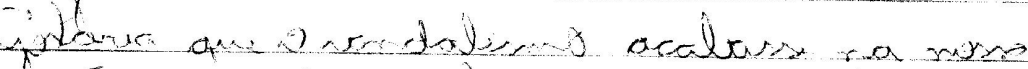

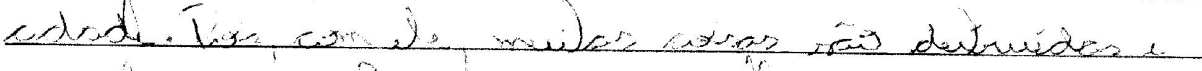

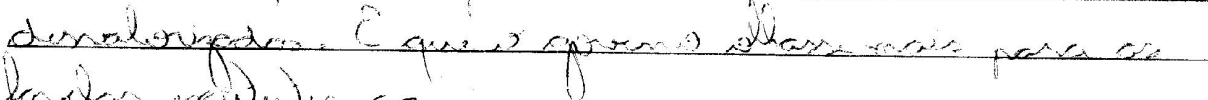

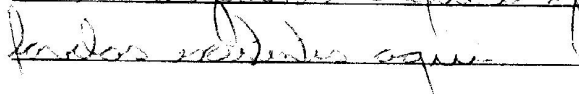

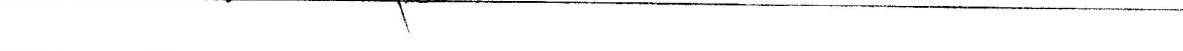




\subsubsection{Os alunos da Escola da Zona Sul}

Observamos a turma da $7^{\mathrm{a}}$ série na qual existem trinta e cinco alunos, sendo que dezessete alunos desejaram responder o questionário. Analisamos que todos da sala estão na faixa etária para a série. A maioria nasceu em outros municípios da região metropolitana de São Paulo e moram próximos à escola. Nas horas vagas fazem coisas diversificadas como: assistir TV, jogar bola, ler, ouvir música e conversar com os amigos.

As ferramentas pedagógicas que utilizam no cotidiano em sua casa são ferramentas que auxiliam na aprendizagem indiretamente, ou seja, sem estar no ambiente escolar. Evidentemente que os mais usados são livros, TV a cabo, o DVD/videocassete, entre outros.

Em relação à escola, praticamente todos gostam de freqüentá-la. Dentre a resposta positiva está: vão à escola para aprender e porque gostam dos amigos, gostam da escola por causa das matérias, gostam de estudar e dos amigos. Dentre as principais razões de não gostarem da escola é por causa dos professores, da bagunça, da merenda.

Em relação à disciplina Geografia todos gostam por variados motivos: porque eles conhecem mais sobre o mundo, para saber se localizarem, porque utilizam no cotidiano. Além disso, perguntamos o que eles gostariam de aprender na disciplina, e as respostas mais relacionadas foram: saber se localizar, conhecer sobre o mundo, conhecer mais o cotidiano.

Foi pedido para relacionarem coisas que eles percebem na rua, no bairro e no município onde moram. As respostas foram as seguintes: na rua - atividades comerciais (como mercearias, padarias), informações sobre serviços públicos (postes, asfaltos, prédios, escola), no bairro - informações sobre serviços públicos (hospitais, transportes, prédios, escolas, delegacia), atividades comerciais (supermercados, lojas), aparelhos de lazer e construções (prédios e casas); no município - aparelhos de lazer e cultura (museus, parques e teatros), informações sobre serviços públicos (hospitais, transportes, prédios, escolas, delegacia, transporte), atividades comerciais.

A partir disso perguntamos o que eles estudavam na Geografia que poderiam associar com o cotidiano. As respostas gerais foram: a questão da localização pela leitura dos mapas, discussão sobre o meio ambiente e os recursos naturais entre outras respostas. 


\subsubsection{As percepções do cotidiano dos alunos da Escola}

Nesta parte da pesquisa, junto com os professores, procuramos aguçar os alunos para descreverem o que eles conheciam sobre o seu bairro e município, em forma de redação, aquilo que achavam mais relevantes e fizesse parte do seu cotidiano. Observe os quatro exemplos a seguir.

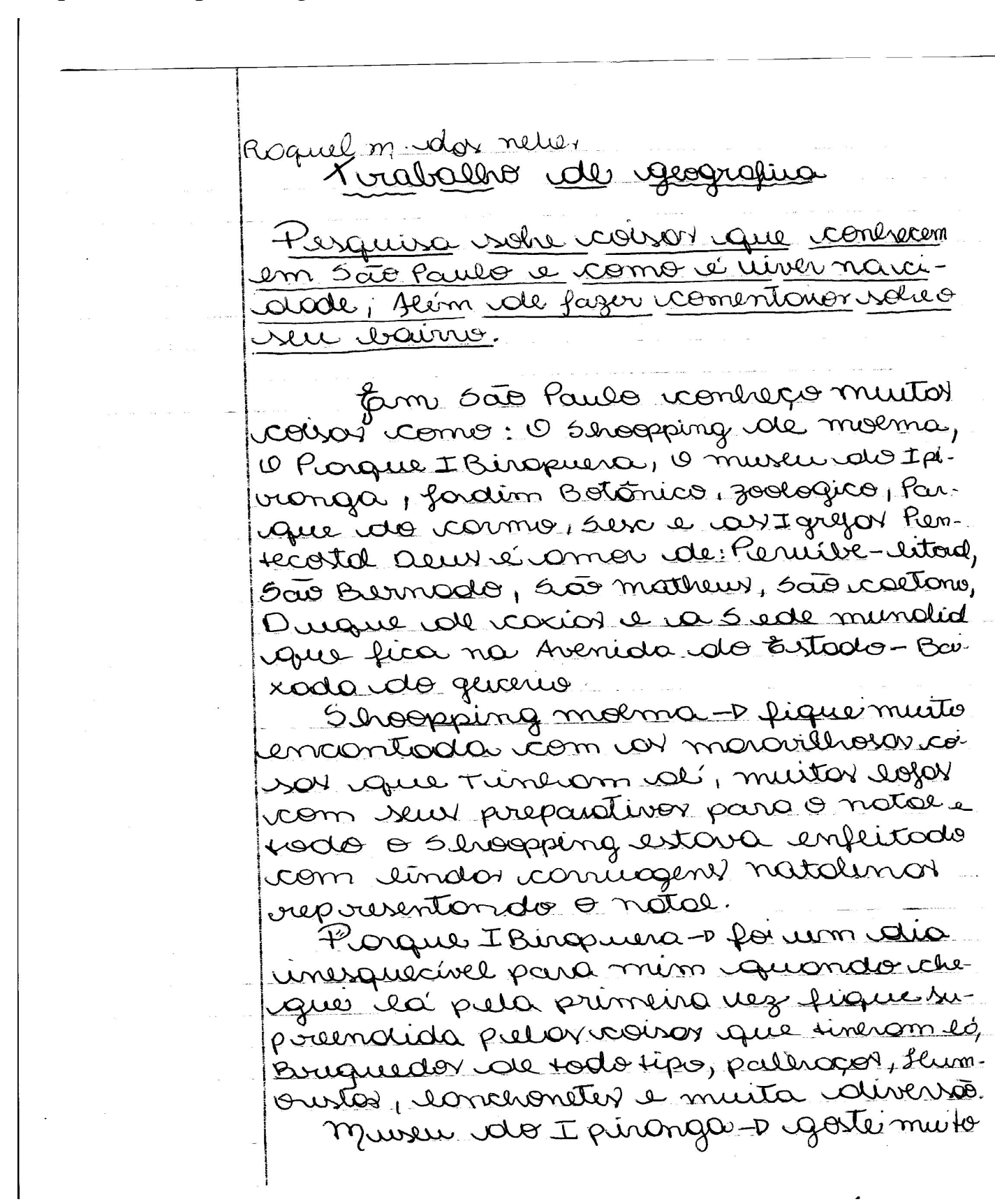


de ter vido la' pois hario muitos artgos ontigos para nos conerecermos e mutar diversos.

fondim Botönico $\rightarrow$ foium possio da escola que fomor funtomente. om todor os professaur e comigor ao chegarmos la' conlrecemos muitar coisa importonte sohe soneamento básico e Reviclogens de lutor todor saimor contentes e alugres doquelep. cossio.

zoologico $\rightarrow$ fu com a minho fomilia e odore em ver muitor. nimais que nem conbrecia. e fo muito legol.

Parque do cormo $\rightarrow$ fiv com or meur primor e nunca sinha vido num porque tó legol como aquele se divertimor $\theta$ dia inteiro quase a noite a goster muito.

5 exc-D fo um posseio tomberm da escola que fomor le a chegarmor lo' ngostomor muito.

i por véltimu as Igregar que conhece le ar que frequento que gosto muito de frequenta todor ular que folo onteriomente.

(1) Bairro em que moro que é. o Boino de fleluopolis, muitor pessoor lochom o ruim por Antigamente ser uma favela mar par mim l'um 
Baino muito born tern de tudo aqui supermercodos, padaior, P ostos de saí. de, aria da cultura para a comun. dode, telecentro-unas, Proça oo lodo do Horpital Heliopolis que e' mu to bom e que vem mutor pessoor de for para fozer trotomentor, temor tombem - Banco do povo que esta em plontóo para afudar a comenidade e mutar outrod coisos.

Para folo a verdade gasto m. uito do meu bárro a peson da minera casa nä sev verna monsō, mov l' uma cosa simples le humilde e temor muita alegria de wiver e conviver nesso cornenidode, tern os meur uzineror que sä otimos pessoos.

to eu me orgulho por morar na ciabole de sã Paulo, á pesor de ór vezer ser vema hida extressonte, consotivo, mar thedo isso pertence a uma lida contudiana de cado via em nossa cidode.

Av uezer nás temor tempo para soir para olgum ungas por cousa da correria do dio-dio mar vom. or vivendo a nossa lida cótudiona e ór vezes extressonter.

mutor pessoor que morom aqui tem vontade de ur em boro pcra $\theta$ nordeste, mav tudo isso é nound per que tombim precisomor do norsafa- 
milia.

ter moro aqui a mutor conor e tenlio minha fomilio no nodente e em tréz em três anor uou vizitolor na paraiba equando vou para la' fico um mês, mar logo jo sinte saudade de vim embora paro minlio cosinlwo aqui em saio paulo, gosto muito de mora aqui tem meur com. promussor e me esforce a codo dia para vamprir vom eles, as vezes l'vonsotivo e muite extressonte mol l' assim mesmo a vido ha cidode prencupalmente em Sä̃ Paulo. 


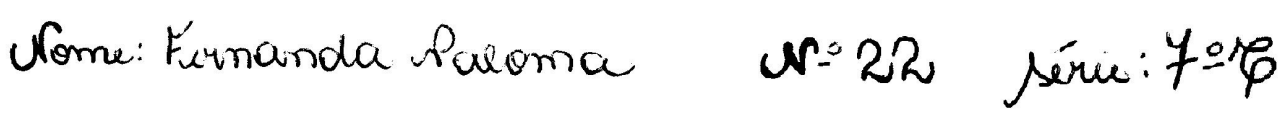

Eim Săd Paulo un contego váriax coisax e um desses lugarex é w que un maix gorto. Tu contugo soragas, centros culturais, hios, siti.

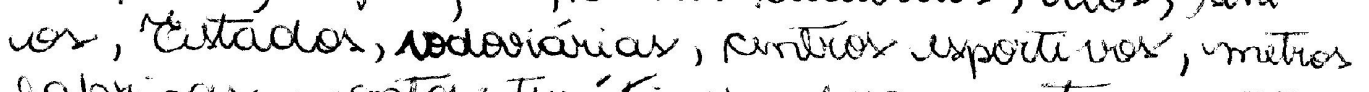
fiabricax, ypentos turisticas, lojas, vistaurantes, Shoppings, fintire da cidade, idificios, ypraiar upousadax, fórum, tribunal, dulegaciar, termi-

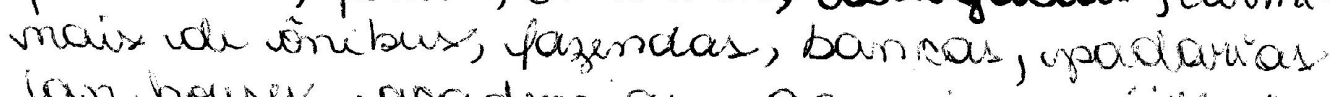
lan houser, academias, aguncias, liviratias, sava de móveir, ustádies, soura de Show, baladas, parques dé diverisgts, farmícias, univeridacules, curvos atc. untue usses sent

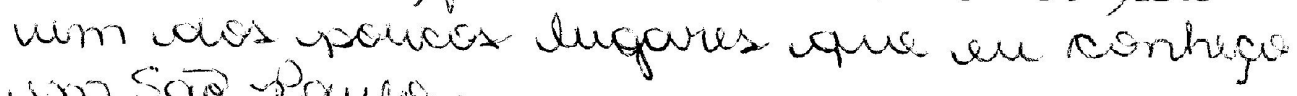
him sow - Paulo.

Tiver um la a paulo lé muito ruim porque tem imuitas pessoas poluindo co que nä é upla poluir, tim umilta violencia. poisa que he mols queria unem vra umim, inam pro próximo unas com violéncia on sum violuricia as upssoas trm que por a máo una corriémcia e fazer a coisa certa unáo la coisa vrada. 
Damila Dos Santos holg tac

fazer um relato sobk as coisas que corkecem em SAOO PAULO e como é viver na cidode, além de flazer comentários sobre sue BAIRRO

Bonkege vários lugares am SAO PAULO que sao muito morimentodos, por exemplo a estacigo proce da Sé, um lugor muits movimentado, por pessoos que trabalhom ou qui ustas à procura de emprexgs. Outro duga que en conhege é or Brás, Parque Dom Pedro, é um luga muito procurado para compiar roupas mais em conta I mas ra verdade naí compensa muito por que as roupas às vizes vem com defeito e você tern que ir lá trocer entáe o dinheiro que vocè paga nas possagens dá o mesmo valor se vori compor por aqui, - Parque dom Pedro é procurado mais para comprar tecidos, brinquedos, acussórios! etc. I lugar que en mais froquierto í Sas Eactano, rou muito ló pora is para - Parque thico iffendes, para o ifédvéo no ntercado, mo Shopping, vou passear por lá vários vezes ao decorrer do mếs.

Viver em Sa Pallo, muitas vezes é estressante, lé uma conéria, 5 ar Paulo. náo pola lé movimentado 24 shoras. Sàe Paule '́ uma cidade que há muita poluicas, o ar ré muito seco. Por um lado é bon arêl consegue as coisas um pouco nais

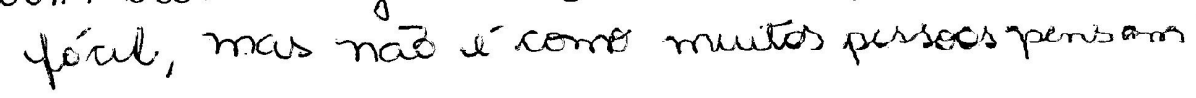


que aqui tido ímolezar, que ver pora cá, você corregue tudo mais fócil. "Por um lado é ruim por que tem muita peluicão, nä̃o tem muitas árveres cespolbdos na cidode, vocî najovê um berdé mmito difícil vocêven, se pelo menos tivesse maisverde agudoria a ter o or mais limpo. Nào gosto muito de viver ra cidade por que ì muito estressante, muitos vezes dá vontadede in para um lugar que tinha bostante verde, que tinha rio, que un possa andor tranquiblomente, se me preocupar, com a videncia.

Hue bairro $\mathrm{M}$ um bairro que tim mruitos pessods que sace cuentes, desimpregados, por causa de preconxeite, por que melamesno bairro theliópolis. Theu bairro í un bairo muto gronde, meu bairmo tim as ruas asfoltados, terr bastarte murcadinhos, videolocadoras, lonchonete, loja de blinquedos, term um infini Shopping lecalizado na florestal, tern Padorias, lojas de reupas, papscaias, meu bairre molarrs milhares de persoos, que labuta com vbrios situccás como lo jreconaito, na hora de arumas umpregg! na hora de ir no mercano e terr que dow

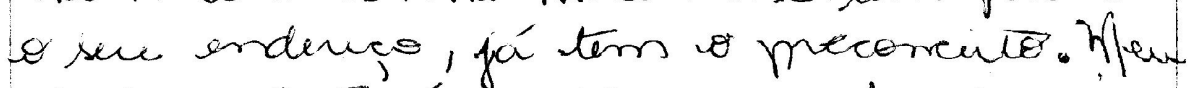
bairvo nas í mais unna fovela agora í um bairro, cono todos es outros. Mew bairro tem muitos projetos que ajudos as pessas que precison, leva a cen- 
dicao dos pessod fazerem um curso tololmente grátis, leva á tecnologia para que náo tern cendizä a pessoa rusder ito la mecher no computador quondo! quisen, lá terrs mais outros projetos reorno ajudoh as persods a arumar ó

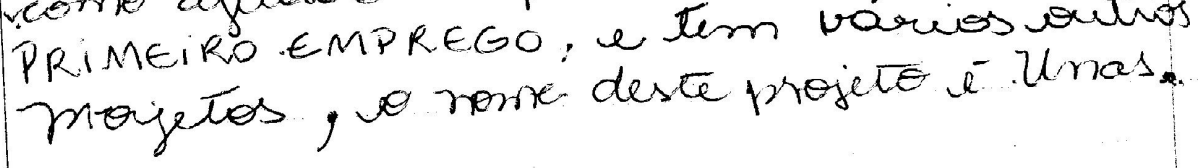


Nome Tayannes de ferw n: 34 isurie $7{ }^{\circ} \mathrm{C}$

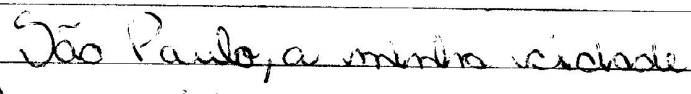

Să Paulo, a cialade do igarna e a cidade

-mais extens do Brasil. Lima cidode que guardo históreas, tristezos s alegrion.

Aqui thá várion yontos turísticon e coda urm

Iem a sua Shistória. Há vários parquespem mais lindo que a oitro, mas o mais conkecido l'o farmoso "Parque do I birapura." conde ho' lbastonte. verde, parquis, vmuseu, a oca e um matavilhass loge onde podemos vur o pồ-do-sol.

Falondo em museus, há Janabrím vários meseu,

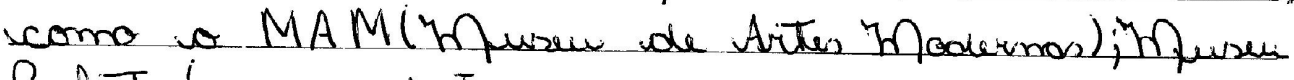
Paulista (museu do I pirrange, onde estam vguarabadas os objetar usador mo I impériol; thluseu da híngua Rortuguesa, o h hemorial da Américe hatima, a Pinaosteca da Estado ve untre rmitos outros. Também Tum umonumeños, Teatros, prédion e cases que falo urm pouco dessa vidade umaravilhosa. No centra há vários monumentos, ventre is. les intos: a Catedral da Sé, o Tuatro infunicipal,

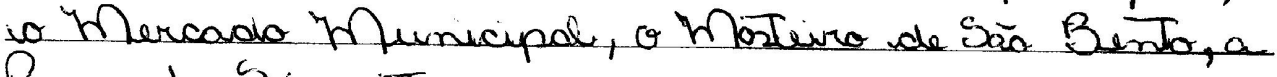
Praca da Sive oitros.

Ha Tandrim rion le as umain conbleciola vaqu is

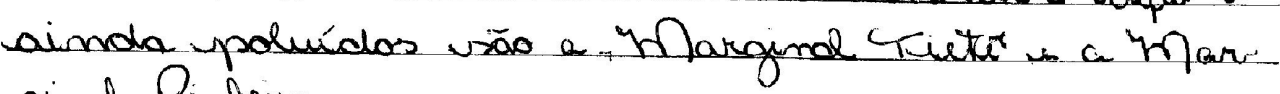
vainal Pinheuros.

Mlas Tombém uno poocia patar faltar ale falar Também de 2 avenidas bastante fopmora a-

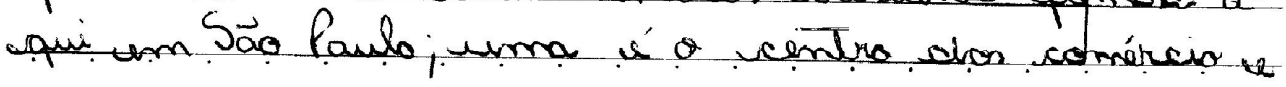




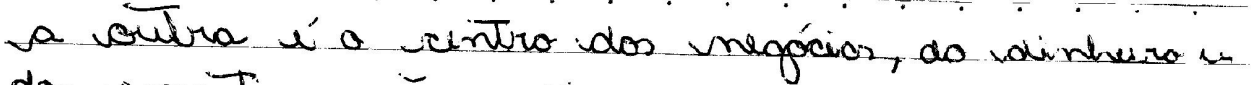
dos excecutiven, vöo ypodiamor de devirar de falor do Av. 25 de marco e Av. Paulinta que hoje s'as A avinidar mair comentados em 500 Paulo. Horar unuma cudode arsim tem vau la. do \& vo ruim Săo Paulo vi uma cidade bastante desenvol. vida. Thas para ivise destrvolvimento orvine muita ustudo, mos no futuro nom vei se cpode user imain, poir a volucacipo está upioromola a icada dia.

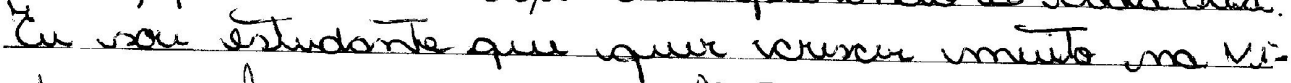
da e alcarager o men oljetivo, vei que poucos. una minho excla puno arim, ysoir wo vesto leva Tudo ma litimcadiva. (1) problema mim vao us uprofessores poin sei que lils uscolheram urso

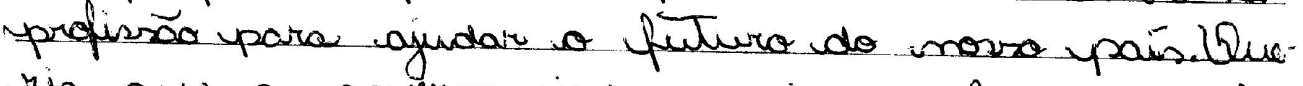
ria que o governo ajudarse, sei que hes ajudan bas. tante mas elus Jem que levar em vonta que o fuTure do nose cidade istá um urinco. Além da educação, a violéncia ú uma co.

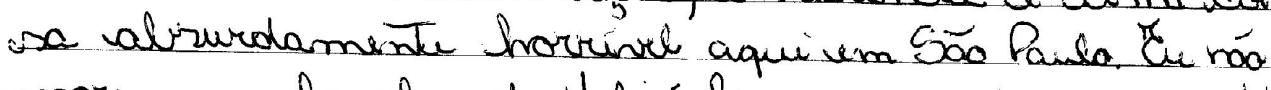
moro na farvela do Heliópolies, mas já umorei. Ho. je umeur pain tern uma cose proprina, vmos lem antes de uiten nosciab va viatencia ra favela da Heliópolis (a umaior de Sá Paubl ura Tervivel, mas ho-

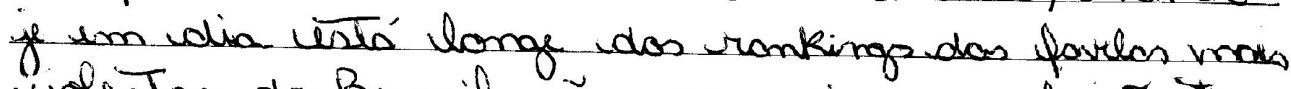
videntas do Biraxil, ñao porro dinger que la roo term vidéncire uman posso garanter que vmolhatou misto. A cada dis que passa a cidode itá mais videnta com os arvaltos, homicidio, assasentor, an 
cidente de trânrsto onde uminka máa já for urmo vétirma eqquase perdeu sua vida e leve haje os donos i es undrcas no corpo desse aconJecimento horrivel.

Ka minhe opinióa deveria melhorar a eder vacãor, a violencia le meio-ambiente do mossa cidod. 20 mic ambiente tombém li um foto muito sério une ronso cidade, uns do scosos is ifeito ustufa, e en culpados samos nós. Nusze proble. mon nós que termon que dor iniciativa, nö podemos colocat a culpa ne governo se nós Tombém wormon culpados 29 melhor aur io gover no pode fazer

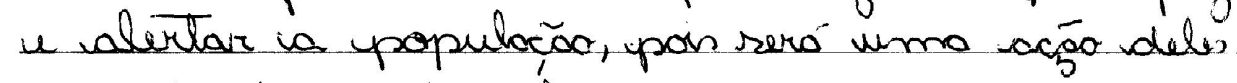
que depois será aplandeda Thlas um Säo Paulo ñö hó cousa ruims, tró Jilas coiras a ver prentigioda como os yarques, as uprac,as, as historiar, a uminice, as persoorse mititas orteran imimeras coinas.

The unore mo bairre Socomá. "t' um lavero tranquilo e bantante aconchiggnte Urme rodovia bastonte contrecids y a vodovic Anchuta que luga Sä Paulo va litiotal Paulista. In an Tambiom convidert ique moro no Ipiranga, onde foi dwoto o gito de D. PedroI pare Inolependéncia Tormlém a unne hirtória mão unvites conhecida, mos. Também faz parte do históris do paí, aqui Tem uma antinida chamoda Estrada das hagremon, ulá wo oomeco diva istrada uxirti uma aivvere que see chorma "árvore das hágrimos", pron que quando istove acontecendo a $2^{2}$ Querra mun- 


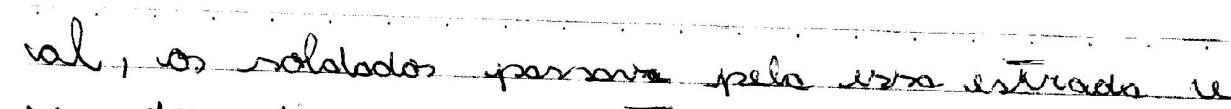
se despldic cos pranto com vera fomilia deibaxa verso árvore u iam a cominiat do Porto de Sañtos pars sols a querra.

mito Gorto muita do meu lairro quño sei minita aisa dele mos su que - o amo, alem old unenha cidode queresda. 


\subsubsection{Breve análise das percepções dos alunos}

Pedimos para que os alunos descrevessem o que conheciam sobre a Cidade de São Paulo e sobre o Bairro onde moram. O interessante foi que a princípio, não queriam fazer, alegaram que não conheciam nada. Contudo, quando um aluno comentou que já tinha ido a Rua 25 de março, todos começaram a falar.

Foi pedido, então, que tentassem escrever sobre o assunto. Percebemos várias coisas nas representações dos alunos sobre os lugares. Primeiramente, a questão da afetividade, uma parte relatou que "apesar da cidade ser violenta" ou "ser muito grande", gosta de morar nela e no seu bairro. Outro aspecto é a descrição da cidade como uma grande metrópole, entre as maiores do mundo, com espaços diferentes como o Parque do Ibirapuera (Ibirapuera - Zona Sul), os shoppings centers (espalhados por toda a cidade), Museu do Ipiranga (Ipiranga - Zona Sul), a Catedral da Sé (Centro da Cidade), Parque do Carmo (Zona Leste), Rua 25 de março (Centro da Cidade), Brás (Zona Leste) e outros que nos mostram o conhecimento dos alunos em relação às diferentes formas e funções da cidade como os locais de lazer, de serviços e de comércio, ou seja, sabem reconhecer os diferentes usos.

A questão dos problemas urbanos é relacionada pelos alunos ao descreverem sobre a violência, falta de asfalto, as favelas, o stress cotidiano, as poluições atmosférica, sonora e da água (a poluição do Rio Tietê) que são conteúdos geográficos com interface ao cotidiano dos alunos. Os alunos detalham esses fenômenos mostrando um domínio sobre aquilo que expressam. A violência (assaltos, homicídios) e as poluições são bem evidentes para eles, destacando-os como os principais problemas da cidade além da educação.

Há um outro lado da cidade e dos bairros que foram mencionados, como: tem belos parques e praças, suas histórias, a música, as pessoas, as atividades culturais, as compras na Rua 25 de março, no Brás ou em Itaquera (centro comerciais com produtos baratos). Essas são formas de enxergar a cidade com "aspectos bons", com lugares significativos para eles, onde se divertem e "esquecem" os problemas urbanos da cidade.

Temas esses que podem ser trabalhados nas aulas de Geografia ao se tratar a questão urbana, industrial, os impactos do ambiente, o território, o lugar, o espaço, as transformações e permanências das paisagens e outros. 
Os alunos, em seus relatos, nos mostram que, apesar de uma visão romântica da cidade e do seu bairro, fazem uma relação com os diferentes tipos de lugares e de atividades existentes em São Paulo e em seu bairro. Eles percebem, de certa forma, a organização espacial, a partir do momento em que eles relatam, o que existe em seus bairros, porque é significativo se morar lá; mas, ao mesmo tempo, o caos que é morar numa das maiores metrópoles do mundo.

A perspectiva é mostrar que o aluno tem conhecimento do espaço em que vive, e que o professor deve trabalhar para estruturar cientificamente os conceitos e os conteúdos geográficos que permitirão ao aluno pensar e analisar a cidade e o bairro em que vivem de forma crítica. 


\title{
CAPÍTULO II
}

\section{A CONSTRUÇÃO DOS ELEMENTOS CURRICULARES DE GEOGRAFIA: A PRODUÇÃO ATUAL EM DUAS ESCOLAS ESTADUAIS NO MUNICÍPIO DE SÃO PAULO E AS INTERVENÇÕES HISTÓRICAS}

\author{
"Desde um enfoque processual ou prático, \\ o currículo é um objeto que se constrói no processo \\ de configuração, implantação, concretização e \\ expressão de determinadas práticas pedagógicas e \\ em sua própria avaliação, como resultado das diversas \\ intervenções que neles a operam. Seu valor para os alunos \\ que aprendem seus conteúdos, depende desses processos \\ de transformação aos quais se vê submetido".
}

Sacristán (2000:101) 


\subsection{O movimento do currículo para compreensão de sua produção}

O nome "currículo" deriva do latim "scurrere" que significa corrida, caminho, jornada, trajetória, percurso a seguir. No currículo é preciso traçar planos, ter metas, saber os objetivos e saber fazê-los para que no fim sua "jornada" ou sua "trajetória" seja completa e satisfatória, ou seja, fazer o currículo é, saber qual a sua intenção, de que forma construí-lo e para que fim. É um diálogo entre a escola e os agentes envolvidos no processo.

Os currículos têm por objetivo orientar a construção do conhecimento escolar. É por meio deles que são regidas a teoria e a prática de todo o processo no ambiente e a dinâmica do tipo de ensino que a escola oferece. Não são simplesmente desenhos curriculares, mas são as transformações de todo um contexto: para que se ensina, do que se ensina e qual a intenção política e social que se irá contemplar. A forma como se produz o currículo está relacionado ao tipo de aluno que está se formando, qual o objetivo da formação docente e do ideal de escola.

O currículo surge, efetivamente, a partir do momento em que a escola se organiza para ser uma instituição formal de ensino no fim do século XVIII, com o objetivo explícito de "sistematizar o conhecimento transmitido à população". Desde então, o estudo do currículo e o interesse pela sua organização são ferramentas importantes para o Estado e para o sistema econômico em formar futuros profissionais para o mercado de trabalho, porque se direciona os objetivos e os conteúdos necessários para a compreensão da realidade e a orientação de técnicas, normas e formas que permitam o ingresso ao mercado de trabalho, para o vestibular e para a vida social. Cada contexto histórico caracteriza formas políticas e econômicas nas quais diferem a escolha dos conceitos e conteúdos e a dinâmica escolar.

As teorias curriculares marcam períodos, que se vinculam a um contexto histórico e a concepções ideológicas impostas. Silva (1999) relata estas relações das teorias em que o currículo se torna mais que um simples documento "é lugar, espaço, território, relação de poder, é documento de identidade”. Ou corrobora Apple (2001:8):

"O currículo nunca é apenas um conjunto neutro de conhecimentos, que de algum modo aparece nos textos e nas salas de aula de uma nação. Ele é sempre parte de uma tradição seletiva, resultado da seleção de alguém da visão de algum grupo acerca do que seja conhecimento legítimo. É 
produto das tensões, conflitos e concessões culturais, políticas e econômicas que organizam e desorganizam um povo".

$\mathrm{O}$ autor argumenta que a escolha dos elementos que serão escritos no currículo não é neutra, pois o ato de selecionar é relacionado a uma concepção ideológica, política, social e cultural das pessoas envolvidas no processo. Cada contexto histórico, concepção filosófica e conceitual direciona o conhecimento, a estrutura da organização escolar e das disciplinas que organizavam o processo educativo.

Atualmente, as concepções que vigoram estão atreladas à relação da sociedade capitalista, sua relação de produção, de circulação, de vida, da luta entre classes (mesmo que "camuflada"), bem como as relações de gênero, de cultura, entre outros. Uma certa mistura entre as concepções modernas e pós-modernas.

Essa relação é percebida na comparação entre os currículos, por exemplo, da década de 70 e o da década de 90, a conjuntura econômica, política, cultural e social eram totalmente diferentes; conseqüentemente, as formulações curriculares organizamse de acordo com os contextos de cada época.

Com os currículos podemos estabelecer relações no processo do trabalho dos conteúdos na sala de aula, mas também questões políticas, ideológicas, culturais..., porque o currículo envolve relações de poder.

Da teoria tradicional à pós-crítica, observamos que os currículos se tornam grandes instrumentos ideológicos, produzindo profundos pré-conceitos, isolando conhecimento ou simplesmente ignorando-o. Isto fica bem claro, quando Lucíola L.C. Santos (2000) comenta sobre Young (1978:220): “Currículo é uma construção e uma invenção social, o que torna necessário analisar os valores e interesses sociais que levam a inclusão e a exclusão de determinados conhecimentos nos processos de escolarização".

A história da teoria curricular mostra como os teóricos concebem o currículo, dividindo-o em três tipos: tradicional, crítica e pós-crítica. Cada história curricular também mostra tendências educacionais, pedagógicas que influenciam na construção da escola e na prática pedagógica.

$\mathrm{Na}$ teoria tradicional, o currículo foi estruturado nos moldes do sistema econômico do início do século XX. A principal base foi o sistema organizacional de Frederich Taylor, que estabelece os princípios administrativos dentro das empresas. A escola, então, preocupa-se em organizar sistematicamente o currículo. 
Um dos primeiros a discutir sobre currículo foi Bobbitt em seu livro The Curriculum de 1918, no qual transformou o currículo numa organização científica. Sua proposta baseava-se na teoria organizacional taylorista voltada para a economia, quando a educação deveria ser "eficiente", isto é, trabalhar e desempenhar um papel semelhante às das empresas, bem como das industrias. Para John Dewey, com linhas mais progressistas preocupadas com questões democráticas, o currículo era produzido de acordo com os interesses e as experiências de crianças e jovens. Para ele, a educação não deveria preparar para uma vida ocupacional adulta, mas para compreender a vida.

Até então, estabeleciam-se duas formas de ver o currículo: os técnicos voltados para a economia, e os progressistas com base psicológica.

Já na teoria crítica, o currículo foi modificado em consequiência da formação conceitual nos quais alguns autores como Freire (1970), Young (1971), Apple (1979), discutiram a ideologia do currículo, como se presta a estruturar o sistema capitalista, ou seja, a cultura dominante e se fazer como a linguagem dominante. Criaram-se então, outras linhas, como a Reconceptualista, que se torna contra a visão técnica do currículo e inclui as questões sociais para repensá-lo.

Para Apple (1979), o currículo deve ser ativamente produzido, isto é, voltado para o campo ideológico, de forma a possibilitar aos alunos terem valores e atitudes. Para Giroux (1987) o currículo deve ser orientado para a questão da política cultural, ou seja, a cultura influenciando nas concepções curriculares.

As teorias pós-críticas trabalharão a valorização da diferença, identidade (multicultural), relação das mulheres, parte étnica e racial (saber e poder), o pósmodernismo e outros, ou seja, conceitos que foram aflorando nas relações sociais, principalmente nas décadas de 80 e 90 e que buscam a igualdade de gênero e a contribuição da minoria. ${ }^{4}$

Hoje, acreditamos que o significado do currículo seja em orientar como a escola deve se organizar para dar fins a sua função, ou seja, estabelecer determinados parâmetros para se pensar e estruturar as orientações político-pedagógicos, administrativos e sociais com o propósito de legitimar o papel da escola enquanto um espaço sócio-cultural-educativo.

\footnotetext{
${ }^{4}$ Aqui estamos apenas fazendo uma pequena referência. Para aprofundamento é interessante fazer a leitura de SILVA, Tomaz Tadeu da. Documentos de identidade: uma introdução às teorias do currículo. Belo Horizonte: Autêntica, 1999, no qual ele faz uma revisão sobre o assunto.
} 
Estamos chamando a atenção para o fato de que em cada época o currículo se modifica de acordo com o poder vigente, com a forma de pensamento e com o tipo de estrutura escolar que a sociedade e o governo programam. Não é somente um discurso, mas é um poderoso artefato social que organiza a forma estrutural do ambiente escolar e, principalmente, o tipo de saber que se deseja transmitir. Para isso, entender o que significa uma disciplina e o seu conteúdo é de suma importância. Como comenta Sacristán:

\begin{abstract}
"As teorias desempenham várias funções: são modelos que selecionam temas e perspectivas que influem nos formatos que adota o currículo de cara a ser consumido e interpretado pelos professores tendo assim um valor formativo profissional para eles; destinam o sentido de profissionalidade do professorado ao ressaltar certas funções, oferecem uma cobertura de racionalidade às práticas escolares. As teorias curriculares se convertem em mediadoras ou em expressões de mediação entre o pensamento e a ação na educação". Sacristán (2000: 43-44).
\end{abstract}

Sabemos que a construção do conhecimento escolar se realiza na metodologia, na didática do professor, mas que ele segue determinações gerais do plano nacional no caso brasileiro dos PCNs, ou dos Estados e dos Municípios.

A utilização de conceitos centrais é de fundamental importância para estabelecer uma relação mais direta com o objeto e objetivo da disciplina e da prática escolar. $\mathrm{O}$ currículo, então, deve abarcar os problemas, práticas e concepções também de cada localidade. Assim Sacristán (2000: 32). diz: “O currículo está implicado todos os temas que tenham alguma importância para compreender o funcionamento da realidade e da prática escolar em nível de aula, de centros, o de sistema educativo".

Desenvolver o currículo de acordo com a realidade local implica numa prática específica dos professores, numa formulação curricular efetiva, e assim, proporcionar uma discussão no grupo docente. Isto favorece tanto o currículo prescrito quanto o currículo real Goodson (1995), pois o professor constrói sua teoria com a prática cotidiana dentro e fora da sala de aula.

É importante frisar que esta discussão não é recente. Desde a Pedagogia Histórico-Crítica há uma preocupação em valorizar o espaço da criança, da sua vivência, do seu modo de enxergar o mundo. Mas, quando se remete ao cotidiano escolar, observamos que os conteúdos e a própria organização escolar estão direcionadas para um trabalho mais conteudista e que na grande maioria das vezes, não 
articula o conhecimento vivido do aluno. Libâneo destaca a dimensão crítico-social dos conteúdos:

“...implica vincular os conteúdos de ensino a exigências teóricas e práticas de formação dos alunos, em função das atividades da vida prática. A assimilação ou apropriação de conhecimentos e habilidades adquire importância e sentido se proporciona o domínio ativo e prático de modos de atuação crítica e criativa na vida, na profissão, no exercício da cidadania. Por essa razão, somente se dá a assimilação crítica dos conteúdos quando se faz a ligação destes com as experiências reais e concretas vividas pelos alunos na sua prática social” Libâneo (1994:137-138)

Ou seja, a preocupação em articular as experiências concretas dos alunos aos conteúdos já está na história das tendências pedagógicas do Brasil, mas essa referencial é muito pouco visto e trabalhado na escola. Se há essa discussão dentro do processo teórico do currículo e da pedagogia, pressupomos, então que há algum problema na relação ensino e aprendizado.

A história do currículo nos remete a essas questões, apesar do avanço filosófico, a escola não "alcançou' ou ainda não "assimilou” essas novas possibilidades. Além disso, as próprias necessidades também mantêm o regime de uma pedagogia tradicional, os conteúdos estanques, fragmentados, proporcionando à formação dos discentes essa fragmentação e apenas um conhecimento científico, sem a contextualização.

Neste sentido, Arroyo (1999) diz que a tarefa pedagógica não consiste em simplesmente criar um novo currículo, “mas pensar nas práticas cotidianas dos próprios professores e alunos, nas virtualidades inovadoras que há no ato educativo". Ele argumenta que o professor é o sujeito e inovador, e o ato de produzir é uma maneira de incentivá-lo a perceber que o conhecimento não pode ficar fechado somente aos "teóricos", porque seu trabalho está interligado a uma realidade diferenciada, principalmente na escola, um universo repleto de cultura.

\subsection{A produção de elementos curriculares: o caso de duas escolas estaduais de São Paulo}

O conhecimento na escola é uma tarefa muito importante no trabalho docente, pois a produção de qualquer saber é o elo para que o aluno se projete na sociedade e conviva nela de forma crítica e construtiva. 
Esse conhecimento se perpassa dentre tantas coisas, na própria condição do professor, em repensar sua disciplina e os conteúdos ministrados, os quais possibilitarão a tríade aluno, professor e saber. Em vista disto, procuramos por meio das metodologias da pesquisa-ação trabalhar conjuntamente com os docentes para que reflitam sua prática cotidiana, agindo com eles e dinamizando no debate a importância de trabalhar a Geografia de uma forma viva.

Antes das observações acerca dos elementos curriculares propostos pelos professores, queremos destacar alguns pontos relevantes para chegarmos ao objeto da pesquisa. Procuramos no ano de 2006, em conjunto com as discussões, realizar uma observação não-participante nas salas dos docentes, porque analisamos como conduziam as aulas, os conteúdos, às inter-relações dos alunos.

Em relação à escolha dos conteúdos, os professores "reproduziam' os planejamentos dos anos anteriores ou "seqüências do livro didático", uma vez que as três primeiras reuniões anuais por todos os professores se limitavam a discussões pedagógicas gerais e como seria o funcionamento da escola. Restava apenas o último dia para a "discussão" dos planejamentos, não sobrando tempo para uma reflexão mais efetiva sobre o que ensinar e a importância do que ensinar para os alunos.

Percebemos a pouca organização nos encontros pedagógicos relacionados a uma organização curricular e sobre o processo de desenvolvimento e construção dos objetivos do ensino e aprendizagem da disciplina para a escola. $\mathrm{O}$ currículo abarca várias concepções importantes que estão relacionadas à formação docente, os materiais e espaço escolares, grade curricular, os alunos, a comunidade externa, os fatores políticos, sociais, econômicos, culturais e ideológicos dos componentes da escola, o processo de ensino e aprendizagem.

Durante o processo de pesquisa, procuramos trabalhar com os professores com o intuito de que refletissem sobre alguns elementos curriculares que fossem importantes para a concretização do trabalho na sala de aula, interagindo a teoria à prática, ou seja, na formulação desses elementos que pensassem em suas concepções da Geografia para que traçassem metodológica e didaticamente uma intervenção na aprendizagem na qual o aluno compreendesse a importância dos fenômenos geográficos no seu cotidiano.

Cremos que a metodologia da pesquisa-ação possibilitou aos professores nas reuniões, com as leituras de texto e os debates entre eles, a orientação para uma escrita conjunta e a valorização do porquê ensinar a disciplina Geografia a fim de que seja um reflexo, na prática do desenvolvimento dentro da sala de aula de uma aprendizagem 
mais significativa para os alunos. A possibilidade de repensar o que ensinar, deve ser fruto de uma intervenção na escolha do tipo de currículo feito na escola e, sobretudo como a teoria e a prática se entrecruzam.

Elementos esses apontados por Coll (1996), Sacristán (2000) que não podem estar somente centrados na questão política, ideológica e teórica, mas que de fato haja a preocupação prática desses elementos na construção do desenvolvimento do ensino e da aprendizagem do aluno. Obviamente, Apple (2001) argumenta que todo currículo é, uma "seleção do ponto de vista das pessoas que estão produzidos, política, cultura e social da época vigente", assim como Moreira, A. e Silva (2001) Silva (1999) nos mostram que a cada momento histórico o currículo nos orienta nas relações tanto político-culturais como sócio-educativas e que por meio dessas conjunturas nos permita repensar a produção curricular tendo em vista os aspectos educativos do momento.

Pensar o currículo como "práxis" é torná-lo em ação, em movimento entre a teoria e a prática dentro da concepção e da própria Geografia.

Destarte, a concepção atual da teoria curricular é pós-crítica que trabalha com a valorização das diferenças, multiculturalismo, e outros elementos pertinentes a uma nova concepção também de sociedade capitalista que vislumbra formas de produção, a valorização da mulher e sua inserção no mercado de trabalho, estudo das raças, étnicas e do multicuturalismo existente, a reorganização da vida urbana e social da sociedade, as relações de poder, as concepções de lazer e de trabalho, a questão do consumo e da mercadoria; todos esses aspectos e vários outros que envolve o repensar a dinâmica atual, questão pertinente ao desenvolvimento de paradigmas curriculares por entre o tempo.

Repensar isto é analisar o mundo em que vivemos e pensar os objetivos fundamentais de se estudar Geografia dentro da escola, de forma a intervir numa melhoria de interpretação, descrição e análise na construção de um aluno que desenvolva sua capacidade de interpretar geograficamente a realidade cotidiana de forma crítica e analítica e se entenda como um ser espacial e como essa influência afeta o seu modo de se socializar com a sociedade.

Mediante as ações dos professores, sua concepção de Geografia, da prática pedagógica, produziram um texto com elementos curriculares que, para eles foi importante para pensar a disciplina, a escola e a concepção de conhecimento. 


\subsubsection{Alguns elementos da Proposta Curricular organizada pelos professores de Geografia da Escola da Zona Leste:}

\section{Introdução}

O currículo deve estar centrado no sujeito (aluno) ${ }^{5}$, criando um conjunto flexível de oportunidades de aprendizagem que permite o desenvolvimento de competências para a formação social do aluno.

Deve-se considerar o ensino como processo de construção de conhecimentos, e o aluno como sujeito ativo deste processo e, em conseqüência, a ênfase em atividades de ensino que permitam a construção do conhecimento como resultado da interação do aluno com os objetos do conhecimento.

O currículo de Geografia deve contribuir para que o aluno aprenda a organizar seu pensamento a partir do seu cotidiano, para depois introduzir o conhecimento científico. Sabemos que para despertar o interesse do estudante pela Geografia, é necessário aproximar, o máximo possível os conteúdos da disciplina em seus aspectos conceituais, procedimentais (como fazer, como proceder?) e atitudinais (solidariedade, cooperação, cidadania e ética), da sua realidade cotidiana.

Compreender o universo vivido dos alunos para problematizar, discutir e relacionar seus conhecimentos prévios fazendo relação entre a escala local e o mundial, é uma ação fundamental na prática de ensino-aprendizagem. Para os adolescentes as práticas de problematização e discussão têm como meta a expansão do raciocínio, mantendo sempre a ligação com a realidade social existente.

Kaercher (apud Cavalcanti 1999:112) demonstra uma preocupação quanto à inclusão da Geografia do cotidiano em sala de aula. Segundo ele: "Geografia não é só o que está no livro ou o que o professor fala. Você a faz diariamente. Ao vir para a escola a pé, de carro ou de ônibus... o homem faz a Geografia..."

Para organizar a proposta curricular de Geografia os PCN e PCN+ sugerem alguns temas estruturadores como parâmetros de aprendizagem:

1. Natureza
2. Globalização, técnicas e redes
3. Paisagem
4. Território, região e lugar
5. Escala
6. Espaço geográfico

\footnotetext{
${ }^{5} \mathrm{O}$ trabalho pedagógico deve estar organizado em torno da aprendizagem. O professor propõe problemas (pesquisa), cria oportunidades de aprendizagem e desenvolvimento das competências.
} 
Segundo Coll (1999), para elaborar um projeto curricular é preciso abordar quatro pontos essenciais:

- Que ensinar? - procura selecionar os elementos que permite o crescimento pessoal de cada aluno e guiar e planejar a ação pedagógica e a organização das seqüências temporais.

- Quando ensinar? - possibilita a organização das seqüências do ensino e aprendizagem dentro do processo curricular

- Como ensinar? - devemos sempre relacionar a teoria e a prática, buscando o ensino produtivo e não reprodutivo para desenvolver as competências e habilidades, procurando organizar ações individuais e grupal, estimulando a criatividade.

- Como e quando avaliar? - deve ocorrer a cada início de uma aprendizagem, durante o processo e no final da aprendizagem, mas deve-se avaliar todo o desenvolvimento do aluno (interpretação, comportamento e a própria aprendizagem).

Um dos pontos centrais do currículo é o proceder de uma análise, classificação e identificação de possíveis intenções (inventário), quais aspectos são relevantes tratar para promover um aprendizado. Devemos organizar e ordenar temporalmente os conteúdos de maneira coerente e concisa para promover as etapas importantes no processo de aprendizagem. Outro ponto a ser discutido é a metodologia de ensino.

De acordo com Coll (1999), a avaliação é um processo de ensinoaprendizagem que deve fazer parte de um projeto curricular, uma vez que busca mostrar os progressos, as dificuldades que marcam o processo. Por meio da contextualização e de atividades interdisciplinares são propostas atividades que adequam o conhecimento geográfico a uma linguagem própria do aluno, criando situações de aprendizagem na qual o conteúdo se torna significativo, favorecendo o desenvolvimento de habilidades e competências.

As três grandes competências propostas para a área de Ciências Humanas e Tecnológicas $(\mathrm{CHT})^{6}$ são:

- Representação e Comunicação - buscam desenvolver a capacidade de comunicar informações partindo de questões problemas;

- Investigação e compreensão - visa organizar informações contidas em diferentes linguagens;

\footnotetext{
${ }^{6}$ Adaptado dos PCN+
} 
- Contextualização sócio-cultural - visa possibilitar que o aluno identifique e compreenda que as ações humanas são construídas em tempos e espaços físicos e sociais diversos.

Devemos dentro da Proposta Curricular inserir atividades alternativas que possibilitem melhor aprendizado dos alunos não como receituário, listagem de conteúdos, mas como elemento norteador da organização curricular e da definição de competências e habilidades básicas a serem desenvolvidas.

\section{Objetivos da Geografia na escola}

Conforme os PCNs o principal objetivo de qualquer disciplina é atender as necessidades dos alunos para formá-los cidadãos e integrá-los no mundo do trabalho. Para isso, os jovens devem ter acesso ao conjunto de conhecimentos necessários ao exercício da cidadania.

O ensino de Geografia pode desempenhar um papel importante na configuração da identidade, para a reflexão sobre a atuação do indivíduo (aluno) nas suas relações pessoais ao grupo no coletivo e suas atividades de compromisso com classes, grupos sociais, culturas, valores e gerações do passado e do futuro.

Permitir o estudo da Geografia do aluno, pois ele é sujeito da aprendizagem, frente ao meio externo, o qual deve ser "inserido" no processo como objeto de conhecimento e deve ter como meio (que são conteúdos escolares) uma relação ativa, um incômodo/desafio que o leve ao desejo de conhecer e estudar as transformações do espaço em que vive.

O papel da geografia é "alfabetizar" o aluno espacialmente capacitando-o para adquirir noções de Paisagem, Espaço, Natureza, Estado e Sociedade. A leitura e a interpretação da linguagem cartográfica são importantes para o aluno compreender as espacializações dos objetos. Ensina-lo a distinguir os diferentes espaços e, cartografálos, é uma maneira de alfabetizá-lo.

A Geografia, segundo os PCNs, é uma ciência que contribui para pensar 0 espaço enquanto uma totalidade na qual se passam todas as relações cotidianas e se estabelecem as redes sociais. Então, se presta a observar o lugar em que se vive e avaliar criticamente a qualidade/variedade cotidiana ao longo dos ciclos; perceber os problemas sociais e ambientais como temas coletivos e passíveis de solução para o exercício da cidadania; procurar identificar as organizações existentes (igrejas, ONGs, 
etc.) no bairro para colaborar na luta pela defesa dos direitos/deveres como fundamentais para construção de uma sociedade democrática; desenvolver uma postura ativa e comprometida com a busca de soluções.

\section{A importância das Competências e Habilidades:}

As competências e habilidades no mundo atual da educação são temas muito discutidos, porque, por meio deles, podemos melhorar a qualidade do ensino e de aprendizagem do nosso educando. Estabelecê-las nos permite agir de forma a garantir que os conteúdos tenham um significado e se que possa atingir um objetivo final. No caso da Geografia, é permitir que o aluno saiba se localizar, analisar e criticar o espaço em que vive.

Para tanto enumeramos algumas competências e habilidades relevantes para esse processo:

- Identificar linguagens cartográficas, isto é, fazer com que o aluno desenvolva a capacidade de interpretar as diferentes formas de mapear e analisar o espaço;

- Ler, interpretar e questionar as relações entre cidade-campo;

- Analisar as diferentes técnicas e costumes e a diversidade de paisagens entre o campo e a cidade;

- Identificar linguagens cartográficas que representam as relações campocidade.

- Comparar, interpretar fotos, mapas e tabelas;

- Identificar as semelhanças e diferenças entre as regiões;

- Compreender e relacionar elementos naturais, sociais, econômicos e políticos;

- Pesquisar em dicionários, jornais, revistas, internet com objetivo de sistematizar o conhecimento do cotidiano;

- Compreender a importância da história para a compreensão dos fatos do presente;

- Identificar e analisar o a apropriação da natureza na construção do território;

- Relacionar - sociedade e natureza - base para compreender o espaço geográfico; 
- Valorizar as atitudes de solidariedade e comprometimento com políticas que visem acabar com a pobreza e diminuir as diferenças.

\section{Objetivos dos Conceitos:}

Os conceitos são os meios pelos quais os professores estruturam a aprendizagem de determinados objetos de forma que possam desenvolver nos alunos a compreensão das diferentes concepções das diferentes disciplinas com o propósito de promover uma aprendizagem que possibilite ao aluno entender o mundo em que vive e agir sobre ele.

A Geografia tem um papel importante dentro do processo educativo, por meio deles, os alunos aprenderão a se organizar e a criticar a produção do espaço criado pela sociedade em que vive.

Achamos os conceitos mais relevantes dentro da Geografia:

- Lugar, paisagem e espaço geográfico - objetiva-se que os educandos compreendam que o lugar em que vivem e as paisagens que podem observar fazem parte do espaço geográfico, ou seja, do espaço terrestre transformado pelo trabalho humano, entendendo como o estudo da Geografia, contribui para a compreensão do mundo em que vivemos e como nos dá subsídios para torná-lo cada vez melhor. O espaço geográfico define como o conjunto indissociável de sistemas de objetos (rede técnicas, prédios, ruas) e de sistemas de ações (organização do trabalho, produção, circulação, consumo de mercadorias, relações familiar e cotidiano), que procura revelar as práticas sociais dos diferentes grupos que nele produzem, lutam, sonham, vivem e fazem a vida caminhar (Santos, 1999).

- Orientação e localização - desenvolver noções de orientação e localização no espaço terrestre, além de conhecer e distinguir as diferentes formas de representar a superfície e os lugares da Terra.

- Território - conhecimento do país em que vivemos e das diversas realidades sociais, econômicas e culturais que nele convivem, oferecendoIhes oportunidade de refletir criticamente sobre uma realidade e gerar atitudes de respeito pelos vários segmentos culturais que o país abriga.

- População - identifique os aspectos de crescimento, da estrutura e da distribuição da população brasileira, a fim de se conscientizarem da 
importância desses aspectos no planejamento político-administrativo e no desenvolvimento social do país.

- Região - reconhecer as divisões do território nacional em estados, municípios e distritos; compreender as formas de regionalização do espaço mundial. Levar o aluno a compreender a relação existente entre as características naturais e o desenvolvimento das atividades econômicas, e observar os contrastes existentes dentro da própria região.

\section{Objetivos dos conteúdos:}

O objetivo é levar o aluno a reconhecer-se numa visão de mundo cujos pressupostos busquem fundamentar-se de modo reflexivo, crítico. Contextualizar os conhecimentos geográficos, tanto no plano de sua origem específica quanto em outros planos: histórico e cultural; sociais, científico e tecnológico. Os conhecimentos que o aluno vai adquirir que envolvem o saber historicamente acumulado.

O ensino e aprendizagem devem se fazer de maneira seqüencial para uma maior assimilação por parte dos alunos. Os textos selecionados devem ter clareza, a fim de possibilitarem uma aprendizagem mais fácil, mais dinâmica, mais eficaz. É necessário também conhecer a clientela, saber com quem estamos trabalhando e sempre partir do local para o global.

Reconhecer suas capacidades, potencialidades e dificuldades; abrir-se para as diferenças e habilitar-se a aprender com argumentos morais e éticos.

Visar a um comportamento que indique valores, atitudes, crenças. Ex. O trabalho em equipe, a comunicação, a capacidade crítica, a convivência e a solidariedade, a criatividade.

Auxiliar o aluno a desenvolver competências de mediação entre ele mesmo e os diferentes conhecimentos, tornando-o mais criativo.

\section{O desenvolvimento dos conteúdos por séries:}

Para a 5a série - Geografia Diária, partindo sempre do cotidiano do aluno e valorizando o conhecimento prévio, tendo como procedimentos básicos da disciplina: observação, descrição, comparação e representação, introduzindo conceitos fundamentais: Paisagem, Espaço, Lugar e Território. 


\section{As transformações do espaço geográfico nos dias atuais: a cidade e o campo}

Onde nos localizamos nessa transformação:

- As relações dos pontos cardeais e colaterais;

- As coordenadas geográficas;

- Os diferentes mapas e suas implicações;

- Do local ao mundial: fazendo relações do seu espaço vivido e os diferentes espaços.

As transformações no espaço geográfico urbano e rural:

- As mudanças e permanências nas diferentes paisagens representadas e seus diferentes significados;

- Surgimento das cidades;

- As diversas atividades urbanas e agrícolas: indústria, agricultura, transporte, recursos naturais e minerais e o turismo;

- As pessoas que vivem nesse espaço e sua diferença cultural;

- As mudanças no meio físico: a transformação da crosta terrestre, a litosfera e a degradação ambiental, a hidrosfera e sua poluição acelerada, a atmosfera e as mudanças antrópicas e os ecossistemas.

Objetivos específicos:

- Reconhecer como a geografia contribui para compreensão do espaço vivido e sua relação com o espaço mundial;

- Dominar as suas posições mediante o local ao mundial, ou seja, ter conhecimento da sua localização no bairro, no município, no estado, no país e no mundo, mas também em relação ao seu próximo;

- Conhecer, identificar, analisar e interpretar a linguagem cartográfica, ou seja, que possibilite o aluno compreender como os mapas auxiliam no processo de conhecimento de determinado lugar e de seu espaço vivido;

- Compreender as mudanças e permanências impressas na paisagem dos espaços rural e urbano e o seu surgimento; 
- Compreender os processos conceitos relacionados ao campo e a cidade: conceitos de cidade, município, centros urbanos, funções urbanas, campo e etc.

- Identificar as diferentes formas de atividade do campo e da cidade: a formação das atividades industriais, das atividades agrícolas, o uso dos recursos naturais e minerais, o transporte e a inserção do turismo como negócio;

- Analisar como o homem se utiliza o meio físico para gerar produtos;

- Interpretar a termologia solo (aspectos físicos e aspectos das cidades) como forma de apropriação do território);

- Analisar como as diferentes pessoas se organizam nesses espaços e como o próprio espaço se insere nesse contexto: as migrações e as diferenças culturas;

- Compreender o caráter dinâmico da crosta terrestre e analisar os diferentes processos (sua camada, tectonismo, vulcanismo, movimento sísmicos, a formação geológica e geomorfológica), tendo a atuação antrópica nessa transformação;

- Compreender a maneira que a litosfera é formada e transformada (as principais formas de relevo no qual o aluno habita, os agentes que modelam essa paisagem), sendo degradada e interferindo na cotidianidade das pessoas;

- Compreender a dinâmica da hidrosfera, sua importância para o surgimento das cidades, para a sociedade e como a poluição afeta o seu uso (industrial, agrícola, residencial e comercial);

- Compreender a dinâmica da atmosfera e como o processo antrópico cria mudanças locais.

- Analisar como a interferência antrópica acelerou o processo de degradação ambiental e a tentativa de resgate por meio de estudos que possibilitem uma melhor qualidade de vida a população.

Obs: Todos os objetivos citados acima deverão ter análise e representação da linguagem cartográfica.

Disciplinas integradas: História, Língua Portuguesa, Arte, Matemática e Geografia.

Na 6⿳a série fazer uma retomada dos conceitos do ano anterior, enfatizando o Espaço Geográfico do Brasil. 


\section{Os diferentes contrastes sociais, culturais e econômicos desse espaço chamado}

\section{Brasil.}

Que lugar é esse?

- Conhecendo o lugar Brasil;

- As transformações do nosso território: do natural ao meio técnico científico informacional e seus diferentes mapas;

- Processo de regionalização do território brasileiro.

Conhecendo as transformações do espaço brasileiro: as relações e mudanças do espaço rural e urbano e suas implicações no meio físico:

- IBGE e as diversas formas de regionalização;

- As diferenças regionais (aspectos sociais, políticos e econômicos) e o processo de mudanças nos espaços rural, urbano e industrial;

- As diferentes culturais do espaço brasileiro: os diferentes povos que construíram a nossa paisagem e a migração;

- As diversas formas de relações de trabalho entre o rural e o urbano;

- Conhecendo o meio físico que modelam o Brasil e são apropriados por ele apropriados - os elementos do relevo, solo, clima, hidrografia e vegetação;

O Brasil e sua relação com o global

- O Brasil e sua posição no mundo globalizado;

- Os conflitos geopolíticos e as relações brasileiras (do território marítimo, aéreo e terrestre).

- O Meio ambiente e os enfoques globais: a questão da Amazônia e a água.

Objetivos específicos:

- Compreender como a realidade vivida está inserida nos principais fenômenos geográficos;

- Conhecer o Brasil e seus principais aspectos sociais, políticos, físicos e culturais; 
- Compreender, analisar e identificar os principais pontos da formação do território e da paisagem do nosso Brasil e suas mudanças e permanências atuais;

- Utilizar os conhecimentos cartográficos para localizar e analisar a formação do território brasileiro;

- Analisar as principais característica do processo de regionalização do Brasil e sua importância no contexto atual;

- Identificar as diversas formas de analisar as regiões brasileiras tendo como objetivo reconhecer as principais diferenças regionais e seus aspectos físicos, sociais, políticos, culturais e econômicos mapeando essas;

- Analisar a formação do espaço rural, urbano e industrial e compreender a relação entre eles;

- Analisar a importância dos transportes na transformação e no uso do espaço urbano brasileiro;

- Identificar os processos tecnológicos na mudança territorial brasileiro;

- Identificar o processo de crescimento da população no Brasil e como sua cultura influenciou nas diversas manifestações na paisagem;

- Compreender as migrações e como se configurou a dinâmica dos espaços;

- Identificar as principais formas de trabalho tanto no campo como na cidade e as suas devidas inter-relações territoriais;

- Compreender a evolução geológica e do relevo brasileiro e sua dinâmica na construção das paisagens brasileiras;

- Compreender os diferentes climas decorrentes no Brasil, como a dinâmica da atmosfera e a localização influenciam para isso;

- Analisar e identificar os processos antrópicos que modificam e devastam o meio ambiente brasileiro;

- Compreender a dinâmica das águas no Brasil e como são utilizados para fins lucrativos;

- Identificar os principais ecossistemas presentes no espaço brasileiro e relações com os outros elementos mencionados acima;

- Analisar como o Brasil está posicionado nas relações geopolíticas mundiais;

- Identificar os principais processos geopolíticos no Brasil como a questão do mar territorial, o espaço aéreo e suas fronteiras;

- Analisar a questão do meio ambiente, a luta pelo cuidado com a Amazônia e a questão da água potável como recurso escasso. 
Disciplinas Integradas - História, Geografia, Arte, Matemática, Ciência e Língua Portuguesa.

$\mathrm{Na} 7^{\text {a }}$ série priorizar a análise do Espaço Geográfico do Brasil, mas estabelecendo comparações com outros países, de forma a contextualizar, dando enfoque na escala local, regional, nacional e global.

\section{Regionalização Mundial dos Continentes e das Américas}

\section{As diferentes formas de representar o mundo e as Américas}

O lugar americano no mundo

- As diferentes horas do mundo: o fuso horário;

- O posicionamento das Américas em relação ao espaço mundial;

- A regionalização e as diferentes maneiras de interpretar os aspectos físicos, econômicos, culturais e políticos;

- As diferentes paisagens que englobam o processo de formação do continente americano;

As dinâmicas globais e as transformações dos continentes e das Américas

- Conceito de civilização, sociedade e cultura;

- Espaço Capitalista e Socialista;

- Ricos e Pobres - a concentração da riqueza.

A estrutura e as disputas geopolíticas nas Américas

- Os principais blocos econômicos das Américas e suas inter-relações mundiais;

- Os EUA e sua soberania econômica - as grandes transnacionais;

- A questão mundial do narcotráfico;

- A organização territorial dos blocos do poder (aspectos bélicos, nucleares e econômicos);

- A questão ambiental e o jogo político. 
Objetivos específicos:

- Dominar todos os elementos tratados tendo como perspectiva fazer interrelações com o seu espaço vivido;

- Conhecer as diferentes formas de aprender as horas no mundo;

- Dominar as localizações geográficas das Américas perante o espaço mundial;

- Distinguir as diferentes formas de analisar a regionalização do continente americano e seus principais aspectos: físicos, sociais, econômicos, culturais e políticos;

- Reconhecer as principais formas das atividades econômicas (indústrias e agrários);

- Analisar as diferentes paisagens que formam o continente americano e sua importância para a economia mundial e suas áreas turistas;

- Compreender como se originam as principais civilizações mundiais e americanas formando diferentes sociedades com culturas que se expressam tanto espacialmente como se torna uma mercadoria na vida cotidiana;

- Identificar territorialmente a formação do espaço capitalista e socialista, analisando suas implicações no passado para compreender as mudanças na atualidade;

- Relacionar as diferenças regionais e as concentrações da riqueza pelo mundo e nas Américas;

- Analisar e identificar os principais blocos econômicos do continente americano e relacionar o contexto geopolítico atual entre eles e o espaço mundial;

- Reconhecer as relações de poder dos EUA e as transnacionais que operam em diferentes pontos do espaço mundial;

- Compreender como a rede do narcotráfico se organiza nesse espaço;

- Analisar a organização dos blocos de poder e suas influências nas guerras, na distribuição do armamento e na economia;

- Compreender as interferências geopolíticas na questão da conservação ambiental.

Disciplinas integradas: História, Geografia, Arte, Matemática, Ciência e Língua Portuguesa. 
$\mathrm{Na} 8^{\text {a }}$ série enfatizar a Geografia do Mundo, tendo em vista as grandes mudanças, resultado do processo da globalização - fazer o aluno entender os fenômenos sociais, políticos, econômicos, culturais e ambientais.

\section{As mudanças do espaço mundial atual}

O Mundo em transformação

- Mundo em transformação: as questões econômicas e os problemas geopolíticos;

- Fim da Guerra Fria e a expansão do capitalismo;

- As novas mudanças territoriais;

- Desenvolvimento e Subdesenvolvimento.

Os outros continentes do espaço mundial

- Documentando o mundo político (mapas, gráficos...);

- A África e suas contradições;

- A Europa e as mudanças após o fim da guerra fria;

- A Ásia e as transformações e disputas no Oriente;

- A Oceania: um espaço ainda a conhecer

A questão do consumo mundial e os países emergentes

- A concentração de riquezas - globalização, circulação e consumo de mercadoria e capital;

- Países emergentes e a importância dentro do contexto geopolítico mundial (Questão da China, dos Tigres Asiáticos);

- Consumo e a degradação ambiental.

Objetivos específicos:

- Reconhecer as transformações decorrentes no espaço mundial atual e suas interfaces com o espaço brasileiro;

- Analisar as principais questões econômicas e a organização dos blocos regionais; 
- Identificar os diferentes problemas geopolíticos e suas interferências no espaço mundial;

- Reconhecer como o fim da Guerra Fria e a expansão do capitalismo reorganizaram o espaço mundial;

- Analisar e mapear essas novas territorialidades mundiais;

- Compreender as relações de desenvolvimento e subdesenvolvimento no mundo atual e suas implicações;

- Mapear e identificar outros continentes nesse espaço mundial e verificar sua importância dentro dele;

- Analisar como o continente africano se insere nesse novo contexto global, seu processo cultural e territorial;

- Identificar e associar o continente europeu e suas mudanças territoriais pósguerra fria;

- Compreender as diferentes maneiras de mapear e organizar o continente asiático, as disputas territoriais no Oriente Médio, as condições geopolíticas dos países alinhados;

- Analisar o processo de desenvolvimento da Oceania, os seus principais países: Austrália e Nova Zelândia;

- Identificar a concentração da riqueza mundial e a produção do consumo e sua organização espacial;

- Analisar a importância dos países emergentes na economia e no jogo político mundial;

- Compreender o processo de degradação ambiental, a tentativa do desenvolvimento sustentável para garantir o consumo mundial.

Disciplinas integradas: História, Geografia, Arte, Matemática, Ciência e Língua Portuguesa.

\section{Cartografia no Ensino Fundamental}

O processo cartográfico e a própria alfabetização desenvolvem as habilidades de leitura de mapas e a formulação de questionamentos, confrontando com a realidade, promovendo a iniciativa na busca de informações (projeto de pesquisa, estudo do meio) e que permite a leitura de acontecimentos, fatos e fenômenos geográficos. 
Segundo Simielli (1993), a importância de se trabalhar com a alfabetização cartográfica, é oferecer ao aluno condições de trabalhar com análise/localização/ correlação. A alfabetização cartográfica inicia:

- Alfabeto cartográfico (ponto, linha, área);

- Construção da noção de legenda;

- Lateralidade (referências, orientações);

- Trabalhar com mapas, cartas e plantas;

- Maquetes (representação tridimensional) verificar diferentes formas topográficas, as diferentes altitudes, sempre procurando correlacionar com várias outras informações;

- Croquis (representação bidimensional);

- Rigor nas representações (símbolos e convenções cartográficas);

- Aluno crítico;

- Aluno mapeador e consciente.

\section{Importância dos Materiais ou Recursos Didático/Pedagógico}

Os materiais ou recursos didáticos são importantes no processo de aprendizagem do aluno. Eles são suportes para que os professores possam desenvolver atividades que envolvam o conhecimento. Conforme Zabala (1999: 168) "consideramos materiais curriculares aqueles meios que ajudam os professores a responder aos problemas concretos que as diferentes fases dos processos de planejamento, execução e avaliação lhes apresentem". De forma que esses materiais ou recursos auxiliam o propósito do professor em ter um suporte que o possibilite trabalhar com os aspectos pedagógicos e dinâmicos com o aluno.

Dentro desse universo temos vários recursos a serem trabalhados, podemos citar alguns relevantes para a aprendizagem da disciplina.

- Imagem - O uso da percepção visual é um processo mental fundamental para o ensino de Geografia, pois trabalhamos com a paisagem, o espaço com os objetos que nos cercam, ou seja, com o concreto e com o abstrato ao mesmo tempo, no qual o que é visível tem que ser olhado com uma visão crítica. Trabalhar com a observação, comparação, descrição, interpretação; utilizando fotografias, ilustrações, mapas e imagens em geral 
propiciam situações de aprendizagem interessantes e prazerosas na sala de aula;

- Música - o uso de músicas no decorrer das discussões é interessante para dinamizar as aulas. O interessante é que se ouça a música em sala como parte da atividade. Com o uso dessa linguagem podemos abordar pedagogicamente as letras por meio de análise/reflexão de contextos sociais e geográficos. Atividades que possibilitem a tradução da linguagem musical em dramatização, desenho, poesia, paródia, slogan e etc, são ricas e facilitam o processo contínuo da avaliação;

- Suporte da multimídia (vídeo, TV, DVD, CD, aparelho de som) - são instrumentos que trazem uma boa contribuição para o ensino de Geografia, pois ao selecionar um tema coerente com as salas unem-se imagem com a linguagem geográfica. A interação entre estes suportes garante a busca de informações e de trabalho mais sistematizados e ricos. A utilização de filmes relacionados ao tema é importante, pois oferece uma linguagem objetiva e próxima dos alunos. Promove também uma outra dinâmica em sala, já que a interpretação da imagem, da linguagem e da abordagem do autor expressa uma forma de ser dos personagens, do cenário e da própria fala;

- Biblioteca - espaço privilegiado de fonte de pesquisa, momento de leitura e reflexão das obras relacionadas aos temas estudados em sala de aula;

- Sala de informática - promove o aprendizado por meio da investigação, oportunizando o envolvimento dos alunos ao acesso à tecnologia. A informática amplia as possibilidades de aprendizagem na sala de aula, ao fazer o uso do computador para pesquisa, publicação e comunicação.

- O livro didático - mais instrumento utilizado na escola. É de suma importância para a utilização na pesquisa dos temas discutidos em sala de aula.

\section{Avaliação}

É um precioso meio pelo qual o professor pode acompanhar as manifestações de aprendizagem de seus alunos, examinar a validade de sua prática pedagógica e, ainda, a sua própria atuação docente. 
A fim de respeitar as diferentes formas de expressão, que um grupo heterogêneo de alunos apresenta, os professores podem se valer de vários instrumentos de avaliação. Entre eles estão a observação e o registro da participação de cada um de seus alunos que envolvam expressão oral e escrita.

Avaliar os conteúdos conceituais, procedimentais e atitudinais.

A avaliação dos conteúdos conceituais é identificar o domínio e utilização das informações com a realização de pesquisa, debates, elaboração e interpretação de textos, valorizando o desenvolvimento cognitivo e não a simples memorização.

A avaliação dos conteúdos procedimentais é verificar se os alunos estão compreendendo e utilizando, de forma adequada os instrumentos da disciplina para a produção e leitura de mapas, gráficos, tabelas, etc.

A avaliação dos conteúdos atitudinais considera como o grupo de alunos se comporta diante da compreensão mais aprofundada da realidade, desenvolvendo uma postura solidária, participativa e crítica. Devem ser avaliadas permanentemente as participações dos alunos, o interesse pelos novos conteúdos, o relacionamento com o grupo, o respeito às diferenças entre pessoas e grupos sociais.

A avaliação é um instrumento de feedback contínuo, devendo ser um elemento integrador e não de coerção, visando a corrigir possíveis distorções no processo de ensino aprendizagem.

As avaliações, pautadas no processo de construção, devem ser provas discursivas (com e sem consultas), trabalho de pesquisas, elaboração de entrevistas, montagem de histórias em quadrinhos (quadrinização de músicas), elaboração e análise de mapas, debates, exercícios reflexivos, observação e análise de fotos e montagem de textos, pesquisa de campo e preparação de relatório de filmes e atividades de campo.

\section{Conclusões:}

A construção desta proposta curricular nos possibilitou refletir a importância de sabermos selecionar e organizar não só os conteúdos, mas, como a Geografia deve exercer seu papel dentro do processo educativo.

Outro ponto importante foi a nossa produção coletiva, pois, com ela, podemos realizar e articular idéias que possibilitem a pensar em nossa prática e também no nosso conhecimento. 
Queremos trabalhar cada vez mais para estimular o conhecimento do nosso aluno sobre a Geografia e as suas representações espaciais capacitando-nos sempre na busca de eficazes alternativas ao nosso processo de ensino.

\section{Referências Bibliográficas:}

BRASIL, Secretaria de Educação Fundamental. Parâmetros Curriculares Nacionais: Geografia, Brasília: MEC/ SEC, 1997.

CAVALCANTI, Lana de Souza. Propostas curriculares do Ensino de Geografia: algumas referências de análise. In: Associação de Geógrafos Brasileiros. As transformações no mundo da Educação: Geografia, Ensino e Responsabilidade sócia. São Paulo: AGB-Terra Livre, no 14 jan/jul, 1999, 111-128 p.

COLL, César. Psicologia e currículo: uma aproximação psicopedagógica à elaboração do currículo. São Paulo: Ática, 1996. 65-152 p.

SANTOS, Milton. Por uma Geografia nova Da crítica da Geografia a uma Geografia Crítica. São Paulo: EDUSP, 2002.

SIMIELLI, Maria Elena Ramos. Os primeiros mapas: como entender e construir. São Paulo: Ática, 1993.

ZABALA, Antoni. A função social do ensino e a concepção sobre os processos de aprendizagem: instrumentos de análise. IN: A Prática Educativa: como ensinar. Editora Artmed, 1999. 2a ed., p. 27-53.

. Os materiais curriculares e outros recursos didáticos. IN: A Prática Educativa: como ensinar. Editora Artmed, 1999. 2ª ed. 167-194 p.

\subsubsection{Alguns elementos da Proposta Curricular organizada pelos professores da Escola da Zona Sul}

\section{Introdução}

A Geografia tornou-se uma ciência autônoma a partir do século XIX. Durante o período pós-guerra passou por uma crise entre os que queriam como ciência da sociedade, e os que a tomavam como ciência da natureza. Desta contradição, as teorias do materialismo histórico foram sendo inseridas pelos geógrafos "críticos". Quando chegou a escola básica na década de 80, rompeu-se com o ensino 
conteudista, do saber neutro e da paisagem como espetáculo (apesar de ainda existirem essas concepções na escola).

Hoje, a Geografia está redefinida como ciência social. O espaço do homem é importante para o desenvolvimento da história. A Geografia é uma ciência atual e o seu objetivo principal é contribuir para o entendimento do mundo, da apropriação de lugares realizados pelos homens, pois é através da organização do espaço, que os homens dão sentido aos arranjos econômicos e aos valores sociais e culturais construídos historicamente.

Agora é o momento de se estruturar um currículo onde o estudo das ciências, e principalmente, o das Humanidades seja complementar e não excludente. Na tentativa de uma síntese entre o humanismo, a ciência e a tecnologia, deve-se ressaltar a relevância de adequação das ciências geográficas no cotidiano, o que requer do indivíduo: um raciocínio lógico, o desenvolvimento do espírito crítico, estabelecimento das capacidades de pesquisa e a busca por coisas novas.

Para que isto aconteça deve haver o estabelecimento de técnicas e estratégias pedagógicas renovadas e um currículo atrativo não só para o professor, mas também para aquele que apreende.

O ensino de Geografia considera a realidade vista pelo conjunto, e nas suas alterações, portanto, representa o elemento ativo no processo histórico. A compreensão da realidade refletirá sobre a análise da dinâmica social, da natureza e de suas relações e inter-relações. Portanto, o currículo no seu contexto geral mostra, uma ciência geográfica, comprometida em tornar o mundo compreensível, explicável e passível de transformações para os alunos. O currículo deve adequar-se a essa mudança: a importância de uma cidadania brasileira consciente e participativa que inculca o conhecer e o agir em seu próprio espaço.

\section{Objetivos da Geografia na escola}

O objetivo da Geografia é explicar e compreender as relações entre a sociedade e a natureza, e como ocorrem as apropriações destas. Tem de trabalhar com diferentes noções espaciais e temporais, com fenômenos sociais, culturais e naturais que são características de cada espaço permitindo uma compreensão processual e dinâmica de sua constituição. 
O ensino de Geografia, conforme os PCNs, pode levar os alunos a compreenderem de forma mais ampla, a realidade, possibilitando que nela interfiram de uma maneira consciente e propositiva.

A Geografia serve para tudo aquilo que é necessário ao indivíduo em entender a produção e a transformação do seu espaço vivido, as relações deste espaço vivido com outros espaços, os diferentes graus de conexões entre os fenômenos naturais aos demais fenômenos antrópicos nas várias escalas (da local à internacional).

Também objetiva o desenvolvimento de mecanismos para a percepção do sujeito; o "saber olhar seu próximo entorno", adequando os meios, instrumentos e demais recursos materiais para facilitação da compreensão e descrição.

A Geografia, escrita nos PCNs, contribui para pensar o espaço enquanto uma totalidade na qual passa todas as relações cotidianas e por onde se estabelece com as redes sociais. No ensino Médio, o aluno deve construir competências que permitam a análise do real, revelando as causas e os efeitos, a intensidade, a heterogeneidade e o contexto espacial dos fenômenos que configuram cada sociedade.

Conforme Helena Copetti Callai existem três razões para estudar Geografia: a primeira, para conhecer o mundo e obter informações; a segunda considera a Geografia a ciência que analisa, estuda e tenta explicar (conhecer) o espaço, produzido pelo homem; por fim, a terceira, vê a formação do homem como cidadão.

"A Geografia que o aluno estuda deve permitir que lê se perceba como participantes do espaço que estuda, em que os fenômenos que ali ocorrem são resultados da vida e do trabalho dos homens que estão inseridos num processo de desenvolvimento".

A Geografia deve auxiliar, essencialmente, na formação global do indivíduo como um cidadão, que atua social, cultural, ambiental e politicamente e que define/redefine valores na sociedade.

\section{Objetivos específicos}

Reconhecer os fenômenos ligados ao espaço, não só a partir da dicotomia natureza - sociedade, mas tomando-os como produtor das relações que orientam seu cotidiano, definem seu "lócus espacial ” e o interligar a outros conjuntos espaciais. 
Reconhecer as contradições e os conflitos econômicos, sociais e culturais, para avaliar a qualidade de vida, ponde-se em busca de uma organização social mais igualitária.

Fazer leituras de imagens, de dados e de documentos de diferentes fontes de informações, de modo a interpretar, analisar e relacionar informações sobre o espaço geográfico e as diferentes paisagens.

Saber utilizar a linguagem cartográfica para obter informações e representar as espacialidades dos fenômenos geográficos.

Valorizar o patrimônio sócio-cultural e respeitar a sociodiversidade, reconhecendo-a como um direito dos povos e indivíduos, e um elemento de fortalecimento da democracia.

\section{Objetivos das Competências e Habilidades:}

O desafio atual da educação é a formação ético humanística e tecnológicacientífica do aluno diante do mundo em que vive, as diferentes concepções educativas que exigem a conexão entre a informação, formação e criatividade dos alunos e dos professores.

O professor deve ser criativo, articulador e parceiro, refletindo sua prática constantemente, e desenvolver as competências necessárias para que o aluno seja um sujeito-histórico que detenha um conhecimento compatível para lidar com o desenvolvimento tecnológico constituído por uma formação crítica.

Só através do desenvolvimento das competências será capaz de existir este aluno-cidadão.

Para Perrenoud (2002) a competência é "a capacidade de mobilizar os diversos recursos cognitivos". Só com o estabelecimento de hipóteses construídas pode-se enfatizar a situação-problema. Os dispositivos necessários para o desenvolvimento dessa competência são requeridos na relação entre a aprendizagem e o saber, criando a mobilização do conhecimento, elencando uma série de equações mentais, numa seqüência de situações e de experiências formadoras e vivenciadas pelo ato, num processo de aprendizagem incentivadora e não dominadora.

As competências e as habilidades de acordo com o ensino de Geografia seriam: 
- Ler, analisar e interpretar os códigos específicos da Geografia (Mapas, gráficos, tabelas e etc.), considerando-os como elementos de representação de fatos e fenômenos espaciais e/ou espacializados;

- Reconhecer e aplicar o uso das escalas cartográfica e geográfica, como forma de organizar e conhecer a localização, distribuição e freqüência dos fenômenos naturais e humanos;

- Compreender e aplicar no cotidiano os conceitos básicos da Geografia;

- Reconhecer os fenômenos espaciais a partir da seleção, comparação e interpretação, identificando as singularidades ou generalidades de cada lugar, paisagem ou território;

- Selecionar e elaborar esquemas de investigação que desenvolvam a observação dos processos de formação, transformação dos territórios;

- Analisar e comparar, de forma interdisciplinar, as relações entre preservação e degradação da vida no planeta;

- Identificar, analisar e avaliar o impacto das transformações naturais, sociais, econômicas, culturais e políticas no seu "lugar-mundo". (PCEM);

- Extrair, analisar, interpretar, estabelecer, explicar, analisar, reconhecer, contextualizar, inferir, julgar, utilizar, contribuirão para que o aluno desenvolva suas competências, baseado na mediação do professor, porque para cada conteúdo corresponde uma habilidade e competência específica.

\section{Objetivos dos Conceitos}

A seleção dos conceitos está pautada na liberdade de ação, desde que sirvam como alicerce para o desenvolvimento do processo ensino e aprendizagem.

A sua utilização proporcionará a "abertura" maior para o conhecimento do aluno com a intenção de se atingir os objetivos propostos. Representará a aplicação das habilidades e competências, e a compreensão dos fenômenos geográficos.

Entendemos que os principais conceitos que permitirão o entendimento da Geografia são:

Paisagem: Para Ab'Saber (2003) "A paisagem é a herança dos processos fisiográficos e biológicos, e patrimônio coletivo dos povos que historicamente as herdaram como território de atuação de suas comunidades". 
Representa uma discussão concreta do mundo, possui significados construídos pela percepção que se tem dela. (PCN- Fundamental, 1997).

O conceito de paisagem deve ser mostrado ao educando como além da paisagem bucólica e sim a cultural, a cotidiana.

Este conceito deve ser trabalhado por meio de imagens, observação e criação das mesmas pelos educandos.

Território: Para Sousa (1995) "Um espaço definido e delimitado por e a partir de relações de poder".

Este conceito deve ir além das discussões territoriais-espacias tais como país, nação (localização no mapa-mundi). O território deve ser utilizado nas relações de poder, de posse e de domínio, de ações político-sociais dos países.

Lugar: PCN-Médio: "Porção do Espaço apropriado para a vida, o qual é vivido, reconhecido e criado de identidade, é nele que se dá a cidadania e as relações de ausência e conflito, de dominação e de resistência".

É o espaço mais próximo do aluno. Mostra as singularidades e peculiaridades, através da análise das relações sociais-culturais deste local.

Espaço: Para Santos (2002) "deve ser considerado como um conjunto de relações realizadas através das funções e de formas, que se apresentam como testemunho de uma história escrita por processos do passado e do presente. O espaço é um verdadeiro campo de forças cuja aceleração desigual".

Deve ser mostrado cartograficamente através de mapas temáticos, evidenciando as transformações sociais, políticas e tecnológicas, demonstrando o espaço local, regional, mundial, nas suas diferentes escalas.

Natureza: Espaço a ser modificado, transformado pelo homem de acordo com fatores políticos e econômicos.

Escala: Para Castro (1995): "Noção de proporção, área e continuidade. É uma forma de representar o espaço, definindo uma realidade percebida/concebida, um conjunto de representação coerentes e lógicas, que substituem o espaço conservado. Utilizar as diferentes escalas: local, regional, mundial". 
Mapa: Para Almeida (2003): "Os mapas são produzidos a partir da definição de uma malha de coordenadas geográficas que permitem a localização precisa de qualquer ponto sobre a Terra. Os mapas são importantes ferramentas para uma compreensão crítica do espaço".

Mostrar os mapas antigos (primeiros mapas), mapas temáticos, evidenciando as transformações sociais, políticas e tecnológicas. Mostrar os espaços locais, regionais, mundiais.

Evidenciar a localização, correlação, síntese e representação dos mapas, numa escala gradual de ensino-aprendizagem.

Urbano: Para Carlos (1999) "É na cidade que há a centralidade na troca de produtos no espaço urbano supera a centralidade, já que os lugares escolhidos para o comércio e multiplicar as situações estratégicas".

Rural: Espaço cada vez mais mecanizado, estruturado para s relações comerciais no espaço urbano.

O conhecimento destes conceitos fará com que o aluno tenha uma perspectiva ampla sobre as diferentes aplicabilidades no que concerne ao conhecimento e ao saber. É importante também, para que se façam uma relação com a vida cotidiana. A geografia, fazendo uso desses conceitos, conseguirá trazer à tona as questões que ajudarão o homem a pensar o seu espaço.

\section{Objetivos dos conteúdos}

Quaisquer que sejam os conteúdos deve-se ter em mente o foco principal, que é desenvolver a capacidade do aluno (sujeito/indivíduo) em observar, localizar, estabelecer relações, interpretar, interagir e conceituar.

Os conteúdos devem respeitar o grau de maturidade/cognitivo, avançando do simples para o mais complexo. A partir da escala local vamos percorrer o regional, o nacional e o global articulando esses elementos. 


\section{Desenvolvimento da Estrutura Geral dos conteúdos por séries}

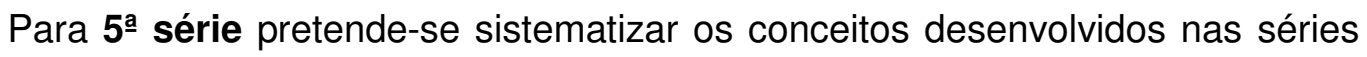
iniciais: proporção, legenda, orientação, direção, representação, cidade, campo, indústria e natureza.

Conceitos: Paisagem, Transformação, Natureza, Território e Lugar, Alfabetização Cartográfica.

\section{A Geografia do Cotidiano}

A localização do espaço:

- Pensando a escala local ao mundial (bairro, município, Estado, País);

- As diferentes paisagens e suas transformações;

- Os diferentes pontos de localização entre o vivido e o mundial;

- A dinâmica do espaço rural e do espaço urbano;

- As diversidades regionais da relação campo/cidade.

O meio físico e sua transformação antrópica:

- Onde pisaríamos: a formação da crosta terrestre;

- As transformações do relevo e a influência do homem;

- As diferentes maneiras de interpretar o clima no campo e na cidade;

- A questão da água e o uso pela humanidade.

Objetivos específicos:

- Promover a compreensão da geografia enquanto disciplina importante para interagir o universo vivido do aluno e a relação com ao espaço mundial;

- Identificar e reconhecer as diferentes escalas do espaço geográfico;

- Dominar as suas posições mediante o local ao mundial, ou seja, conhecer a sua localização em relação ao bairro, município, estado, país e mundo;

- Diferenciar as diferentes paisagens no espaço, as suas mudanças e permanências mediante as ações da sociedade; 
- Compreender os processos de conceitos relacionados ao campo e a cidade: funções urbanas e rurais;

- Identificar e relacionar as diferentes formas de trabalho no espaço urbano e rural: as atividades agrícolas, o processo industrial, a dinâmica e utilização dos recursos naturais e minerais, o meio de transporte e sua necessidade, 0 turismo e o lazer;

- Analisar os processos migratórios e as territorialidades culturais

- Identificar as diferentes áreas regionais;

- Compreender e analisar como a sociedade se utiliza o meio físico para seu consumo;

- Analisar os principais processos de transformação da crosta terrestre e sua influência na construção do mundo atual (sua camada, tectonismo, vulcanismo, movimentos sísmicos, a formação geológica donde o aluno pisa), tendo a atuação antrópica nessa transformação;

- Reconhecer as diferentes formas de relevo, como os espaços urbanos e rurais se transformaram com a influência do homem (formação geomorfológica - as principais formas no qual o aluno habita, os agentes modeladores e o processo de degradação) e o processo de transformação do solo (como termo físico e como termo urbano);

- Compreender a dinâmica atmosférica e entender as diferentes mudanças dos climas locais devido ao processo antrópico (a ilha de calor, o efeito estufa, a chuva ácida,...);

- Analisar a dinâmica da água, sua importância para o surgimento das cidades, para a sociedade e como a poluição afeta o seu uso;

- Compreender a interferência do homem no processo de degradação ambiental e a conscientização dos alunos para essa questão.

Articulação com os temas transversais: Meio Ambiente e Cidadania.

Para 6a série, pretende-se sistematizar conceitos relativos ao Território Brasileiro, com os aspectos da Geografia Física (relevo, vegetação, clima), Política (ocupação e demarcação do território) e economia (agropecuária, indústria e comércio), além de desenvolver tópicos sobre a heterogeneidade da população brasileira.

Conceitos: Paisagem, Sociedade, População, Território, Natureza, Região, Leitura Cartográfica. 


\section{O Espaço Brasileiro: origens e atualidades}

A identidade do Brasil:

- Formação território-histórico e cultural do espaço brasileiro;

- Cartografando o território brasileiro;

- As diferentes regionalizações do espaço brasileiro.

As transformações do espaço brasileiro: o espaço rural e urbano e as interfases com a política, a cultura, a migração a economia e o meio físico:

- O espaço rural e suas diversas atividades (o processo da Terra como mercadoria no Brasil, as diversas atividades agrícolas, atividades rural-urbano, as migrações, a política no campo e as diversas lutas);

- O espaço urbano e as suas transformações (o processo de mudanças na cidade, o processo industrial e suas localizações no espaço geográfico brasileiro, o movimento migratório);

- As diversas relações de trabalho entre o rural e o urbano;

- A migração e a cultura dos diferentes povos que influenciaram na construção da nação brasileira (a influência do negro, do índio, do branco e do asiático);

- O meio físico e as interferências antrópicas: o relevo, a hidrografia, o clima, a geologia e a vegetação do território brasileiro.

O Brasil e as relações geopolíticas

- O Brasil no mercado mundial;

- A questão do narcotráfico;

- A questão das fronteiras;

- A questão Amazônica e a biopirataria.

Objetivos específicos:

- Conhecer e analisar a formação territorial e cultural do espaço brasileiro;

- Compreender e utilizar os conhecimentos cartográficos para localizar e analisar o processo de formação do território brasileiro;

- Identificar as diversas formas de analisar regionalmente o Brasil; 
- Analisar o processo de formação do espaço rural, urbano e industrial compreendendo as inter-relações entre eles;

- Identificar as diversas relações de trabalho entre a cidade e o campo;

- Conhecer a dinâmica do processo migratório e cultural;

- Analisar a questão do preconceito dos imigrantes nordestinos e suas territorialidades;

- Compreender a evolução geológica e geomorfológica do relevo brasileiro;

- Analisar a dinâmica atmosférica do Brasil e a influência do homem;

- Compreender a dinâmica hidrográfica no espaço brasileiro e sua utilização;

- Identificar os principais ecossistemas presentes no espaço brasileiro e sua devastação;

- Analisar as relações geopolíticas do Brasil mediante ao mercado mundial;

- Identificar e compreender a relação do narcotráfico;

- Dominar os elementos relacionados à questão da fronteira no Brasil;

- Compreender a Amazônia e a exploração da biopirataria.

Articulação com os temas transversais: Multiculturalismo, Cidadania, Saúde.

$\mathrm{Na} 7^{\mathbf{a}}$ série, pretende-se construir uma visão abrangente a respeito da América, sob os mais diversos pontos de vista: desde as paisagens e aspectos culturais, até a história de sua função e formação e as atuais características da economia e da organização social. Com o mesmo objetivo são estudados os diversos critérios de classificação dos países e a formação dos blocos econômicos.

Conceitos: Paisagem, Sociedade, Trabalho, Indústria, Agrária, Território, Desenvolvimento e subdesenvolvimento, Natureza, Região, Leitura Cartográfica.

\section{O continente Americano e suas relações com o espaço mundial}

A localização espacial das Américas no globo mundial

- O mundo e seus múltiplos horários;

- A localização geográfica americana;

- A formação histórico-territorial do continente americano;

- A formação do meio físico. 
- O desempenho econômico americano: os seus interesses;

- Os blocos regionais e suas implicações políticos e econômicos;

- Os fluxos migratórios e a lógica dos movimentos.

As Américas e as interfases com a Geopolítica Mundial

- Cuba: ainda alinhado?;

- EUA e sua homogeneização do mercado global;

- A questão do narcotráfico;

- A questão energética.

Objetivos específicos:

- Identificar os diferentes horários no mundo;

- Dominar e mapear as localizações geográficas do continente americano em relação ao mundo e as suas diferentes divisões;

- Analisar o processo de regionalização do continente americano e seus principais aspectos;

- Compreender a importância da formação histórico-cultural e territorial do continente para as características dos diferentes povos e as suas representações na paisagem americana;

- Entender a formação do meio físico e seus principais aspectos: a parte geológica e as influências das diferentes formações do relevo, o clima e as poluições atmosféricas, a água e o seu uso, as formações vegetais;

- Analisar a conjuntura econômica do continente em face do processo capitalista e socialista;

- Identificar e reconhecer o processo de construção dos blocos regionais e as devidas interferências no mercado econômico do continente e mundial;

- Interpretar e relacionar o processo migratório em diversos países do continente e a importância dos imigrantes para a economia e a cultura desses;

- Dominar as diversas conjunturas que une o continente americano a geopolítica mundial;

- Compreender porque Cuba é uma exceção nas Américas e a diferença econômica e política; 
- Analisar o domínio dos EUA frente ao mercado mundial;

- Analisar a inter-relação do narcotráfico mundial e suas diversas redes;

- Identificar a importância do controle dos recursos energéticos para obtenção de lucros econômicos no espaço mundial (como intervenção em países principalmente no Oriente Médio).

$\mathrm{Na} 8^{\mathbf{a}}$ série, pretende-se que o aluno compreenda a diversidade do mundo em vários aspectos, valorizando a multiplicidade de culturas, religiões e etnias e observando de maneira crítica as desigualdades econômicas entre as nações.

Conceitos: Paisagem, Sociedade, População, Estado, Fronteira, Nação, Território, Natureza, Região, Tecnologia, Circulação, Leitura Cartográfica.

\section{A Espacialização do Mundo Atual}

A Velha Ordem Mundial

- O expansionismo capitalista;

- Os conflitos mundiais;

- A Guerra Fria.

A Nova Ordem Mundial

- Pós guerra-fria: O mundo globalizado

- A nova territorialidade mundial

- A circulação de mercadoria, de informação e de capital financeiro nos diversos territórios;

- A tecnologia, as redes e as empresas transnacionais;

- A utilização dos recursos naturais;

- A globalização e fragmentação: os incluídos e os excluídos.

A configuração espacial dos continentes:

- Fronteiras, Estados e Nações no Mundo;

- A Europa no contexto mundial;

- Uma expedição pela África; 
- A Ásia e seus diferentes aspectos culturais, políticos, religiosos e econômicos: Oriente Médio, Índia, Federação Russa, China, Tigres Asiáticos e Japão;

- Oceania.

Objetivos específicos:

- Compreender como o expansionismo capitalista acelerou o processo de transformação espacial em todo o mundo;

- Identificar e dominar os principais aspectos geográficos dos principais conflitos mundiais: As guerras mundiais;

- Mapear e correlacionar os diferentes territórios construídos pelos conflitos;

- Relacionar os diversos conflitos para o surgimento da Guerra e compreender a ideologia capitalista e socialista;

- Analisar as principais características mundiais no mundo pós-guerra fria;

- Mapear as novas territorialidades mundiais e identificar as diferentes mudanças;

- Identificar e relacionar os acontecimentos econômicos e analisar o desenvolvimento circulatório das mercadorias, do aumento do uso da informação e comunicação e do capital financeiro depois do pós-guerra;

- Analisar as inter-relações da tecnologia e as relações em rede para a formulação e aumento das empresas transnacionais no espaço mundial atual;

- Identificar a importância dos recursos naturais para a exploração do mercado mundial;

- Compreender e conceituar o significado das fronteiras, dos estados e das nações nos territórios mundiais;

- Localizar os continentes e suas diferenças regionais;

- Identificar os principais aspectos do meio físico esses continentes;

- Analisar a questão da Europa e seu contexto na atualidade;

- Relacionar a importância da cultura, da política, das guerras civis e dos recursos naturais e minerais para o continente africano, bem como a sua territorialidade forjada;

- Dominar a importância do crescimento asiático e as diversas contradições culturais, sociais, políticas e econômicas, principalmente em áreas de conflitos constantes: Oriente Médio e os países em desenvolvimento: Coréia do Sul, China e Índia e o Japão;

- Analisar o processo de desenvolvimento da Oceania. 


\section{Os Materiais/Recursos didáticos:}

Os recursos didáticos têm como função auxiliar o professor, em um primeiro momento e também o aluno, em outro momento, na busca dos elementos necessários para o desenvolvimento do processo de ensino e aprendizagem na busca do saber e da aplicação prática.

Eles são meios/instrumentos variados que possibilitam múltiplas abordagens para um mesmo assunto/conteúdo/propósito abordado. Os referidos recursos permitem uma flexibilidade no processo educativo, permitindo atingir os objetivos propostos.

- Cadernos de anotações - num primeiro momento sua justificativa deve-se a uma indução à organização dos registros oferecidos pelo professor e num segundo momento, a abrir alternativas de registros individuais/pessoais conforme o grau de interesse e necessidade no desenrolar dos assuntos. Em um outro momento, serve como instrumento de avaliação do aluno do seu próprio desempenho;

- Livro básico da disciplina - instrumento de apoio para o acompanhamento dos assuntos/conteúdos a serem desenvolvidos e também dos já desenvolvidos. Não deve ser visto como uma única "verdade", cabendo ao aluno outras referências;

- Mapas - instrumento necessário para ilustrar. Com sua linguagem especificam os assuntos/temas que serão abordados. Recurso fundamental para trabalhar/desenvolver a habilidade/competência de localização, orientação e representação bem como desenvolver o conceito de leitura cartográfica;

- Paradidáticos - instrumentos de apoio para alimentar o conhecimento dos vários temas, possibilitando novas linguagens e enfoques com 0 aprendizado de diferentes expressões e suas aplicações num projeto transdisciplinar. Permite o contato com diferentes visões acerca de um mesmo tema;

- Recurso multimídia - permite a visualização por meio das imagens/dados dos assuntos tratados, também interação com novas tecnologias/programas, que permitem combinações, arranjos e adaptações para o desenvolvimento das atividades propostas; 
- Visita de campo - permite o contato direto com a realidade estudada em sala e a visualização do espaço e suas relações. Permite colocar em prática "alguma" proposta de trabalho já desenvolvida. Proporciona a visualização dos objetos/elementos de estudo com o objetivo de estabelecer as relações existentes entre o pensamento lógico e sua prática;

- Música - é uma demonstração da construção do conteúdo histórico por meio de uma linguagem informal, despretensiosa e simples (acessível). O uso da música no ensino depende do tema e está ligado principalmente à letra. A sua utilização nas aulas de Geografia é uma forma de motivar os alunos e dinamizar a aula. Além disso, a música é uma linguagem que tem ligação com a realidade, possui um contexto histórico, que poderá ser explorada em outras disciplinas: História e Língua Portuguesa, havendo um trabalho interdisciplinar;

- Biblioteca (pesquisas bibliográficas) - é o ambiente do qual o aluno recorre para desenvolver e ampliar seus conhecimentos por meio de diferentes autores, títulos e assuntos.

\section{Avaliação:}

Entendemos avaliação como um processo contínuo ou observação contínua do ensino e aprendizagem. A condição de diagnosticar os problemas relacionados à aprendizagem. Instrumento capaz de apontar se o caminho deve ser mantido ou alterado.

Ao avaliar o processo de ensino e aprendizagem o professor deve estruturar e encaminhar os conteúdos a serem solicitados, estabelecer parâmetros do que precisa ser investigado.

O que se pretende ao avaliar o aluno é obter as respostas dos objetivos estabelecidos para serem atingidos num determinado contexto programático. É necessário oferecer várias opções de desenvolvimento de trabalhos para cada proposta e detectar qual/quais e/são as mais viáveis para cada grupo ou assunto.

Ela não pode ser deter a um único instrumento ou momento. Segundo Coll (1996), a avaliação é um instrumento de controle do processo educacional.

A avaliação deve ser feita em dois momentos distintos, com objetivos distintos: no primeiro momento: avaliar para estabelecer um referencial daquilo que 0 sujeito/indivíduo já conhece, domina ou abstrai.; no segundo avaliar após o 
desenvolvimento do trabalho para identificar seu grau de compreensão, suas dificuldades ou falhas.

A avaliação deve ser contínua, individual ou coletiva. Deve considerar a criatividade do aluno ao dar seu feedback.

Pode-se estabelecer na prática-reflexiva e participativa:

- Problematizar o tema;

- Ter um problema para resolver;

- Deve promover o envolvimento do aluno, ao ver-se desafiado;

- Envolver o aluno de forma que perceba a sua evolução durante o ano (auto-avaliação);

- Trazer a reflexão sobre a participação do professor e do aluno;

- Avaliar cada fase (os pontos positivos e negativos).

\section{Conclusão}

A construção desta proposta curricular tem como objetivo refletir sobre a nossa prática para a realização de um conhecimento que promova ao aluno a compreensão dos fenômenos geográficos.

Queremos destacar a importância de se pensar que tipo de Geografia vamos ensinar, bem como os conteúdos que serão ministrados para que o aluno, ao fim de cada série, compreenda e faça a leitura crítica do mundo em que vive.

O currículo é um "caminho". Novas propostas requerem, antes de tudo, pessoas capazes e abertas às novidades. Esperamos concretizar essa proposta, associando a teoria à prática.

\section{Referências Bibliográficas}

AB' Saber, Aziz. Os domínios de natureza no Brasil: Potencialidades Paisagísticas. SP: Atelie Editorial, 2003. 9 p.

ALMEIDA, Rosângela Doin de. Do desenho ao mapa: iniciação cartográfica na escola. São Paulo: Contexto, 2003.

BEHRENS, Marilda Aparecida. As 10 fases do projeto de aprendizagem colaborativa. (sem referência)

BRASIL, Ministério da Educação. Parâmetros Curriculares Nacionais: Geografia. Brasília - DF. Secretaria de Ensino Fundamental, 1997. 
BRASIL, Ministério da Educação. Ciências Humanas e suas tecnologias. Brasília - DF: MEC, 2001

CARLOS, Ana Fani A. Novos Caminhos da Geografia. São Paulo: Contexto, 1999.

CASTRO, Iná Elias (et alli). O problema da escala. In: Geografia: Conceitos e Teoria. RJ: Bertrand Brasil, 1995. 117-139 p.

CALLAI, Helena Copetti et alli. Grupo, espaço e tempo nas séries iniciais. In: Geografia em sala de aula: práticas e reflexões. Porto Alegre: ED. UFRGS, 2004, 57- $63 \mathrm{p}$.

COLL, César. Psicologia e currículo: uma aproximação psicopedagógica à elaboração do currículo. São Paulo: Ática, 1996. 65-152 p.

PERRENOUD, Philippe. As competências para ensinar no século XXI: a formação dos professores e o desafio da avaliação. Porto Alegre: Artmed, 2002.

SANTOS, Milton. Por uma Geografia nova da crítica da geografia a uma Geografia Crítica-SP; EDUSP, 2002.

SOUZA, Marcelo Lopes de (et alli). O território: sobre espaço e poder, autonomia e desenvolvimento. In: Geografia: Conceitos e Temas. Rio de Janeiro: Bertrand Brasil, 1995, 77-113 p.

ZABALA, Antoni. A função social do ensino e a concepção sobre os processos de aprendizagem: instrumentos de análise. IN: A Prática Educativa: como ensinar. Editora Artmed, 1999. $2^{\text {a }}$ ed., p. 27-53.

Os materiais curriculares e outros recursos didáticos. IN: A Prática Educativa: como ensinar. Editora Artmed, 1999. $2^{\mathrm{a}}$ ed. 167-194 p.

\subsubsection{Análise dos elementos curriculares apresentados}

Os elementos curriculares realizados pelos professores das duas escolas estaduais do município de São Paulo nos trazem alguns aspectos significativos: no desenvolvimento das discussões, a preocupação foi compreender o papel que a Geografia escolar tem nesse processo educativo; a importância desses elementos que nortearão o processo organizacional das aulas na busca do ensino e da aprendizagem do espaço vivido do aluno; a preocupação dos conceitos que permearão o ensino da disciplina e sua importância para a compreensão da Geografia como uma disciplina que procura a intervenção do processo espacial da sociedade; o fundamento dos conteúdos para os professores, sua organização a partir do ponto de vista do grupo; a questão da 
avaliação pertinente ao processo de construção do conhecimento descrito nos conteúdos e dos materiais curriculares a serem utilizados por eles.

Acreditamos que a evolução do pensamento dos professores em relação ao desenvolver teoricamente o currículo, os fizeram refletir sobre a importância que a Geografia tem atualmente e a sua dinamização na aprendizagem. Como veremos adiante, os currículos com exceção dos anos 1982 e 1990, não havia uma explanação específica sobre o desenvolvimento e a importância desses conteúdos no passado. Conforme a pesquisa realizada por nós, o primeiro currículo foi uma transposição do currículo francês e os outros foram descritos por professores de Geografia (no qual a maioria estudou na França e acompanhou um compêndio da época). Nos de 1982 a 1992 os coordenadores de áreas desenvolviam o plano de curso das unidades correspondentes a serem aplicados pelos outros professores.

Os professores procuraram desenvolver os elementos para que os leitores compreendessem a importância de se ensinar Geografia no contexto escolar. Por isso na introdução escrevem o porquê organizar e repensar o que será trabalhado no ano letivo, e os devidos procedimentos que utilizarão conjuntamente para que desenvolvam suas atividades. Mediante isto, os professores da Escola da Zona Leste argumentam que: "O currículo de Geografia deve contribuir para que o aluno aprenda a organizar seu pensamento a partir do seu cotidiano, para depois introduzir o conhecimento científico. Sabemos que para despertar o interesse do estudante pela Geografia, é necessário aproximar o máximo possível, os conteúdos da disciplina em seus aspectos conceituais, procedimentais (como fazer, como proceder?) e atitudinais (solidariedade, cooperação, cidadania e ética), da sua realidade cotidiana".

Cremos que essas concepções sejam importantes para que os próprios professores orientem seus trabalhos em uma produção construtiva do processo de ensino em suas interfaces com a Geografia escolar. Por isso, os objetivos descritos, os alicerçam no direcionamento da disciplina no âmbito escolar, necessários também à escolha dos conteúdos. Ao descrever a importância dessa Geografia, os professores da Escola da Zona Sul, nos faz pensar o porquê dela ainda estar inserido no contexto escolar: A Geografia serve para tudo aquilo que é necessário ao indivíduo em entender a produção e a transformação do seu espaço vivido, as relações deste espaço com outros espaços; os diferentes graus de conexões entre os fenômenos naturais aos demais fenômenos antrópicos nas várias escalas (da local ao internacional). Isso é interessante para mostrar como se dá a transformação do espaço por meio de intervenções cotidianas tanto da sociedade, em 
que o aluno está inserido, como dos outros órgãos, a fim de fazê-los refletir sobre o que significa estudar e ensinar a disciplina para os alunos atualmente.

A preocupação em caracterizar as competências e as habilidades a serem desenvolvidas nos elementos curriculares destaca a concepção da educação atual. Tantos os PCNs como outros planos de ensino vêm descrevendo a importância que os conteúdos devem ter para atingir os objetivos necessários à compreensão do aluno sobre determinado assunto. Podemos dizer que, pensar esses aspectos dentro da Geografia, permite ao professor organizar a aprendizagem e o saber para que, nos conteúdos, desenvolvam as habilidades específicas dentro da disciplina, já que ela envolve certas competências e habilidades. De uma forma geral, todos sabem que ler, analisar e interpretar são aspectos relevantes, mas fazer isso na Geografia representa saber ler, codificar, analisar os códigos desta disciplina (os mapas, gráficos, tabelas, os conceitos geográficos, dentre outros).

A concepção geográfica descrita nos elementos curriculares está relacionada à uma geografia Crítica, Humanística e Cultural, abarcando elementos conceituais que, nos currículos anteriores, não estavam descritos. O conceito de lugar aparece nesses currículos, o que permite a discussão de uma concepção cultural e humanística. O debate do espaço urbano e rural possibilita aos professores conduzir as aulas numa perspectiva de trabalhar os elementos cartográficos visando o estudo da Zona Leste e da Zona Sul de São Paulo, articulando o espaço vivido pelos alunos e a produção do espaço urbano e rural da cidade de São Paulo, bem como e a escala nacional e local com a perspectiva da inter-relação com a escola global, a partir do momento em que ele na prática realize esta articulação, pois no currículo isso não está "claro".

Outro aspecto importante é a questão da observação dos acontecimentos do mundo atual como o espaço, a paisagem e o território suas mudanças e permanências que apresentarão diferentes significados nesse contraditório mundo pós-guerra fria, onde o poder se torna multipolar, o mundo se reestrutura em blocos regionais, com a aceleração urbana nos países em desenvolvimento, as cidades tendo novas funções, as indústrias se descentralizando para outras cidades, criando e modificando outras paisagens. A utilização exarcebada da Natureza para criar produtos, objetos técnicos que são colocados em determinados espaços, causando a aceleração dos impactos ambientais. A conjuntura do capital financeiro que possibilita a criação de metrópoles 
centradas em serviços, modificando as paisagens locais e permitindo que outros objetos circulem nesse lugar.

A evolução dos meios de comunicação que permitem massificação cultural no cotidiano. Os símbolos e signos que organização o espaço, o turismo que se torna uma atividade econômica importante na cultura urbana dos países, permitindo a muitas cidades, organizarem seus espaços para atraírem turistas e remodelam as suas paisagens. A utilização das festas e outras atividades culturais que estruturam a vida cotidiana dessa sociedade, que se modifica, se reestrutura e diversifica suas atividades para viverem conforme o mundo globalizado. Essas e outras são as diversas formas de relacionar os acontecimentos aos conteúdos de Geografia.

Temos pontos a considerar nos elementos propostos pelos professores: ainda há uma preocupação na centralização dos conteúdos, do mesmo modo que o espaço vivido pelos alunos. Apesar de estarem descritos em alguns objetivos, notamos que há lacunas na organização dos conteúdos voltados para as questões da Zona Leste e da Zona Sul de São Paulo e de como as formas desses espaços interferem na produção dos próprios, o que significa entender o espaço urbano numa perspectiva local inter-relacionado às dimensões da escala regional, nacional para compreender o que aconteceu globalmente, ou seja, como as outras metrópoles se situam nessa conjuntura; compreender o meio físico na perspectiva de produção urbana e rural do lugar em que vive; a importância que os meios de transporte têm para essa população que mora longe do seu trabalho. Qual função urbana tem a Zona Leste e a zona Sul de São Paulo e como o aluno observa o seu entorno? Que tipo de atividades econômicas encontra nesses lugares?

Se quisermos pensar o espaço vivido ao produzido dos alunos, compreender o bairro em que vive e a sua região é importante chamar atenção para uma organização espacial, territorial, de sua própria paisagem, de seu lugar e de sua localização que está relacionada a alguns aspectos: a Zona Leste e a Zona Sul são produtos das contradições existentes na escala global que interferem na escala nacional a qual modifica as interrelações entre os Estados e os municípios que têm funções, atividades, culturas, populações, meio físico diferenciados um dos outros e que transforma as paisagens, as fronteiras, as culturas e os espaços que são produzidos por uma sociedade no sistema capitalista.

Outro ponto a questionar é em relação aos conteúdos. Apesar de terem sido descritos e explicitados os seus significados, cremos que haveria uma inter-relação da própria compreensão do professor sobre este e como a geografia escolar se utiliza 
desses conceitos para trabalhar o vivido dos alunos, ou seja, quando desejamos explicitar o conceito de território (aquele conceito de território-solo não explica mais a atualidade), no qual alguns autores conceituam o território-fluído, território-usado, território-enclave. Estas conceitualizações possibilitam que o aluno compreenda que o território é um espaço de relação de poder, isto quer dizer que, a Zona Leste de São Paulo se confronta territorialmente com outros lugares articulando relações de própria delimitação territorial, por isso também caracterizado por esse nome (também por questões localizacionais nos que envolve dentro dela essas relações de poder). Assim, como pensar a paisagem urbana da Zona Sul, observar e analisar os elementos que influem na mudança e na permanência desta, em que medida as heranças culturais, sociais e econômicas estão intrínsecas nesta, e porque ela se modifica ao longo do tempo?

Na observação e na análise dos outros currículos, isto também se torna evidente: a falta de articulação escrita entre os conceitos e os conteúdos produzidos e concebidos, para transpor o envolvimento do cotidiano dos alunos.

Os conceitos e os conteúdos elaborados permitem que o professor trabalhe "estratégias", "metodologias" que intervêm no processo de aprendizagem. Neste ponto, os professores, ao darem importância aos materiais curriculares que utilizarão nas aulas, mostram a influência no processo do ensino do aluno. Sendo este um elemento necessário ao debate dos elementos curriculares, acreditamos que o currículo é uma intervenção política, cultural e social de uma seletividade, mas também é uma trajetória, um percurso a seguir, assim como orientar a construção do conhecimento escolar. Então, os recursos pedagógicos fazem parte da relação dos professores em busca de mecanismos que interfiram coerentemente nessa aprendizagem. Esta intervenção permite-o utilizar elementos que sejam pertinentes ao desenvolvimento de atividades que auxiliam na compreensão do cotidiano. Desta forma, saber trabalhar com diversas linguagens na área Geografia como cinematográfica, musical, escrita, poética com o conhecimento metodológico, está intrínseco no aspecto curricular, na organização do conhecimento, em parte das matérias escolares, no planejamento das aulas dos professores.

Assim, achamos pertinente a exposição sobre a avaliação, um reflexo direto da Didática e Metodologia que o professor desenvolve na sala de aula a fim de possibilitálo articular a compreensão dos conteúdos pelos alunos. É por meio de uma avaliação concisa e estruturada que aparecem os erros e os problemas conceituais dos mesmos e a 
busca do professor em melhorar o ensino e a aprendizagem. A relação do que, quando, como ensinar, deve estar conectado com o processo de como avaliar e o que se deve avaliar, pois é um processo contínuo.

\subsection{A história do currículo de Geografia contribuindo para compreensão da produção atual: uma revisão do processo curricular}

Os elementos curriculares desenvolvidos pelos professores das duas escolas estaduais são frutos de séculos de história do pensamento curricular da Geografia escolar. Isto implica em dizer, que a utilização do espaço cotidiano do aluno, da reprodução e fragmentação da disciplina é um processo que vem sendo discutido há muito tempo, por isso, argumentamos que os professores produziram algo próprio, mas ao mesmo tempo, de um acúmulo teórico.

O currículo de Geografia foi estruturado e pensado no meio de disputas territoriais dos países europeus que se instituíram como Estado-Nação, para conhecer mais sobre o seu território e de outros países. Foi concebido no momento em que a escola estava se organizando em meados do século XVIII. A Geografia teve uma importância crucial, porque os seus conteúdos foram selecionados para garantir uma demanda do Estado e da classe hegemônica: possibilitar a ideologia do nacionalismopatriótico. $^{7}$

Sobre a institucionalização da Geografia Capel (1981) comenta que na França e na Alemanha, no século XIX, o ensino de Geografia era importante, principalmente depois que a Alemanha se apossou de alguns territórios franceses, por meio do estudo territorial. Na Alemanha, a Geografia no ensino primário e no ensino secundário era obrigatória e determinou a forma de pensar do território alemão. As idéias de Humboldt (Natureza) e Ritter (História e Natureza) ${ }^{8}$ possibilitaram mais elementos dentro da Geografia alemã e que permeou o sistema escolar.

\footnotetext{
"A presença da geografia foi importante em todos os níveis e centros de ensino. Nas escolas primárias se partia primeiro como ensino "a vista", em forma de conversação e logo como lições em classes superiores. $\mathrm{O}$ ensino se referia a "figura da Terra e seus movimentos, os principais

${ }^{7}$ Para uma discussão mais aprofundada sobre o tema leia A dissertação de mestrado Vlach, Vania Rubia Farias. Propósito do ensino de geografia: em questão, o nacionalismo patriótico. Dissertação (Mestrado) São Paulo: FFLCH - Departamento de Geografia, 1988.

8 Horacio Capel (1981) detalha a importância dos dois teóricos na construção do conhecimento geográfico.
} 
elementos da geografia, os pontos cardinais, os sistemas de montanhas, o curso dos rios, etc., assim como os ramos da indústria de cada país e o mecanismo de sua administração". As noções referentes à constituição da Terra, meteorologia ou distribuição das plantas se estudava nos cursos de ciências naturais ou físicas”. Capel (1981:91).

A Geografia física e matemática foi constituída pelos teóricos como necessária para a discussão do ensino na escola, com elas, os alunos estudavam o seu lugar e a parte física que constituía o globo terrestre como: os rios, os mares, as plantas... Era a maneira encontrada pelos alemães de buscar na disciplina o sentimento da unidade alemã e a análise de seu território-solo.

No ensino francês, em meados do século XIX, no primário e secundário, a geografia objetivava despertar no aluno a observação, uma vez que a premissa geográfica se estabelecia em descrição dos aspectos físicos. A disputa entre a Alemanha e a França pelo poder dos territórios europeus com a derrota da última, percebendo-se o avanço alemão do ensino e a pesquisa sobre a geografia. A educação francesa foi revista e a geografia nesse momento, estruturou-se por meio da observação, do uso de mapas, do estudo físico, político e econômico. Os alunos desenvolveriam habilidades relacionadas a noções de Geografia física, ao estudo da Terra e do território francês. Esse momento foi importante para a expansão da geografia na Universidade, pois a necessidade de professores aumentou.

A Geografia no currículo brasileiro, introduzido em 1850, foi estruturada com aspectos semelhantes ao modelo francês e os principais conteúdos relacionados ao conhecimento da cosmografia, da astronomia, dos estudos físicos dos países e de seu próprio país. $^{9}$

Os conteúdos ministrados, além dos estudos da geografia matemática e descritiva, tinham o objetivo de sistematizar as bases físicas do país, fazendo, conforme a Geografia Determinista, uma descrição do patrimônio natural com seus principais aspectos: clima, relevo, hidrografia e outros. Logo, a importância de contemplarmos o nosso território-solo.

A preocupação com os conteúdos geográficos e seu ensino vem de há muito tempo. Lacoste (1988) comenta sobre a importância de se mudar a forma de ensinar Geografia, uma disciplina "enfadonha”, desinteressante para os alunos, pois não visava

\footnotetext{
${ }^{9}$ Rocha (1996) faz uma análise dos currículos brasileiros por meio da criação do Colégio Pedro II e como ocorreram algumas políticas educacionais para a implementação e o desenvolvimento da Geografia enquanto disciplina escolar.
} 
a ser crítica, nem ser direcionada para a experiência de vida dos alunos; mas como um interesse do Estado e das classes hegemônicas para cultivar sua ideologia.

Moreira (1987) também discursa sobre a questão do ensino geográfico, preocupado com a síntese de conteúdos, o padrão $\mathrm{N}$ (Natureza), H (Homem), E (Economia), no qual eram fragmentados os conteúdos e não discutia-se, na verdade, o espaço geográfico. Os dois autores fazem uma ótima discussão acerca da ideologia camuflada nos conteúdos geográficos, demonstrando o caráter destes, e para quem interessava, como o espaço discutido é o das classes hegemônicas.

Os livros didáticos e os currículos iniciam os estudos geográficos pela Natureza ( $1^{\mathrm{a}}$ parte da relação homem-meio), seguida pelo estudo do homem ( $2^{\mathrm{a}}$ parte da relação homem-meio) que, entretanto, se divide em estudos da população e das ações humanas compreendidas (e reduzidas) como atividades econômicas. Por isto, esta dualidade se acentua e a Geografia passa a ser uma disciplina da síntese - Física e Humana que reproduz uma divisão clássica das concepções: determinista, possibilista, aplicada...

Analisando a divisão física do Brasil, percebemos a divisão: geologia - estrutura dos minerais; geomorfologia - forma de relevo brasileiro; clima - das regiões; vegetação - diversificada; e outros, apesar de uma melhor explicação a respeito de sua utilização, a forma de se ensinar é a mesma, como menciona Moreira:

"Aqui começa o desfile das gavetas, isto é, a sucessão dos cacos, ou capítulos, com que quebramos a unidade dialética da natureza em segmentos paralelos: "litoral", "geologia", "relevo", "clima", "rede fluvial", "vegetação", "solos e, ocasionalmente, "síntese dos domínios ecossistêmicos". " Moreira (1987: 108).

Lacoste (1988) questiona o ensino de Geografia e, conseqüentemente, seus conteúdos, que estavam coordenados com o real objetivo dessa disciplina para os Militares e Estado, mas como uma camuflação de uma realidade na qual os poderosos não queriam mostrar.

Ele argumenta que a Geografia escolar não se preocupava em criticar e analisar a realidade e, é evidente, que nesse bojo estava relacionada à questão do espaço vivido pelo aluno. Ele questiona a decoreba, o enciclopedismo que a disciplina se tornou e que na escola sempre se repetia. Conforme Lacoste: 
“... Essa forma socialmente dominante da geografia escolar e universitária, na medida em que ela enuncia uma nomenclatura e que inculca elementos de conhecimento enumerados sem ligação entre si (o relevo - o clima - a vegetação - a população...) tem o resultado não só de mascarar a trama política de tudo aquilo que se refere ao espaço, mas também de impor, implicitamente, que não é preciso senão memória”. Lacoste (1988: 32).

Ou como menciona Brabant (1998:19) “...o enciclopedismo contribuiu para a abstração crescente do discurso geográfico, ao mesmo tempo que alimenta o tédio das gerações de alunos que classificaram a geografia entre as matérias a memorizar”.

Sendo assim, conforme a história filosófica do pensamento geográfico, os teóricos da Geografia Determinista estabeleciam e proporcionavam à geografia "status" científico. O determinismo da relação das leis naturais e o estudo da Natureza por meio da geografia física possibilitaram o seu desenvolvimento nas concepções dos elementos naturais como o clima, a hidrografia, o relevo, que eram parte dos conteúdos prescritos nas aulas do primário e do secundário.

Os teóricos do Determinismo argumentavam por meio do pensamento filosófico alemão, tendo seu maior exemplo Frederich Ratzel que estabeleceu o território enquanto solo, ou seja, extensão, limites. Isto possibilitou aos professores de Geografia trabalharem em suas aulas as fronteiras e a perceberem a utilização dos recursos naturais. O conceito de território se torna um objeto importante para a ciência geográfica, uma vez que, ao estabelecer as diferentes possibilidades de se estudar uma localização terrestre, propicia aos geógrafos um conhecimento do domínio que o cercam.

O currículo brasileiro no período de sua primeira organização estava relacionado à Geografia descritiva e seus elementos eram o estudo da cosmografia que relacionava a operações físicas e cálculos matemáticos; o estudo do meio físico e todo um detalhamento: golfo, rios, bacias e outros conteúdos e a estruturação regional.

Lacoste (1988) analisa como a Geografia dos Professores, possibilitou que a disciplina fosse "usada" como estímulo ao sentido patriótico e sem o senso crítico para discutir o papel da disciplina na sociedade e no contexto escolar.

A Geografia, no cenário educativo brasileiro, no começo do século $\mathrm{XX}$, se consolidava como um saber sistematizado e que possibilitaria aos poucos legitimar uma ideologia patriótico-nacionalista. Naquela época não havia professores formados em 
Geografia, mas pessoas autodidatas que tinham vários conhecimentos. O cunho pedagógico no princípio não existia e, conseqüentemente, o que ocorria na escola era a reprodução de conteúdos.

Com o regresso do geógrafo Delgado de Carvalho, que estudou Geografia na França e permaneceu por um período neste país, na década de 1920, o seu ingresso no Colégio Pedro II, desenvolveu-se uma reestruturação na metodologia de ensino da disciplina, discutindo a importância de elementos relacionados à realidade do aluno e ao processo de aprendizagem do conhecimento geográfico.

Apesar do debate da observação no processo do ensino francês e das argumentações feitas por Delgado de Carvalho para a importância de uma geografia voltada para a realidade do aluno, o estudo da Geografia continuou descritivo e "decoreba", mantendo-se somente no cunho informativo, sendo que o ensino sobre a realidade vivida do aluno, e do seu espaço vivido não tinham nenhum suporte pedagógico para interligá-los.

Nos anos de 1930, a Geografia é muito valorizada. Com Getúlio Vargas no poder, cria-se uma "necessidade" pela exaltação do Brasil. A disciplina na escola passa a ser ministrada em todos os anos, há a criação da AGB (Associação de Geógrafos Brasileiro) em 1934, do IBGE (Instituto Brasileiro de Geografia e Estatística) em 1937 e do curso de Geografia e História na FFLCH-USP (Faculdade de Filosofia, Letras e Ciências Humanas) em 1934 e na Universidade do Distrito Federal (hoje UFRJ) em 1935. Estas mudanças trazem conseqüências, como a formação de professores licenciados em Geografia; o estudo das concepções geográficas brasileiras, apesar da ideologia francesa ser muito presente ${ }^{10}$ e a consolidação dos estudos geográficos financiados pelo Governo para conhecimento detalhado do seu território.

A incorporação da concepção Possibilista na França criou uma forma de embate ideológico com a determinista alemã, a possibilidade de pensar a disciplina num aspecto mais "humano", isto é, no qual a Natureza não agia e dominava a vida humana, mas que havia uma interação entre eles.

De certa forma, o embate fez com que houvesse uma divisão entre a natureza e a história e, conseqüentemente, entre as ciências naturais (Geografia Física) e as ciências humanas (Geografia Humana). A ciência geográfica trataria diferenciadamente os dois e o uso do método também seria diferenciado. A disciplina se caracteriza como uma

\footnotetext{
${ }^{10}$ Nos primeiros cursos de licenciatura de Geografia no Brasil na FFLCH - USP em 1934, os professores eram franceses.
} 
ciência nomotética (na qual se preocuparia pelo constante e permanente e tratariam de desvendar leis da natureza) e ao mesmo tempo, uma ciência idiográfica (na qual se preocuparia pelo único ou singular, pelos fatos ou acontecimentos, pelas condições circunstanciais no tempo e no espaço).

Nessa discussão culminou a dicotomia entre físico e humano, gerado pela característica metodológica e conceitual diferenciados. De acordo com os geógrafos, a Física apresenta termos de análises ligados aos elementos e leis naturais que seriam diferentes à Humana. Esses estariam relacionados aos fatos e acontecimentos da transformação da sociedade e sua inter-relação com o espaço vivenciado.

A separação entre o físico e o humano seria, para eles, inevitável para a discussão que culminou as diferentes percepções e concepções desses dois elementos. Por isso, a descrição do meio físico é decorrente das leis naturais, os processos ocorreriam independentes da ação humana: terremoto, rocha, relevo. Já, a inserção dos aspectos humanos se relacionam as questões política, social, cultural e econômica num contexto social. A discussão dicotômica é transportada para o ensino de geografia e permeia até hoje esse embate ideológico e metodológico.

Nesta perspectiva o francês Paul Vidal de La Blache, no começo do século XX, conforme Andrade (1986) comentava que a relação entre o homem e a natureza era complexa. A natureza foi considerada como fornecedora de possibilidades para que o homem interagisse com a paisagem. La Blache redefine o conceito "gênero de vida" que significa as possibilidades de o homem, por meio de técnicas, e da cultura, utilizar os recursos naturais modificando e vivendo de acordo com a estrutura local um modo de vida próprio.

O homem começa a estabelecer um papel de destaque nas concepções geográficas, não mais como um ser passivo, mas um ser ativo na análise e na transformação espacial. E nessas relações escolares também aparece o homem interagindo com a natureza (O Homem e o Meio, o Homem e o Clima). Essa relação poderia aproximar a discussão da realidade, a partir do momento em que, ao se tratar do homem e de suas interações com a sociedade e com o meio físico, de certa maneira, se poderia explicar o ser (o aluno agente e sujeito dessa transformação), mas se explica o Homem por intermédio do estudo da População.

Nesta perspectiva os conceitos geográficos que fomentavam o universo escolar eram a paisagem, a região e o território. Este último conceito ainda era conceituado como fronteira, limite que se estabelece em um determinado lugar. A paisagem como 
um elemento essencial, porque se evidenciava com o que vemos, com o que se modifica e fica visível no espaço. A paisagem seria a síntese das mudanças ocorridas em uma determinada região (que também se torna uma categoria importante). A paisagem natural e suas diversas formas, a paisagem transformada pelo homem. As regiões se traduziam num tipo de paisagem. Capel enfatiza (1981:343) a sua importância dizendo que: "A insistência na paisagem permitia identificar um objeto específico para a ciência geográfica, diferenciada claramente da ecologia e das diferentes disciplinas que contribuem também ao estudo da superfície terrestre".

Ao mesmo tempo, a região também é um elemento para a ciência geográfica porque os estudos regionais se tornam mais interessantes para a compreensão dos processos que são constituídos e materializados em um determinado lugar. Conforme Corrêa (1990) a região é a expressão espacial da ocorrência de uma mesma paisagem geográfica. O objeto da Geografia Possibilista é portanto, a região, e a geografia, confunde-se então, com a geografia regional.

$\mathrm{Na}$ universidade, as monografias regionais cresceram consideravelmente, e a geografia escolar abarca essa concepção trabalhando com as regiões brasileiras, cada uma de acordo com a história do pensamento correspondente.

Segundo Capel (1981:321), Hettner caracteriza o que seria a Geografia: "A geografia trataria, em troca, das diferentes localizações na superfície terrestre e descreveria unidades espaciais, definindo-as e comparando-as entre si”. Chamamos a atenção para o fato de a geografia escolar desenvolver os conteúdos por diferenças regionais e por comparações. Primeiro definindo os aspectos físicos, e depois caracterizando as áreas da superfície.

Ao mesmo tempo, o Método Regional se oporia ao Determinismo e ao Possibilismo, porque iria se preocupar em estudar os diversos aspectos das partes da Terra, não só pela relação entre o homem e a natureza, mas sim de uma integração dos fenômenos em uma parte da superfície terrestre, preocupando-se com a diferenciação das regiões como objeto de estudo da Geografia.

A discussão sobre a região se baseava nas conexões de "áreas" comuns estabelecendo uma forma de pensar e estruturar o espaço, o conjunto de fatores de uma característica proveniente na configuração regional. A construção do conceito de Região como conjunto de característica de uma determinada área se torna importante para os geógrafos classificarem e utilizarem dessa nova concepção. Esta foi de grande benefício para o Governo de Getúlio Vargas, pois com o método regional, ele pôde traçar o 
planejamento do uso dos recursos e investimentos para determinadas áreas do território brasileiro e usufruir também de seus benefícios. Além disso, o crescimento populacional e econômico do país permitia ao Governo analisar, estruturar e construir uma imagem de nação brasileira.

Nesse momento, a Geografia escolar no contexto das reformas educativas brasileiras teve um papel importante na organização e na construção de uma imagem de nação construída e mantida para valorizar o estudo do território nacional. A disciplina foi utilizada como instrumento ideológico para territorializar, patriar um povo e a importância de seu governante sendo considerado "o pai da nação brasileira". A disciplina mascarava os interesses dos "maiores" em explorar os recursos naturais do nosso extenso e vasto território.

A inserção do conhecimento geográfico nas instituições públicas colaborou para a discussão dos fenômenos espaciais e a sua importância na configuração territorial e dos recursos facilitando o estudo e o investimento na imagem de um país com grandes proporções físicas, territoriais e populacionais. A integração territorial da nação seria o ponto determinante para o incentivo do ensino de geografia ser mais efetivo, devido à massificação do ensino educativo e da organização sistêmica das disciplinas.

O estudo de nosso território nacional (enquanto solo-extenso na concepção determinista ratzeliana), o estudo das riquezas brasileiras: ouro, o ferro...; o estudo das belezas naturais e da Natureza, como vegetação, o litoral exuberante, os rios, os lagos, as formas de relevo, do clima e outros. O estudo da população brasileira, sua economia. Moreira (1987) critica essa forma de organização dos conteúdos em forma de gavetas como se fosse uma compartimentação de informações, em que cada momento, ao retirála, o aluno aprende sobre um tópico, se nutre de informações, depois arquiva e abre novamente outro compartimento. Essa maneira facilitava a arrumação dos conteúdos e das aulas, pois era somente memorizar as informações solicitadas. Durante muito tempo o currículo de Geografia foi apresentado com essa estruturação.

Os conteúdos também eram organizados por meio da discussão do método regional: observa-se a primeira criação das áreas regionais na qual o determinismo era a base da concepção por meio das regiões naturais. Desta forma, o conceito de região perpassa a escola para analisar como cada característica natural própria e como cada grupo regional se adequava e vivia nela.

A criação do IBGE em 1937 foi decisiva e ajudou a Geografia a ter "status" e a aumentar sua importância no desenvolvimento e pensamento ideológico escolar. Nessa 
instituição todos os dados sobre o país eram tabelados e analisados por aspectos econômicos até os aspectos naturais do nosso território, sendo a metodologia regional desenvolvida pelos trabalhos dos geógrafos.

Na década de 50, surge a Nova Geografia - A Geografia Teorético-Quantitativa, corrente que se destacava por usar em larga escala os modelos matemático-estatísticos. Originalmente, estudado na Suécia, EUA e Grã-Bretanha, foram os estadunidenses que conseguiram propagar as idéias de quantificar todas as coisas inclusas no espaço como forma de manipular e desenvolver as áreas com determinados potenciais para as indústrias, o comércio, ou seja, a prática da natureza econômica e exploração dos recursos. Contrapondo-se ao determinismo, ao possibilismo e ao método regional afirma Corrêa:

"Ao contrário do paradigma possibilista ou da Geografia hartshoriana, a nova procura leis ou regularidades empíricas sob a forma de padrões espaciais. $\mathrm{O}$ emprego de técnicas estatísticas, dotadas de maior ou menor grau de sofisticação... É conhecida também como geografia teorética ou geografia quantitativa" Corrêa (1990: 18).

A concepção possibilitou para a estruturação de novos espaços, o desenvolvimento dos planejamentos, em conseqüência da Segunda Guerra Mundial que devastou muitos países. Estes se reestruturariam para se organizar e utilizar seus recursos (como caso do Brasil). O conceito de espaço passa a ser o foco do objeto da Geografia. Como destaca Capel (1981: 388-389):

“A preocupação pela geometria, pelo que Harvey chamou 'a linguagem da forma espacial', está intimamente relacionada com a ênfase que agora se põe o espaço. Nos encontramos aqui com outra das características importante na nova geografia. A localização espacial da população e das atividades se convertem no tema destacada da investigação. O espaço terrestre, a organização espacial, as distribuições e associações espaciais, as estruturas espaciais, as regularidades no espaço são questões que passam agora em primeiro lugar nas preocupações dos geógrafos, até o ponto de podermos perguntar se tem aparecido de fato uma nova formulação do problema chave da geografia."

No currículo na década de 70, devido ao método quantitativo, os conteúdos apresentavam a utilização de tabelas e gráficos que se tornaram relevantes à análise matemática e ao planejamento a ser executado pelo Governo. A construção do 
pensamento matemático, principalmente após a Segunda Guerra Mundial, possibilitou a revisão do método regional natural e passou a estabelecer nas regiões planejadas a distribuição de renda e de recursos por áreas. A Geografia escolar agrega essa concepção e reproduz estes estudos no qual cada região foi dividida de acordo com suas características econômicas e aspectos físicos. No caso do Brasil, produziu-se a divisão do IBGE em regiões Norte, Sudeste, Sul, Centro-Oeste e Nordeste, que também tinha muitas características da Geografia Possibilista.

Ainda, segundo Andrade (1986) no Brasil, a Geografia teórico-quantitativa foi utilizada pelo Governo Militar para consolidar e integrar a economia brasileira como dependente a uma economia mundial, o que ajudou a propagar o país como próxima potência mundial, sendo que a ajuda do IBGE foi decisiva com o fornecimento de todos os dados sobre o país.

A Geografia escolar brasileira também consolida em seus conteúdos essas idéias: representação de gráficos, tabelas, informações sobre a economia para caracterizar os avanços da economia brasileira perante o mundo.

Nessa mesma década, um paradigma permeava a Geografia com o rompimento das outras correntes, no caso, do marxismo na teoria da geografia. A Geografia Crítica - no qual defendem os geógrafos marxistas levam em consideração que a sociedade tem uma história, portanto, ela faz parte desse processo contraditório que se tornou o mundo. A inserção do cotidiano mostra claramente a importância de examinar que cada um de nós faz parte dessa espacialidade, dessa transformação do mundo.

A produção de mercadoria distingue-se no modo produtivo em duas categorias de trabalho importantes: a burguesia e o proletariado. Essa relação contraditória produz concepções especiais em sua forma, função e estrutura. Perceber o espaço é compreender as relações dialéticas na sociedade por meio do processo produtivo, propicia uma forma de pensá-lo e organizá-lo e, conseqüentemente, a realidade vivida. A necessidade dessa organização é refletida na produção e construção de objetos que se materializam e territorialização para o uso da sociedade.

O conceito de espaço se torna o elemento chave para a Geografia denominada Crítica porque explica como a sociedade agora se organiza e, espaço geográfico é também transformação dos processos decorrentes do modo de produção dela. O homem não é um espectador, mas aquele que produz e reproduz ao longo de sua existência o espaço através das contradições, das transformações sociais. Assim, como diz Moraes 
(1988: 15): “o espaço produzido é um resultado da ação humana sobre a superfície terrestre que expressa cada momento, as relações sociais que lhe deram origem”.

Os conceitos de espaço, de território, de paisagem, de região e de lugar são apresentados como elementos chaves da Geografia e com novos parâmetros para estudar a disciplina ${ }^{11}$. Para entender as relações numa visão marxista, os conceitos estão associados a uma reflexão sobre o processo ideológico no qual vincula-se o marxismo. Em meados do ano 1980, a geografia escolar agrega as discussões econômicas nos seus conteúdos, isso é observado nos livros ${ }^{12}$ ao retratarem os conteúdos voltados para a concepção do trabalho, do sistema capitalista e socialista e a associação da disputa entre classes.

A sociedade modifica e produz o espaço, e no ensino, o ser humano se manifesta como o transformador e consumidor da natureza pela necessidade de desenvolver e consumir algo para viver e como forma de manifestar seu hábito cultural. Na percepção determinista, o homem era dominado pela natureza; na possibilista ele convivia com o meio, e no marxismo, o homem controla a natureza para dela usufruir.

Quase que no mesmo momento, há outra corrente que se interpõe à Geografia Crítica: a Geografia Humanística que discute o espaço vivido das pessoas por meio da fenomenologia, hermenêutica e outras formas. O homem se organiza no espaço de forma afetiva. Buttimer (1982), Yi Fi-Tuan (1982) afirmam que a Geografia Humanística organiza o espaço por meio de uma visão fenomênica, ou seja, das coisas que estão expressas a sua volta, de um simbolismo. O lugar, dentro da visão humanística, é uma categoria junto ao espaço, importante aspecto para a compreensão desse universo complexo, que é viver.

Concomitantemente a esta discussão existe a questão cultural, forma expressiva da mudança dos povos e conseqüentemente, do espaço e da paisagem. A Geografia Cultural exprime as transformações da cultura na paisagem como sua história e suas características interfeririam no espaço que está a sua volta. No currículo escolar, se adentrou este conceito ao estabelecer e estudar as relações culturais entre os povos, e retomou o conceito de paisagem cultural na Geografia.

\footnotetext{
${ }^{11}$ Santos (1978) em seu livro Por uma nova Geografia detalha como ocorreu esse processo de mudança dentro da Geografia. Como o nosso foco é fazer um panorama geral das categorias e conteúdos e sua importância na escola, não nos aprofundaremos nessas questões.

${ }^{12}$ Ler a dissertação PEREIRA, D. A. C. Origem e consolidação da tradição didática na Geografia escolar brasileira. SP-USP, 1989. no qual relata como o livro didático aparece os conceitos provenientes da Geografia Crítica.
} 
A idéia é permitir que o indivíduo compreenda as relações das diferentes culturas relacionadas aos diferentes tipos de lugares e territórios estabelecendo relações únicas com estes. A cultura se torna uma fonte de manifestações do cotidiano e se materializam em uma determinada paisagem. O processo cultural de um povo é a marca de uma herança e de uma identidade. A questão do negro, do asiático, do branco, do indígena, do italiano, do latino... deve ser entendida também pela organização cultural desses grupos e como transformam o espaço em que vivem.

Na Geografia Crítica, na Geografia Cultural e na Geografia Humanística começamos a perceber que os geógrafos incorporam a realidade vivida pelo aluno, ao analisar como ele faz parte dessa discussão, como ele se insere nessa sociedade contraditória.

Ao mesmo tempo, a Geografia Humanística retoma a relação do ser com o espaço que o envolve no lugar de pertencimento, no qual sua relação se torna viva e no qual ele presencia. A vida humana é posta em questão, analisando como o homem percebe esse espaço. Essa Geografia se torna mais perceptiva para os alunos.

Na Geografia Cultural, o espaço é caracterizado pelos povos e suas culturas e a paisagem é a expressão de marcos históricos e mudanças geográficas que cada um exprime. A cultura se manifesta em diferentes lugares e espaços diferenciadamente, por meio das heranças de suas gerações que transformaram a maneira da organização espacial. A evidência é nítida ao falar-se, por exemplo, da cidade de Blumenau (Santa Catarina), sua arquitetura está relacionada à cultura alemã, da mesma maneira quando se menciona a cidade de Bento Gonçalves (Rio Grande do Sul) com arquitetura italiana.

Analisar a história nos possibilita questionar o como e o porquê a estruturação dos currículos de Geografia e quais foram suas finalidades. A compreensão da concepção de cada corrente do pensamento geográfico e da geografia escolar percebese, na relação dos conceitos aos conteúdos da escola em dado momento dessa história. O ensino de Geografia era, então, caracterizado e delimitado de acordo com os interesses de Governo e os conteúdos eram estanques da realidade e de qualquer crítica relacionado a ele.

As reformulações dos currículos são analisadas conforme o contexto de cada época, com o espaço vivido e produzido pela sociedade capitalista, que nos permite organizar e formular conteúdos e conceitos mediante a percepção dos professores sobre o que seja importante para o aprendizado de seu aluno. 
A Geografia Escolar possibilita aos alunos um pensamento crítico, buscando a construção da cidadania, do pensar seu lugar, seu espaço nacional e seu espaço mundial e pensar a relação da luta entre classes. As concepções geográficas foram elementos no processo de formação docente, porque estas caracterizaram os diferentes olhares sobre a produção em cada contexto histórico e sua análise geográfica. Elas nos permitiram analisar a importância de pensar que tipo de professor seja ideal e qual sua importância no processo de transformação dentro e fora da escola.

A formação do professor de Geografia está vinculada a um processo ideológico e seletivo de cada conceito geográfico e que possibilitou o docente a produzir e reproduzir na escola uma parte dessa concepção.

Considerando as afirmações de Lacoste (1988) a Geografia dos Professores tinha elementos diferenciados da Geografia dita "dos Estados Maiores"; numa “organização enciclopedista", em que os professores produziam no ambiente escolar uma geografia relacionada à descrição da natureza sem conexão com os acontecimentos atuais e a descrição do agir humano, sem uma análise da vivência.

A linha de pensamento dicotômica e antagônica entre a parte humana e a parte física estava muito presente e a análise dos contextos não eram realizados. Concordamos com ele neste sentido, porque ainda temos professores que desassociam a análise e a compreensão dos fenômenos do cotidiano realizando uma geografia "memorística".

Por outro lado, os estudos ligados à Geografia Crítica, Humanística e Cultural dentro da universidade reorganizaram a lógica do pensamento geográfico e a formação de professores com estudos mais críticos ou com outras possibilidades metodológicas e a produção de pesquisas voltadas para a área do ensino de Geografia.

Para mostrar a estruturação dos currículos de Geografia procuramos fazer um recorte apresentado pelo Colégio Pedro II $^{13}$ que durante muito tempo foi a escola oficial do Império e depois da República e nos possibilita analisar como se organizava os

13 O Colégio D. Pedro II está situado no Rio de Janeiro, é uma instituição pública de ensino. Primeiramente chamado de Seminário dos Órfãos de São Pedro, criado em 1739. Depois com o decreto de 02/12/1837, data do aniversário do Imperador D. Pedro II, foi reformado, transformando-se em instituto de ensino secundário, com o título de Colégio D. Pedro II. AZEVEDO, F. apud COLESANTI, M. T. M. O ensino da Geografia através do livro didático no período de 1890 a 1971 . Rio Claro - SP, 1984 Dissertação de Mestrado em Geografia. UNESP, p. 9. O intuito de escolhermos este colégio foi pelo fato de ser a primeira instituição com o currículo de Geografia e pesquisamos a continuidade dos currículo desde 1850 até 1990. 
conteúdos da disciplina em épocas distintas: 1850, 1898, 1931, 1951, 1982, 1990. Não temos o intuito de aprofundar sobre os currículos, mas mostrar e analisar como as concepções se vinculam teoricamente e se agregam ao longo do tempo, as correntes permanecem na Geografia escolar até nos dias atuais.

\section{MEC- Colégio Pedro II \\ Secretaria de Ensino \\ Plano de Curso \\ Disciplina: Geografia \\ Ano: 1990/1991/1992}

\section{Série: $\mathbf{5}^{\mathbf{a}}$ \\ Carga horária: 71 horas + 19 horas destinadas à revisão, à verificação e a provas (total: 90 horas)}

Objetivo Geral da disciplina: Compreender a dinâmica do espaço geográfico, entendendo-o como produto da relação entre a natureza e o homem socialmente organizado; compreender os processos através dos quais os elementos naturais interagem, privilegiando uma abordagem de integração ambiental; relacionar as principais características das atividades econômicas com a organização do espaço geográfico.

\begin{tabular}{|c|c|}
\hline CONTEÚDO PROGRAMADO & OBJETIVOS ESPECÍFICOS \\
\hline 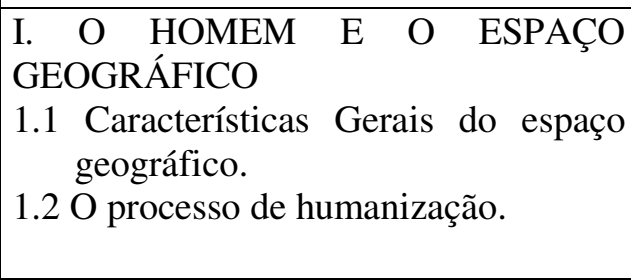 & $\begin{array}{l}\text { - Compreender o caráter dinâmico do espaço } \\
\text { terrestre, bem como a participação do homem, } \\
\text { organizado em sociedade, na sua transformação; } \\
\text { - Dominar os seguintes aspectos geográficos: } \\
\text { paisagem natural/paisagem humana; espaço } \\
\text { geográfico; humanização do espaço. }\end{array}$ \\
\hline $\begin{array}{l}\text { II. O HOMEM E SUA RELAÇÃO } \\
\text { COM A NATUREZA } \\
\text { 2.1 O homem e o trabalho. } \\
\text { 2.2 As atividades extrativas. } \\
\text { 2.3 Os recursos naturais. }\end{array}$ & $\begin{array}{l}\text { - Reconhecer o trabalho como atividade que } \\
\text { relaciona homem e natureza; } \\
\text { - Reconhecer que esta relação varia historicamente } \\
\text { e culturalmente; } \\
\text { - Compreender as atividades extrativas como as } \\
\text { formas mais elementares de relacionamento } \\
\text { econômico homem-natureza; } \\
\text { - Compreender as possibilidades e limites da } \\
\text { utilização dos recursos naturais; } \\
\text { Dominar os seguintes aspectos geográficos: } \\
\text { trabalho, cultura, extrativismo, recurso natural. }\end{array}$ \\
\hline
\end{tabular}




\begin{tabular}{|c|c|}
\hline $\begin{array}{l}\text { III. } \\
\text { LOCALIZAÇÃO NO NO ESPAÇO } \\
\text { TERRESTRE } \\
\text { 3.1 A terra no sistema solar: estações } \\
\text { do ano. } \\
\text { 3.2 Orientação na superfície terrestre. } \\
\text { 3.3 As formas de representação do } \\
\text { espaço terrestre: Trabalho com mapas }\end{array}$ & $\begin{array}{l}\text { - Compreender a posição da terra no espaço, } \\
\text { objetivando identificar as formas de orientação } \\
\text { sobre a superfície terrestre e a existência de } \\
\text { diferentes estações do ano; } \\
\text { - Reconhecer o Globo e o Mapa como } \\
\text { representação simplificada e reduzida do real; } \\
\text { - } \text { Identificar, no mapa, quais os elementos } \\
\text { representados correspondem a realidade naturais, } \\
\text { históricos ou a convenções cartográficos; } \\
\text { - Realizar operações simples de escalas; } \\
\text { - Dominar os seguintes aspectos geográficos: } \\
\text { estações do ano, pontos cardeais/colaterais, } \\
\text { convenções cartográficas, linhas imaginárias } \\
\text { (principais paralelos), zonas climáticas e escala } \\
\text { gráfica. }\end{array}$ \\
\hline $\begin{array}{l}\text { IV A NATUREZA E A FORMAÇÃO } \\
\text { DA SUPEFÍCIE TERRESTRE } \\
\text { 4.1 O processo de formação da crosta } \\
\text { terrestre. } \\
\text { 4.2 A formação da hidrosfera. } \\
\text { 4.3 As formas do relevo terrestre. } \\
\text { 4.4 Os processos de modificação do } \\
\text { relevo. }\end{array}$ & 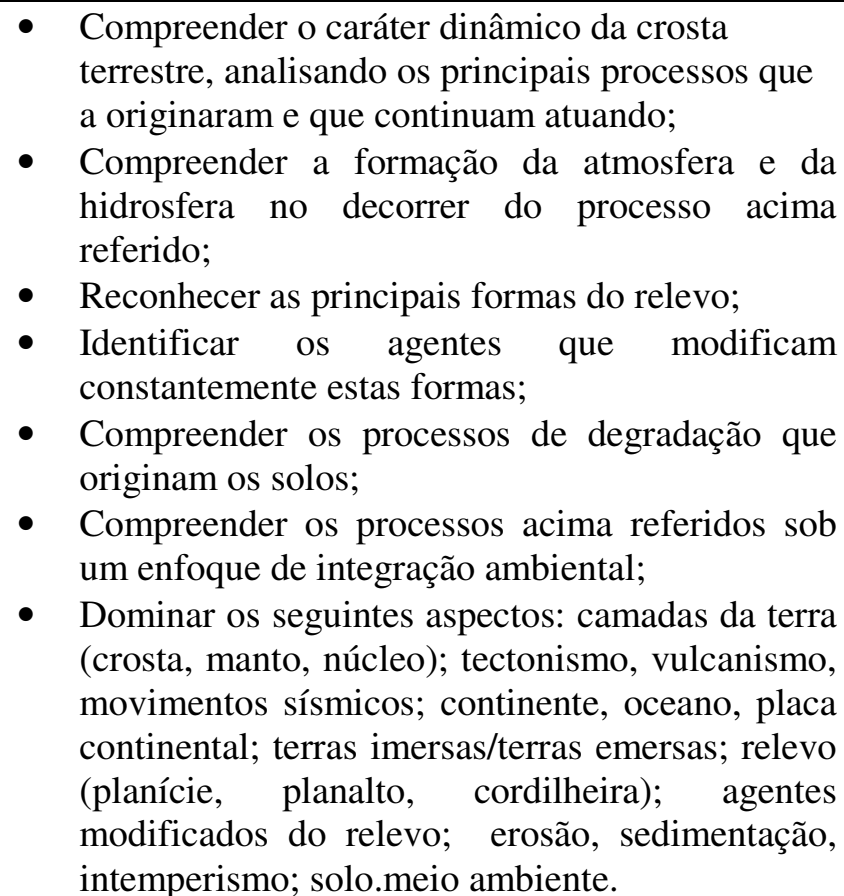 \\
\hline $\begin{array}{l}\text { V O HOMEM E A ORGANIZAÇÃO } \\
\text { DO ESPAÇO TERRESTRE. } \\
\text { 5.1 A transição do extrativismo para a } \\
\text { agricultura e a criação. } \\
\text { 5.2 A importância da agricultura e a } \\
\text { criação. } \\
\text { 5.3 Os sistemas agrícolas e de criação. } \\
\text { 5.4 A agricultura e sua relação com a } \\
\text { organização do espaço e com as demais } \\
\text { atividades econômicas. }\end{array}$ & $\begin{array}{l}\text { - Compreender o alto grau de integração das } \\
\text { atividades agro-pecuárias ao restante da } \\
\text { economia nas sociedades modernas; } \\
\text { - Compreender a importância da agricultura para o } \\
\text { surgimento da cidade e para a sociedade urbana } \\
\text { das atualidade; } \\
\text { - Dominar os seguintes aspectos geográficos: } \\
\text { agricultura/pecuária; sistemas agrícolas e de } \\
\text { criação (intensivo e extensivo); técnicas } \\
\text { agrícolas (monocultura, policultura, rotação de } \\
\text { culturas...); agroindústria. }\end{array}$ \\
\hline
\end{tabular}

Série: $6^{\mathbf{a}}$

Carga horária: 72 horas +18 horas destinadas à revisão, à verificação e a provas (total: 90 horas) 
Objetivo Geral da disciplina: Compreender a dinâmica do espaço geográfico, entendendo-o como produto da relação entre a natureza e o homem socialmente organizado; examinar os processos através dos quais os elementos naturais interagem, privilegiando uma abordagem de integração ambiental e relacionar as principais características das atividades econômicas com a organização do espaço geográfico.

\begin{tabular}{|c|c|}
\hline CONTEÚDO PROGRAMADO & OBJETIVOS ESPECÍFICOS \\
\hline $\begin{array}{l}\text { I. A ORGANIZAÇÃO DO ESPAÇO } \\
\text { INDUSTRIAL } \\
\text { 1.1 O surgimento da } \\
\text { atividade industrial. } \\
\text { 1.2 A distribuição da } \\
\text { atividade industrial no espaço. } \\
\text { 1.3 A indústria e as demais atividades } \\
\text { econômicas. } \\
\text { 1.4 A circulação de mercadorias }\end{array}$ & $\begin{array}{l}\text { - Compreender as características gerais da } \\
\text { produção de bens na sociedade atual, } \\
\text { comparando com as formas pré-industriais de } \\
\text { produção; } \\
\text { - Compreender o marco representado por esta } \\
\text { atividade na história da sociedade humana, } \\
\text { salientando seu papel no surgimento de uma } \\
\text { nova forma de organização espacial e social; } \\
\text { - Apontar os principais determinantes da } \\
\text { atividade industrial, correlacionando-os com a } \\
\text { atividade agrícola e com a mineração; } \\
\text { - Identificar fatores de localização industrial; } \\
\text { - Compreender a importância da circulação de } \\
\text { mercadorias para a atividade industrial; } \\
\text { - Dominar os seguintes aspectos geográficos: } \\
\text { artesanato/indústria moderna; revolução } \\
\text { industrial/capitalismo; mercadoria/mercado } \\
\text { consumidor; divisão do trabalho; mineração; } \\
\text { matéria-prima; fonte de energia; meios de } \\
\text { transportes. }\end{array}$ \\
\hline $\begin{array}{l}\text { II. O ESPAÇO URBANO } \\
\text { 2.1 O surgimento da cidade. } \\
\text { 2.2 A relação campo/cidade. } \\
\text { 2.3 O espaço intra-urbano. }\end{array}$ & $\begin{array}{l}\text { - Compreender a relação entre a atividade } \\
\text { industrial e o crescimento das cidades; } \\
\text { - Identificar as funções urbanas; } \\
\text { - Compreender a formação do espaço urbano } \\
\text { como um processo histórico, remetendo no } \\
\text { exemplo na cidade/bairro do aluno; } \\
\text { - Compreender as atividades características da } \\
\text { cidade, destacando sua importância para toda a } \\
\text { sociedade; } \\
\text { Dominar os conceitos: urbanização, funções } \\
\text { urbanas, comércio, transporte/transporte } \\
\text { coletivo; serviços públicos. }\end{array}$ \\
\hline
\end{tabular}




\begin{tabular}{|c|c|}
\hline $\begin{array}{l}\text { III. A POPULAÇÃO } \\
\text { 3.1 A estrutura populacional. } \\
\text { 3.2 O crescimento da população. } \\
\text { 3.3 A distribuição da população e seus } \\
\text { movimentos. }\end{array}$ & 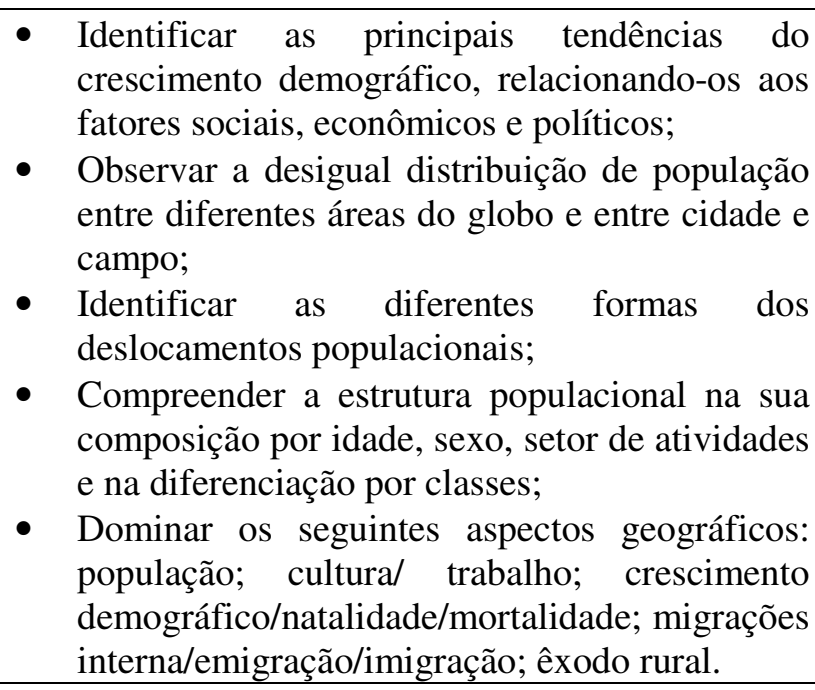 \\
\hline $\begin{array}{l}\text { IV. (INSTRUMENTAL) } \\
\text { LOCALIZAÇÃO NO ESPAÇO } \\
\text { TERRESTRE. } \\
4.1 \text { O mapa como forma de } \\
\text { representação do espaço terrestre }\end{array}$ & 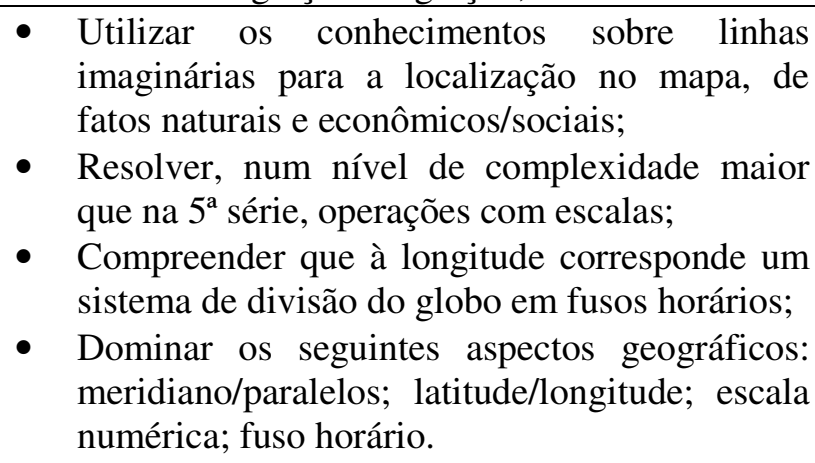 \\
\hline $\begin{array}{l}\text { V. AS PAISAGENS NATURAIS, A } \\
\text { BIOSFERA E O HOMEM. } \\
\text { 5.1 Os materiais componentes da } \\
\text { crosta. } \\
\text { 5.2.Os oceanos } \\
\text { 5.3 As águas continentais } \\
\text { 5.4 A dinâmica atmosférica } \\
\text { 5.5 As paisagens vegetais } \\
\text { 5.6 O homem e o equilíbrio ecológico. }\end{array}$ & $\begin{array}{l}\text { - Identificar os materiais componentes das } \\
\text { rochas destacando sua utilização econômica; } \\
\text { - Identificar as principais características da } \\
\text { porção marítima da hidrosfera, ressaltando sua } \\
\text { importância para o homem; } \\
\text { - Compreender a dinâmica das águas } \\
\text { continentais, destacando os elementos } \\
\text { componentes das bacias hidrográficas e seu } \\
\text { aproveitamento econômico; } \\
\text { - Compreender os elementos fundamentais da } \\
\text { dinâmica atmosférica; } \\
\text { - Caracterizar as principais paisagens vegetais, } \\
\text { correlacionando-as com os tipos climáticos; } \\
\text { - Constatar um ou mais casos de desequilíbrio } \\
\text { ecológico induzido pelo homem, envolvendo os } \\
\text { diversos elementos referidos nos objetivos } \\
\text { anteriores e destacando seu caráter integrado; } \\
\text { - Compreender a responsabilidade do homem e } \\
\text { com relação ao meio-ambiente; } \\
\text { Dominar os seguintes aspectos geográficos: } \\
\text { rochas, movimentos das águas oceânicas; bacia } \\
\text { hidrográfica; clima e elementos constituintes; } \\
\text { paisagens vegetais e ecossistemas. }\end{array}$ \\
\hline
\end{tabular}


Série: $7^{\mathrm{a}}$

Carga horária: 72 horas +18 horas destinadas à revisão, à verificação e a provas (total: 90 horas)

Objetivo Geral da disciplina: Compreender o mundo como um todo e sua dinâmica, entendendo que seu estudo em partes tem apenas um caráter de instrumental didático; compreender o espaço enquanto expressão material visível resultante da ação de forças que o engendram, tanto a nível local quanto a nível mundial; identificar e compreender as desigualdades econômicas, sociais e políticas existentes no mundo como produtos históricos refletidos na organização espacial e, portanto, sem caráter de imutabilidade; entender que o estudo do mundo com suas partes diferenciadas contribuem não só para a compreensão da realidade mundial, como também para a conscientização de sua própria realidade.

\begin{tabular}{|c|c|}
\hline CONTEÚDO PROGRAMADO & OBJETIVOS ESPECÍFICOS \\
\hline $\begin{array}{l}\text { I. PANORAMA DO MUNDO } \\
\text { ATUAL } \\
\text { 1.1 O Planisfério. } \\
\text { 1.2 Antecedentes históricos } \\
\text { 1.3 Contexto social, político } \\
\text { e econômico } \\
\text { 1.4 O capitalismo e o } \\
\text { socialismo características básicas }\end{array}$ & $\begin{array}{l}\text { - Abordar o estudo das áreas geoeconômicos do } \\
\text { mundo contemporâneo através do processo } \\
\text { histórico, identificando os fatores responsáveis } \\
\text { pela atual conjuntura sócio-econômica } \\
\text { mundial; } \\
\text { - Apreender as seguintes noções fundamentais ao } \\
\text { entendimento do conteúdo básico proposto: } \\
\text { Revolução industrial, capitalismo, DIT, } \\
\text { imperialismo, economia de dependência, } \\
\text { socialismo, Terceiro mundo. }\end{array}$ \\
\hline $\begin{array}{l}\text { II. EUROPA } \\
\text { 2.1 Antecedentes históricos } \\
\text { 2.2 A natureza e a organização do } \\
\text { espaço. } \\
\text { 2.3 As diferentes paisagens naturais - } \\
\text { relação Norte/Sul. } \\
\text { 2.4 A Comunidade Econômica } \\
\text { Européia e a situação sócio- } \\
\text { econômica dos países membros. } \\
\text { 2.5 O COMECON: situação } \\
\text { econômica e as inter-relações entre } \\
\text { os países membros. }\end{array}$ & $\begin{array}{l}\text { - Identificar o espaço europeu em suas } \\
\text { características físicas enquanto território que } \\
\text { condicionou o desenvolvimento do processo } \\
\text { histórico de formação dos Estados Nacionais } \\
\text { no Continente; } \\
\text { - Diferenciar a formação e importância das } \\
\text { organizações econômicas e identificar os } \\
\text { fatores que promoveram a unificação } \\
\text { econômica e política no Continente; } \\
\text { - Apreender as seguintes noções fundamentais ao } \\
\text { entendimento do conteúdo básico proposto: } \\
\text { diversidades naturais/ocupação econômica; } \\
\text { diversidades regionais/desenvolvimento } \\
\text { econômico; blocos econômicos/alianças } \\
\text { políticas. }\end{array}$ \\
\hline $\begin{array}{l}\text { III. A UNIÃO SOVIÉTICA } \\
\text { 3.1 Aspectos históricos da formação do } \\
\text { Estado Soviético. } \\
\text { 3.2 Características físicas básicas e as } \\
\text { questões ambientais. } \\
\text { 3.3 Características básicas da economia } \\
\text { e os reflexos no contexto internacional; } \\
\text { 3.4 A população: composição étnica. }\end{array}$ & $\begin{array}{l}\text { - Identificar o Estado Soviético como resultante } \\
\text { da aglutinação de várias nações; } \\
\text { - Identificar a organização econômica, política e } \\
\text { cultural da URSS e primeiro país organizado } \\
\text { sob os princípios socialistas; } \\
\text { - Apreender as seguintes noções fundamentais ao } \\
\text { entendimento dos conteúdos básico proposto: } \\
\text { Revolução socialista, etnia e nacionalidade, } \\
\text { coletividade, planificação econômica e } \\
\text { estatização. }\end{array}$ \\
\hline
\end{tabular}




\begin{tabular}{|c|c|}
\hline $\begin{array}{l}\text { IV. CHINA } \\
\text { 4.1 A experiência socialista na China; } \\
\text { 4.2 Aspectos da organização da } \\
\text { produção. } \\
\text { 4.3 População: política demográfica }\end{array}$ & $\begin{array}{l}\text { - Analisar a experiência socialista na China, as } \\
\text { formas de organização da produção e o trato de } \\
\text { organização da produção e o trato com as } \\
\text { questões da população; } \\
\text { - Apreender as seguintes noções fundamentais ao } \\
\text { entendimento dos conteúdos básico proposto: } \\
\text { cooperativismo, comunas populares, } \\
\text { agricultura de jardinagem. }\end{array}$ \\
\hline $\begin{array}{l}\text { V. O JAPÃO } \\
5.1 \text { Evolução histórica e posição } \\
\text { econômica contemporânea. } \\
5.2 \text { Aspectos físicos, econômicos e } \\
\text { sociais. }\end{array}$ & $\begin{array}{l}\text { - Identificar o Japão enquanto potência } \\
\text { econômica mundial, sua posição estratégica, os } \\
\text { contrastes naturais, suas características físicas e } \\
\text { os problemas decorrentes: recursos e } \\
\text { tecnologia, organização da produção e relações } \\
\text { de trabalho. }\end{array}$ \\
\hline $\begin{array}{l}\text { VI. A AMERICA ANGLO- } \\
\text { SAXÔNICA } \\
\text { 6.1 A natureza e a organização do } \\
\text { espaço. } \\
\text { 6.2 A população - Canadá e Estados } \\
\text { Unidos - questões. } \\
\text { 6.3 Contexto econômico, político e } \\
\text { social dos EUA e Canadá. }\end{array}$ & $\begin{array}{l}\text { - Identificar os diferentes países da América } \\
\text { Anglo-Saxônica como um todo e a organização } \\
\text { econômica resultante da ação do homem sobre } \\
\text { a natureza; } \\
\text { - Caracterizar os EUA como potência econômica } \\
\text { mundial e suas relações internacionais; } \\
\text { - Apreender as seguintes noções fundamentais ao } \\
\text { entendimento do conteúdo básico proposto: } \\
\text { automação industrial; sociedade de consumo, } \\
\text { tecnologia, mecanização agrícola, questões } \\
\text { raciais. }\end{array}$ \\
\hline $\begin{array}{l}\text { VII. AFRICA } \\
\text { 7.1 A África ontem e a África hoje. } \\
\text { 7.2 Domínios naturais do continente. } \\
\text { 7.3 Aspectos econômicos, políticos e } \\
\text { culturais. }\end{array}$ & $\begin{array}{l}\text { - Analisar o processo colonial no continente e } \\
\text { suas conseqüências na organização política; } \\
\text { - Identificar as diferentes paisagens naturais } \\
\text { relacionando ao processo de ocupação; } \\
\text { - Discutir o processo de descolonização no } \\
\text { continente e os reflexos das reformas atuais de } \\
\text { organização política e econômica; } \\
\text { - Apreender as seguintes noções fundamentais ao } \\
\text { entendimento do conteúdo básico proposto: } \\
\text { colonização/descolonização; sociedade tribal, } \\
\text { estados nacionais; organização/desorganização } \\
\text { das atividades produtivas. }\end{array}$ \\
\hline $\begin{array}{l}\text { VIII. O ORIENTE MÉDIO } \\
\text { 8.1 Posição geográfica e identidade } \\
\text { cultura. } \\
8.2 \text { Conflitos étnico-religiosos. } \\
8.3 \text { Aspectos econômicos e relações de } \\
\text { dependência. }\end{array}$ & $\begin{array}{l}\text { - Caracterizar o Oriente Médio enquanto área } \\
\text { geográfica que extrapola limites continentais; } \\
\text { - Situar o Oriente Médio enquanto área com } \\
\text { identidade cultural que tem o islamismo como } \\
\text { referencial mas que por interesses exteriores a } \\
\text { sua realidade está submetido às mais diferentes } \\
\text { forma de conflitos; } \\
\text { - Apreender as seguintes noções fundamentais ao } \\
\text { entendimento do conteúdo básico proposto: } \\
\text { petróleo - riqueza estranha à população; } \\
\text { islamismo; conflitos étnico-religiosos. }\end{array}$ \\
\hline
\end{tabular}


Série: $\mathbf{8}^{\mathbf{a}}$

Carga horária: 72 horas +18 horas destinadas à revisão, à verificação e a provas (total: 90 horas)

Objetivo Geral da disciplina: Compreender as características gerais e regionais do continente latino-americano, inserindo-o no contexto internacional e analisando-o em seus aspectos naturais, econômicos, sociais e políticos; compreender o Brasil como país latino-americano analisando seus aspectos naturais, econômicos, sociais, políticos a nível geral de suas diferenciações regionais.

\begin{tabular}{|c|c|}
\hline CONTEÚDO PROGRAMADO & OBJETIVOS ESPECÍFICOS \\
\hline $\begin{array}{l}\text { I. AMERICA LATINA: introdução } \\
\text { 1.1 As bases históricas: dependência } \\
\text { econômica e herança cultural. } \\
\text { 1.2Contexto social, político e } \\
\text { econômico. } \\
\text { 1.3 As relações com os EUA e Europa }\end{array}$ & $\begin{array}{l}\text { - Analisar o contexto latino-americano nos } \\
\text { quadros de sua relação histórica com o mundo } \\
\text { desenvolvido. }\end{array}$ \\
\hline $\begin{array}{l}\text { II. AMÉRICA LATINA: aspectos } \\
\text { físicos } \\
2.1 \text { Características da estrutura } \\
\text { geológica, do relevo e do seu } \\
\text { aproveitamento. } \\
\text { 2.2 As grandes } \\
\text { paisagens climatobotânicos. }\end{array}$ & $\begin{array}{l}\text { - Identificar as características gerais do espaço } \\
\text { físico latino-americano, com destaque para o } \\
\text { caso brasileiro; }\end{array}$ \\
\hline $\begin{array}{l}\text { III.MÉXICO E AMÉRICA CENTRAL } \\
\text { 3.1 Características humanas } \\
\text { e econômicas. } \\
\text { 3.2 A importância política } \\
\text { na conjuntura internacional. }\end{array}$ & $\begin{array}{l}\text { - Identificar as características gerais do espaço } \\
\text { mexicano e centro-americano; } \\
\text { - Compreender a importância da região no } \\
\text { contexto internacional, destacando a influência } \\
\text { norte-americana e as tentativas de ruptura. }\end{array}$ \\
\hline $\begin{array}{l}\text { IV. AMERICA DO SUL } \\
4.1 \text { O espaço sul-americano, suas } \\
\text { divisões e a organização regional da } \\
\text { economia. } \\
4.2 \text { A população e a diversidade } \\
\text { cultural. }\end{array}$ & $\begin{array}{l}\text { - Identificar as grandes unidades regionais; } \\
\text { - Destacar os traços culturais comuns da } \\
\text { América do Sul, bem como as características } \\
\text { gerais da população do continente. }\end{array}$ \\
\hline $\begin{array}{l}\text { V.BRASIL no contexto da América } \\
\text { Latina } \\
\text { 5.1. O Brasil como parte integrante da } \\
\text { América Latina: o político, o } \\
\text { econômico e o cultural; } \\
\text { 5.2.As relações de Brasil com os } \\
\text { demais países da América Latina. }\end{array}$ & $\begin{array}{l}\text { - Destacar os processos convergentes que } \\
\text { identificam o Brasil no contexto latino- } \\
\text { americano; } \\
\text { - Analisar a situação atual das relações do Brasil } \\
\text { com os demais países do continente } \\
\text { identificando algumas tentativas de integração } \\
\text { continental. }\end{array}$ \\
\hline
\end{tabular}




\begin{tabular}{|c|c|}
\hline $\begin{array}{l}\text { VI. A população brasileira } \\
\text { 6.1. Aspectos da estrutura do } \\
\text { crescimento e da distribuição. } \\
\text { 6.2. As imigrações internas e a } \\
\text { presença de imigrante estrangeiro. } \\
\text { 6.3. A diversidade étnica e questão } \\
\text { racial. }\end{array}$ & $\begin{array}{l}\text { - Analisar o processo de formação da população } \\
\text { brasileira, bem como sua economia e } \\
\text { distribuição espacial na atualidade; } \\
\text { - Identificar os diferentes grupos que compõe a } \\
\text { população brasileira; } \\
\text { - Analisar o processo de crescimento } \\
\text { populacional no Brasil; } \\
\text { - Analisar a diferenciação interna da população } \\
\text { brasileira, do ponto de vista que a mesma. }\end{array}$ \\
\hline $\begin{array}{l}\text { VII. O espaço de produção do Brasil } \\
\text { 7.1. As atividades agrícolas e de } \\
\text { criação; } \\
\text { 7.2. As atividades industriais; } \\
\text { 7.3. O comércio e os serviços. }\end{array}$ & $\begin{array}{l}\text { - Analisar as principais características da } \\
\text { produção agropecuária brasileira; } \\
\text { - Compreender as características e a dinâmica do } \\
\text { setor industrial, bem como da circulação de } \\
\text { mercadorias e dos serviços públicos. }\end{array}$ \\
\hline $\begin{array}{l}\text { VIII. A organização dos espaços } \\
\text { regionais } \\
\text { 8.1. A regionalização oficial do Brasil; } \\
\text { 8.2. O processo histórico de formação } \\
\text { das regiões e a nova divisão regional; } \\
\text { 8.3. O Centro-Sul } \\
\text { A Concentração do capital e a } \\
\text { centralização do poder; } \\
\text { O processo de industrialização; } \\
\text { A urbanização e a questão das } \\
\text { metrópoles; } \\
\text { As atividades agropecuárias, o } \\
\text { processo de modernização e a questão } \\
\text { da Terra. } \\
\text { 8.4. O Nordeste } \\
\text { A população Nordestina e o problema } \\
\text { social; } \\
\text { A Natureza: diferentes de potencial a } \\
\text { ser explorado; } \\
\text { As atividades econômicas. }\end{array}$ & $\begin{array}{l}\text { - Reconhecer a regionalização tradicional do } \\
\text { Brasil, chamado atenção para o caráter } \\
\text { dinâmico da formação regional no Brasil; } \\
\text { - Compreender o Centro-Sul no contexto da } \\
\text { economia brasileira; } \\
\text { - Analisar os principais traços da modernização } \\
\text { do Centro-Sul, ressaltando o caráter } \\
\text { diferenciado deste processo pelos diversos } \\
\text { setores de economia e da vida social; } \\
\text { - Destacar o problema nordestino, referenciando- } \\
\text { o à estrutura econômica regional e à relação } \\
\text { com as demais regiões; } \\
\text { Analisar as condições naturais da região } \\
\text { nordeste, em termos dos obstáculos oferecidos } \\
\text { ao desenvolvimento, bem como as } \\
\text { potencialidades ambos inexplorados. }\end{array}$ \\
\hline
\end{tabular}

Podemos analisar que neste plano de ensino a preocupação está centrada no excesso de conteúdos, não há uma adequação destes com o cotidiano do aluno. Foi desenvolvido para trabalhar conceitos gerais da disciplina sem uma interligação com os aspectos relacionados aos acontecimentos da época, da realidade local ou nacional.

Percebemos os conceitos espaço, paisagem, território, região, escala, meio ambiente relacionados à questão econômica na organização do espaço. A relação da influência do marxismo para constituir um programa diferenciado de ensino de geografia, pois desde o currículo de 1982 temos, de certa maneira, interligações com os acontecimentos atuais e a inserção de conteúdos que modelam e transformam o espaço: a questão do espaço urbano, do meio ambiente, as transformações na paisagem, a 
organização social e política da população, o entendimento dos processos históricogeográficos do mundo, o embate do socialismo X capitalismo.

Ao mesmo tempo em que há um ordenamento dos conceitos voltados aos fatos geográficos, continua o processo de fragmentação dos mesmos, a característica ainda é direcionados N-H-E com uma nítida separação entre a Humana e a Física situando os outros elementos. A cartografia se torna um eixo elementar no ensino da Geografia, mas ainda o instrumental, sem ser uma questão analítica, de construção desse para as relações do cotidiano do aluno, ou efetivamente uma alfabetização cartográfica.

A observação também é feita nos conteúdos de Geografia do Brasil visto na $8^{\text {a }}$ série depois de caracterizar as Américas e, uma continuação sobre o nosso território, caracterizado pelos aspectos econômicos, visíveis na própria regionalização deste na qual está descrita a forma oficial pelo IBGE, porém o aprofundamento se dá pela discussão da Região Geoeconômica de Pedro Geiger. Nesta perspectiva, o estudo atual do Brasil passa a ter um foco menor e a centralização ocorre nos termos gerais da disciplina. Os conteúdos são mais técnicos e há uma dimensão relacionada às questões mundiais, principalmente do Homem e do Trabalho, a todos os fatores econômicos. Não há valorização do espaço vivido, mas o somente produzido de maneira estanque. A relação do homem se torna mais dinâmica (a destacar que ele participa da organização da transformação do espaço, porém sem uma inter-relação entre o homem - sociedade que é também o homem - pai, mãe e o próprio aluno - os quais intervêm ou está inserido nessas mudanças), como um ser histórico-geográfico-biológico-social-político.

Apesar da contextualização dos fatos geográficos, de um salto qualitativo nos primeiros currículos, de concepção geográfica para a década de 90 é revelar também um currículo prescrito pelo que há de importante em pensar o ensino do aluno, como a geografia intervém para a compreensão do cotidiano. A falta de elo entre a realidade vivida e o ensino de geografia ainda permeia os currículos, uma tradição antiga.

\author{
MEC_Colégio Pedro II \\ Secretaria de Ensino \\ Plano de Curso \\ Disciplina: Geografia
}

Ano: 1982

Série: $5^{\mathbf{a}}$

Carga horária: 90 horas 
Objetivo Geral da disciplina: Proporcionar ao educando uma compreensão de como os homens, acumulando conhecimentos e técnicas, têm superado as dificuldades do meio, aproveitando os recursos da natureza, e de como os grupos humanos, expandindo-se sobre a Terra, têm propagado sua cultura e suas formas de organização econômica e social.

PLANO ELABORA PELA EQUIPE DE COORDENADORES DA DISCIPLINA

\begin{tabular}{|c|c|c|}
\hline \begin{tabular}{|l|} 
UNIDADES \\
DIDÁTICAS \\
\end{tabular} & CONTEÚDO PROGRAMADO & \begin{tabular}{|l|}
$\mathrm{N}^{\circ} \mathrm{DE}$ \\
$\mathrm{AULAS}$ \\
\end{tabular} \\
\hline $\begin{array}{l}1.0 \\
1.1 \\
1.2 \\
1.3\end{array}$ & $\begin{array}{l}\text { A TERRA, MORADA DO HOMEM } \\
\text { A Terra e o Universo: movimentos da Terra e suas conseqüências } \\
\text { Orientações na superfície terrestre } \\
\text { Representações da superfície terrestre }\end{array}$ & 20 \\
\hline $\begin{array}{l}2.0 \\
2.1 \\
2.2 \\
2.3\end{array}$ & $\begin{array}{l}\text { O MEIO GEOGRÁFICO } \\
\text { A crosta, a morfologia e a drenagem } \\
\text { A cobertura vegetal e os solos } \\
\text { Oceanos e mares }\end{array}$ & 20 \\
\hline $\begin{array}{l}3.0 \\
3.1 \\
3.2 \\
3.3\end{array}$ & $\begin{array}{l}\text { O HOMEM E O MEIO } \\
\text { Os recursos naturais e sua utilização } \\
\text { O mar como fronteira de exploração econômica } \\
\text { Degradação e melhoria do meio ambiente }\end{array}$ & 10 \\
\hline $\begin{array}{l}4.0 \\
4.1 \\
4.2 \\
4.3\end{array}$ & $\begin{array}{l}\text { A REPARTIÇÃO DOS HOMENS SOBRE A TERRA } \\
\text { A distribuição da população na superfície terrestre e suas condições } \\
\text { naturais } \\
\text { O crescimento demográfico; os grandes movimentos migratórios e seu } \\
\text { papel na conquista do espaço geográfico } \\
\text { As etnias, as línguas e as religiões }\end{array}$ & 12 \\
\hline $\begin{array}{l}5.1 \\
5.2 \\
5.3\end{array}$ & $\begin{array}{l}\text { OS GRUPOS HUMANOS - SUAS ATIVIDADES ECONÔMICAS E } \\
\text { SUA ORGANIZAÇÃO NA SUPERFÍCIE TERRESTRE } \\
\text { O mundo rural, as sociedades primitivas, tradicionais e modernas } \\
\text { Características geográficas da civilização industrial } \\
\text { A urbanização e suas conseqüências }\end{array}$ & 12 \\
\hline & Aulas destinadas à revisão, verificação e provas & 16 \\
\hline \begin{tabular}{|l|} 
UNIDADES \\
DIDÁTICAS \\
\end{tabular} & \multicolumn{2}{|l|}{ OBJETIVOS ESPECÍFICOS POR UNIDADE DIDÁTICA } \\
\hline 1.0 & \multicolumn{2}{|c|}{$\begin{array}{l}\text { Compreender a Terra, a morada do Homem, como parte do Universo Cósmico, de } \\
\text { modo especial, como parte do Sistema Solar; } \\
\text { Compreender como as condições básicas que regulam a vida do Homem e dos } \\
\text { demais seres vivos sobre o Globo são consequiências da energia solar e dos } \\
\text { movimentos que a Terra executa no espaço; } \\
\text { Compreender os fundamentos das técnicas de representação da superfície terrestre e } \\
\text { os modos de orientação sobre a mesma superfície. }\end{array}$} \\
\hline 2.0 & \multicolumn{2}{|c|}{$\begin{array}{l}\text { Compreender o meio geográfico como uma combinação de fatos naturais e culturais } \\
\text { a qual difere de lugar na superfície terrestre; } \\
\text { Caracterizar os elementos que compõem o quadro natural em que vive o Homem. }\end{array}$} \\
\hline
\end{tabular}




\begin{tabular}{|c|c|}
\hline 3.0 & $\begin{array}{l}\text { Compreender como o Homem, pelo seu trabalho e pelas técnicas que desenvolve, } \\
\text { obtém na natureza os recursos básicos para sua subsistência e para o } \\
\text { desenvolvimento material da sociedade; } \\
\text { Compreender como os grupos humanos, inadvertidamente, podem desperdiçar } \\
\text { recursos ou, previdentemente, conservá-los e renová-los, do mesmo modo que } \\
\text { podem degradar ou melhorar o meio ambiente em que vivem. }\end{array}$ \\
\hline 4.0 & $\begin{array}{l}\text { Identificar as principais condições naturais, culturais e econômicas que explicam a } \\
\text { grande desigualdade da distribuição da população sobre o Globo; } \\
\text { Caracterizar as formas de movimentos migratórios e de crescimento que tornam a } \\
\text { distribuição da população um fato dinâmico; } \\
\text { Identificar as características étnicas, lingüísticas e religiosas que distinguem os } \\
\text { grupos humanos entre si. }\end{array}$ \\
\hline 5.0 & $\begin{array}{l}\text { Compreender como os grupos humanos, pelas suas atividades econômicas e pelas } \\
\text { suas características culturais básicas se constituem em diferentes formas de } \\
\text { sociedade; } \\
\text { Reconhecer as atividades agropastoris como base da vida rural e como estruturadas } \\
\text { de sociedades em estágios diferentes; } \\
\text { Reconhecer as atividades industriais como estruturadoras da economia } \\
\text { contemporânea, de uma forma peculiar de civilização e, conseqüentemente, de } \\
\text { características geográficas próprias. }\end{array}$ \\
\hline
\end{tabular}

\section{ESTRATÉGIA DIDÁTICO-PEDAGÓGICA}

- Uso de quadro de giz

- Aulas expositivas

- Uso do livro-texto

- Atlas geográfico, mapas e murais

- Globo terrestre

- Debates

- Estudo dirigido

- Recursos áudios-visuais

- Excursões, se possível.

\section{Série: $6^{\mathrm{a}}$}

Objetivo Geral da disciplina: Proporcionar ao educando a compreensão das características gerais do Mundo atual, através do estudo dos grandes conjuntos regionais da superfície terrestre e do processo histórico que as levou às atuais formas de organização social, política e econômica pelos grupos humanos que as habitam.

PLANO ELABORADO PELA EQUIPE DE COORDENADORES DA DISCIPLINA

\begin{tabular}{|l|l|l|}
\hline UNIDADES & CONTEÚDO PROGRAMADO & $\begin{array}{l}\mathrm{N}^{\circ} \text { DE } \\
\text { AULASICAS }\end{array}$ \\
\hline
\end{tabular}




\begin{tabular}{|c|c|c|}
\hline \begin{tabular}{|l|}
1.0 \\
1.1
\end{tabular} & $\begin{array}{l}\text { AS CARACTERÍSTICAS GERAIS DO MUNDO ATUAL } \\
\text { Os grandes quadros naturais e seu significado para a evolução da } \\
\text { Humanidade: as massas continentais e marítimas; as bacias fluviais e } \\
\text { lacustres e as zonas bioclimáticas; } \\
\text { A evolução crescente da Humanidade e as principais características } \\
\text { culturais, políticas, econômicas e espaciais decorrentes: a formação da } \\
\text { sociedade industrial e o colonialismo; o desenvolvimento e o } \\
\text { subdesenvolvimento e os grandes regimes políticos e econômicos. }\end{array}$ & 12 \\
\hline $\begin{array}{l}2.0 \\
2.1 \\
2.2\end{array}$ & $\begin{array}{l}\text { OS PAÍSES RICOS DO MUNDO CAPITALISTA } \\
\text { Os fundamentos geográficos de cada potência: Anglo-América, da } \\
\text { Europa Ocidental e o Japão; } \\
\text { O papel das nações industrializadas na economia e nos assuntos } \\
\text { internacionais. }\end{array}$ & 18 \\
\hline \begin{tabular}{|l}
3.0 \\
3.1 \\
3.2 \\
3.3 \\
3.4
\end{tabular} & $\begin{array}{l}\text { O BLOCO SOCIALISTA EURASIÁTICOS } \\
\text { A formação histórica do Mundo Socialista; } \\
\text { Os fundamentos da organização política e econômica socialista; } \\
\text { Visão das suas relações internacionais; } \\
\text { As peculiaridades geográficas da URSS e da Europa Oriental. }\end{array}$ & 14 \\
\hline $\begin{array}{l}4.0 \\
4.1 \\
4.2\end{array}$ & $\begin{array}{l}\text { O TERCEIRO MUNDO (I) } \\
\text { As condicionantes geográficas do Mundo Subdesenvolvido; } \\
\text { As áreas culturais e os contrastes no "Terceiro Mundo": A América } \\
\text { Latina. }\end{array}$ & 12 \\
\hline \begin{tabular}{|l|}
5.0 \\
5.1
\end{tabular} & $\begin{array}{l}\text { O TERCEIRO MUNDO (II) } \\
\text { As áreas culturais e os contrastes no "Terceiro Mundo: África Negra, } \\
\text { Países Islâmicos, Ásia Meridional e Oriental. }\end{array}$ & 16 \\
\hline & Aulas destinadas à revisão, verificação e provas & 18 \\
\hline
\end{tabular}

\begin{tabular}{|c|c|}
\hline $\begin{array}{l}\text { UNIDADES } \\
\text { DIDÁTICAS }\end{array}$ & OBJETIVOS ESPECÍFICOS POR UNIDADE DIDÁTICA \\
\hline 1.0 & $\begin{array}{l}\text { Caracterizar as condições naturais correlacionando-as com as ocupação humana } \\
\text { e as formas de organização do espaço; } \\
\text { Correlacionar a Revolução Industrial e o Colonialismo com o Desenvolvimento e } \\
\text { o Subdesenvolvimento; } \\
\text { Reconhecer os reflexos da } 2^{\text {a }} \text { Guerra no processo da descolonização e na } \\
\text { organização as Comunidades Econômicas e Políticas; } \\
\text { Identificar as principais características dos regimes políticos e econômicos do } \\
\text { Mundo Atual. }\end{array}$ \\
\hline 2.0 & $\begin{array}{l}\text { Reconhecer as peculiaridades do quadro natural da Anglo-América, da Europa } \\
\text { Ocidental e do Japão e as características sócio-econômicas fundamentais dessas } \\
\text { áreas; } \\
\text { Identificar as formas de influência econômica e política das nações } \\
\text { industrializadas no quadro geral e, em especial, nos países subdesenvolvidos. }\end{array}$ \\
\hline 3.0 & $\begin{array}{l}\text { Reconhecer os aspectos gerais da formação histórica e os fundamentos da } \\
\text { organização política e econômicas nos países socialistas; } \\
\text { Localizar espacialmente a expansão do regime socialista; } \\
\text { Identificar as peculiaridades geográficas das URSS e da Europa Oriental }\end{array}$ \\
\hline 4.0 & $\begin{array}{l}\text { Reconhecer as condições naturais, sócio-econômicas e históricas do Mundo } \\
\text { Subdesenvolvido; } \\
\text { Identificar os principais aspectos geográficos das grandes unidades regionais da } \\
\text { América Latina: a Amazônia, a América Andina, a América Platina, a América } \\
\text { Central e o México. }\end{array}$ \\
\hline
\end{tabular}




\begin{tabular}{|l|l|}
\hline 5.0 & $\begin{array}{l}\text { Identificar os aspectos geográficos da África Negra, Países Islâmicos, Ásia } \\
\text { Meridional e Oriental, salientando os contrastes culturais e sócio-econômicos } \\
\text { existentes em cada uma dessas áreas. }\end{array}$
\end{tabular}

\section{ESTRATÉGIA DIDÁTICO-PEDAGÓGICA}

- Uso de quadro de giz

- Aulas expositivas

- Uso do livro-texto

- Atlas geográfico, mapas e murais

- Globo terrestre

- Debates

- Estudo dirigido

- Recursos áudios-visuais

- Excursões, se possível.

\section{$7^{\mathrm{a}}$ série}

Objetivos gerais: Compreender as características gerais do Brasil analisando seus aspectos naturais, econômicos, sociais, políticos a nível geral de suas diferenciações regionais.

\begin{tabular}{|c|c|c|}
\hline $\begin{array}{l}\text { UNIDADES } \\
\text { DIDÁTICAS }\end{array}$ & CONTEÚDO PROGRAMADO & $\begin{array}{l}\mathrm{N}^{\circ} \mathrm{DE} \\
\text { AULAS }\end{array}$ \\
\hline 1.0 & BRASIL: VISÃO DE CONJUNTO & 16 \\
\hline 1.1 & Espaço e posição; & \\
\hline 1.2 & As condições naturais; & \\
\hline 1.3 & O efetivo humano; & \\
\hline 1.4 & As atividades econômicas; & \\
\hline 1.5 & A organização regional brasileira: as macro-regiões geoeconômicas. & \\
\hline 2.0 & O SUDESTE e a concentração do desenvolvimento nacional; & 14 \\
\hline $\begin{array}{l}2.2 \\
2.3\end{array}$ & $\begin{array}{l}\text { A diversidade do quadro agrário: características naturais e relações com } \\
\text { os mercados produtores e consumidores: as áreas agrícolas mais } \\
\text { expressivas; } \\
\text { A industrialização e seus efeitos. As principais áreas urbano-industriais; } \\
\text { O papel do Sudeste na organização espacial do país. }\end{array}$ & \\
\hline 3.0 & O SUL: um espaço subtropical & 10 \\
\hline 3.1 & Populações e movimentos migratórios; & \\
\hline 3.2 & $\begin{array}{l}\text { Contrastes sócio-econômicos: áreas de pequenas propriedades } \\
\text { policultoras e de grandes estabelecimentos agro-pastoris; }\end{array}$ & \\
\hline 3.3 & Características das atividades industriais; & \\
\hline 3.4 & Principais centros regionais. & \\
\hline 4.0 & O NORDESTE: pressão sobre os recursos naturais & 12 \\
\hline 4.1 & Dualidade regional: as áreas úmidas do Litoral e as semi-áridas do Sertão; & \\
\hline 4.2 & $\begin{array}{l}\text { Os problemas sócio-econômicos e os esforços governamentais para } \\
\text { solucioná-los. }\end{array}$ & \\
\hline 5.0 & O CENTRO-OESTE, região de transição & 10 \\
\hline 5.1 & Os grandes espaços vazios no interior do Brasil (cerrados e chapadões); & \\
\hline & Articulação do Centro-Oeste com as demais regiões do País. A parte Sul: & \\
\hline 5.2 & reflexo do dinamismo do Centro-Sul. A parte Norte: contactos com os & \\
\hline 5.3 & domínios amazônicos. & \\
\hline 5.4 & Brasília e a sua importância na integração nacional & \\
\hline
\end{tabular}




\begin{tabular}{|l|l|l|}
\hline 6.0 & $\begin{array}{l}\text { A AMAZÔNIA, recursos abundantes, extensa superfície e escassa } \\
\text { população. }\end{array}$ & 10 \\
6.1 & As formas de ocupação, o desafio da natureza e os problemas ecológicos; & \\
6.2 & O papel da Amazônia na integração nacional e continental & \\
\hline & Aulas destinadas à revisão, verificação e provas & 18 \\
\hline
\end{tabular}

\begin{tabular}{|c|c|}
\hline \begin{tabular}{|l} 
UNIDADES \\
DIDÁTICAS
\end{tabular} & OBJETIVOS ESPECÍFICOS POR UNIDADE DIDÁTICA \\
\hline 1.0 & $\begin{array}{l}\text { Identificar as conseqüências decorrentes do ESPAÇO e da POSIÇÃO DO Brasil; } \\
\text { Caracterizar os grandes domínios naturais, ressaltando a presença do homem } \\
\text { nessas paisagens; } \\
\text { Reconhecer as características da distribuição espacial da população, destacando o } \\
\text { papel dos fluxos migratórios internos e externos; } \\
\text { Identificar os problemas agrários, o processo da industrialização e da } \\
\text { urbanização; } \\
\text { Identificar as macro-regionais brasileiras, reconhecendo-as como formas de } \\
\text { organização do espaço. }\end{array}$ \\
\hline 2.0 & $\begin{array}{l}\text { Identificar os fatores responsáveis pelo dinamismo da Região Sudeste, } \\
\text { reconhecendo a importância da cultura cafeeira no desenvolvimento } \\
\text { socioeconômico regional; } \\
\text { Localizar as principais áreas agrícolas, relacionando-as com os mercados } \\
\text { consumidores; } \\
\text { Identificar os fatores responsáveis pela localização industrial no Sudeste e as } \\
\text { principais áreas urbano-industriais. }\end{array}$ \\
\hline 3.0 & $\begin{array}{l}\text { Relacionar a subtropicalidade da Região Sul com as formas originais de uso da } \\
\text { terra e do povoamento; } \\
\text { Reconhecer os contrastes na ocupação do solo, seus reflexos na industrialização } \\
\text { e na urbanização e o papel das migrações no desenvolvimento sócio-econômico } \\
\text { regional; } \\
\text { Localizar espacialmente os principais centros regionais relacionando-os com a } \\
\text { imigração européia. }\end{array}$ \\
\hline 4.0 & $\begin{array}{l}\text { Caracterizar o Litoral, o Agreste e o Sertão nordestinos e respectivas formas de } \\
\text { aproveitamento econômico; } \\
\text { Identificar os principais problemas sócio-econômicos do Nordeste e os fatores } \\
\text { por eles responsáveis; } \\
\text { Destacar o papel das Sudene no desenvolvimento regional. }\end{array}$ \\
\hline 5.0 & $\begin{array}{l}\text { Reconhecer o Centro-Oeste como reserva territorial para a expansão da fronteira } \\
\text { econômica nacional; } \\
\text { Caracterizar os diferentes elementos do quadro natural do Centro-Oeste, } \\
\text { relacionando-os com a organização econômica do espaço; } \\
\text { Identificar os principais fatores do crescimento demográfico e econômico do } \\
\text { Centro-Oeste, ressaltando o papel de instalação de Brasília. }\end{array}$ \\
\hline 6.0 & $\begin{array}{l}\text { Reconhecer a Amazônia como um grande espaço subpovoado, destacando as } \\
\text { formas de ocupação e os problemas ecológicos decorrentes; } \\
\text { Localizar espacialmente as principais áreas de exploração mineral, ressaltando a } \\
\text { sua importância no desenvolvimento econômico da região; } \\
\text { Reconhecer o papel da Sudam no desenvolvimento da Amazônia, destacando a } \\
\text { política de integração nacional e continental. }\end{array}$ \\
\hline
\end{tabular}

\section{ESTRATÉGIA DIDÁTICO-PEDAGÓGICA}

- Uso de quadro de giz

- Aulas expositivas

- Uso do livro-texto 
- Atlas geográfico, mapas e murais

- Globo terrestre

- Debates

- Estudo dirigido

- Recursos áudios-visuais

- Excursões, se possível.

OBS: A $8^{a}$ SÉRIE passou fazer parte da divisão escolar de geografia em 1983.

$\mathrm{Na}$ análise deste plano, o ensino fundamental tinha três séries, dividido em três partes: duas partes direcionadas às características gerais do mundo, e a última série o debate sobre o Brasil. Analisando os objetivos gerais e os específicos, pontuamos que a concepção geográfica mudou em relação ao plano de 1951, pois percebemos uma interligação com os acontecimentos da época, apesar de uma discussão fragmentada NH-E e alguns conceitos de geografia tradicional; uma discussão econômica e dividindo os conteúdos em rural, indústria e urbano; as divisões do mundo conforme os países ricos - capitalistas $\left(1^{\circ}\right.$ mundo), socialista $\left(2^{\circ}\right.$ mundo) e países pobres capitalistas $\left(3^{\circ}\right.$ mundo), condicionando os conteúdos às condições naturais, na correlação das revoluções industriais, nos conflitos das guerras mundiais, outras formas de regionalizar o mundo tomando como base os aspectos culturais e principalmente econômicos.

Atentamos para os conceitos: meio geográfico (possibilista), espaço, região e território, meio ambiente que estão apesar de uma discussão "crítica", relacionados ao método regional de classificação do espaço geográfico.

Há um excesso de conteúdo não focado na experiência e cotidiano dos alunos, mas uma disciplina com elementos de uma geografia universitária.

Apontado para os conteúdos do Brasil, observando uma divisão das regiões brasileiras como regiões homogêneas e a classificação do IBGE, os aspectos do padrão $\mathrm{N}-\mathrm{H}-\mathrm{E}$ com destaque em relacionar os aspectos urbano-industriais a características físicas e econômicas de cada região, expressando uma reprodução de conteúdos sem relação com o cotidiano do aluno. Apesar de uma discussão descritiva do espaço mundo e brasileiro, conforme destaque Moreira (1987) a preocupação em caracterizar um país continental, limitados pelos aspectos físicos, divididos por aspectos naturais, humanos e econômicos sem uma integração entre ambos. 
Programa de Ensino - 1951

\section{Geografia Geral - Curso ginasial}

$\mathbf{1}^{\mathbf{a}}$ série
Geografia Física e Humana
I. A Terra no espaço
II. Estrutura da Terra
III. Os grupos humanos
IV. A circulação
V. A agricultura e a pecuária
VI. Indústria e comércio

\section{$2^{\mathrm{a}}$ série}

Geografia Geral

I. Os continentes. As regiões polares

II. A América do Norte

III. A América Central e as Antilhas

IV. A América do Sul. Países Andinos

V. A Argentina. Paraguai. Uruguai.

VI. A Europa Setentrional

VII. A Europa Meridional

VIII. A Europa Ocidental

IX. O Egito. Partilha do continente africano colônia européia

X. A Ásia Oriental

XI. A Ásia Meridional e Ásia Ocidental

XII. A Austrália

De cada destes itens se fará o seguinte estudo:
a) Estrutura fisiográfico.
b) Regiões naturais
c) Populações, raças e religião.
d) Cidades principais e recursos econômicos.

\begin{tabular}{|l|}
\hline $3^{\mathbf{a}}$ série \\
Geografia Física e Humana do Brasil \\
\\
I. O espaço brasileiro \\
II. A população brasileira \\
III.Organização política e \\
administrativa
\end{tabular}

\section{$4^{a}$ série}

Geografia Regional do Brasil

I. Divisão regional. O conceito de região natural. As regiões brasileiras.

Região Norte

III. Região Nordeste

IV. Região Leste

IV. Circulação e sistema de viação

V. A produção agrícola

VI. Produção mineral e animal

VII. Indústria e comércio

V. Região Meridional

VI. Região Centro - Oeste

O estudo de cada região obedecerá aos seguintes itens.
a) Descrição fisiográfica.
b) Povoamento.
c) Divisão dos estados
d) Recursos econômicos
e) Circulação. 
Analisando o currículo de 1951, percebemos conforme Moreira (1987) uma fragmentação do padrão N-H-E, no qual a ênfase se direciona principalmente nas discussões físicas, depois da população e economia. É nesse currículo que está escrito a discussão do conceito de espaço, a região ainda vista como natural e o território solo.

Os conteúdos estão relacionados a estrutura da Terra, aos grupos humanos e à economia na $1^{\mathrm{a}}$ série, ou seja, aspetos gerais sobre Geografia física e humana dicotomia elementar na Geografia. $\mathrm{Na} 2^{\mathrm{a}}$ série Geografia geral direcionada à divisão dos continentes no mesmo padrão físico, humano e econômico. $\mathrm{Na} 3^{\mathrm{a}}$ série, a Geografia Física e Humana do Brasil, com os elementos do espaço brasileiro, população e os aspectos econômicos e no $4^{\circ}$ ano, a seqüência do Brasil como foco as Regiões Naturais obedecendo ao padrão N-H-E. A estrutura dos conteúdos do Brasil.

Percebemos a introdução da indústria e de um novo conceito de organização regional para o Brasil, com um aprofundamento da discussão sobre este. Não aparece a discussão sobre a cidade e o urbano, a interligação da N-H-E mas uma fragmentação acentuada, a relação da população sem um estudo sobre como o ser humano intervém, manipula e transforma o espaço em que vive.

Analisando o contexto da época, o planeta já tinha passado por duas guerras mundiais, pela guerra fria, a descolonização africana, a industrialização nos países subdesenvolvidos, o surgimento de alguns países como Israel, a divisão de alguns países, a ajuda financeira dos EUA ao Japão e os países europeus devastados pela guerra, as questões geopolíticas mundiais e outros acontecimentos.

Não há menção de nenhum desses fatos nos currículos e muito menos uma relação cotidiana do aluno com a produção do espaço que estava se configurando naquele momento.

\section{Programa de Ensino 1931}

\section{Geographia}

$\mathbf{1}^{\mathrm{a}}$ série - 3h

I. Prolegônens:

Sistema solar. A Terra no Espaço. A lua eclélica. Dia e noite. Estações.Fusos horários. Constelação. Coordenadas da esfera da Terra.

\section{Geografia Física}


Estrutura da Terra. Distribuição das Terras e das marés.

a) Elemento sólido: sua formação, sua composição. Rochas, terrenos, jazidas minerais. Nomenclatura do relevo. Classificação das formas: dobras, deslocamentos, erupções. Montanhas, planaltos e planícies; suas características.

b) Elementos líquidos. Oceanos e Mares. Águas e movimentos do mar, vagas, marés, correntes. O relevo submarino; os lagos. As águas correntes: os rios. A erosão fluvial. Regime dos rios.

c) Elemento gasoso. A atmosfera: pressão, temperatura, umidade. As chuvas. Classificação dos climas (os climas do Brasil como tipos de referência). Erosão atmosférica.

d) Os litorais: tipos de costas. As dunas. Relação com relevo e com as águas adjacentes.

e) A vida animal e vegetal sobre o globo.

\section{Prática de Geografia}

Demonstrações e experiências com telúrio e o pendulo de Foucault. Processos de orientação. Determinação da latitude e da longitude. Hora legal. Escalas. Cópias de cartas. Leitura das cartas. Representações gráficas do relevo. Dados estatísticos.

\section{$2^{\mathrm{a}}$ série -3 horas}

I. Geografia geral dos continentes

Posição. Limites. Dimensões comparadas. Aspectos do relevo e do litoral. Climas e Hidrografia. Vegetação. Animais. Populações. Divisões políticas e cidades. Recursos econômicos. Descrição sumária de cada continente de acordo com as divisões naturais (América, Europa, Ásia, África e Oceania).

\section{Geografia Física do Brasil}

Situação. Aspecto. Dimensões do país. Fronteiras terrestres (histórico e tipos). Relevo e classificação dos sistemas mássicos. O Atlântico Sul, Litoral: morfologia e descrição. Climas; tipos e exemplos especiais; Hidrografia.

\section{Prática de Geografia}

Experiências relativas às formas de relevo. Formação experimental de chuvas. Demonstração da ação das águas sobre o modelado terrestre.

\section{$3^{\mathrm{a}}$ série (2horas)}

\section{Geografia Política e Econômica}

Populações e Raças. Línguas e Religiões. As migrações e a civilização. Colonização e formação das cidades. As Capitais. As estradas, a circulação e os transportes. Fronteiras. Culturais alimentícias (trigo, arroz, milho, café, cacau, chá, assúcar, vinho). Plantas industriais (algodão, borracha, madeiras, fumo). Criação de animais; carnes, peles, couros, lã, seda. Explorações minerais (carvão, petróleo, ferro e outros metais). A utilização das forças naturais.

\section{Geografia Política. Econômica do Brasil}

Populações: grupos étnicos, elementos europeus. Colonização, recenseamentos: os Estados e o DF. Recursos naturais e mananciais de energia. Condições gerais da agricultura: café, cacau, assúcar, algodão. O gado. Indústrias extrativas: borracha, madeiras, mate, manganês. 
Viação férrea e rodoviária. Navegação. Comércio exterior.

\section{$4^{\mathrm{a}}$ série (2horas)}

\section{Geografia dos Principaes Países}

Estudo especial de cada uma das seguintes potências, nas suas feições físicas, políticas particulares, salientando em cada uma delas os problemas de natureza social ou econômica que mais lhe caracterizam a vida internacional:

a) a Inglaterra e o Império Britânico (formação, extensão, estrutura e problemas imperiais)

b) a Alemanha e a Europa Central.

c) a França e suas colônias.

d) a Itália e o Adriático.

e) a Península Ibérica.

f) as Repúblicas Russas.

g) o Japão e sua expansão.

h) a China e as suas dependências.

i) os EU (população, colonização e expansão econômica).

j) a República Argentina.

\section{Geografia Regional do Brasil}

Descrição física e política de cada uma das regiões naturais do país. Estudo especial, um cada região, dos principais problemas econômicos e sociais da atualidade, assim como a sua evolução histórica e Brasil Septentrional. Brasil Norte-Oriental. Brasil Oriental. Brasil Meridional. Brasil Central (em cada região natural, serão estudadas, por Estado, exclusivamente as feições políticas, formação histórica, população, cidades).

\section{$5^{\text {a }}$ série (2horas)}

Geografia Física

\section{Elementos de Cosmografia}

O Sistema solar. Lei de Kepler e de Newton e de Bode. Planetas. Cometas. A Terra. Coordenadas geográficas. Movimentos. A Lua. Eclipses. Marés. Calendário Cartas terrestres. Escala.

\section{Meteorologia e Climas}

A atmosfera: composição; altura. A pressão atmosférica e os ventos. A temperatura do ar: a distribuição; médias térmicas; oscilações e extremos. A umidade e as precipitações. Regimes pluviométricos. A chuva. Os climas da Terra: classificação dos principais tipos. Climas do Brasil.

\section{O Elemento sólido}

A crosta terrestre: sua composição. O relevo do solo; feições principaes. Erosão e tectônica. A erosão fluvial e seu ciclo. A formação dos vales. Tipos de planícies e de planaltos, influência das rochas sobre a topografia. Estruturas características: dobramentos, falhas e fraturas. Relevo vulcânico. Distribuição e classificação dos vulcões. Relevo glaciário. Relevo desértico. Litoral: tipos de costas. Os recifes. 


\section{O Elemento líquido}

Os oceanos e os Mares. Relevo submarino. Águas do mar: salinidade e temperatura. Lagos, correntes, ressacas. Os lagos: formação e evolução das massas lacustres. As águas correntes. O escoamento fluvial. O ciclo vital dos rios. Tipos de regimes fluviais. Estudos do Amazonas, do São Francisco e do Paraná.

\section{Elementos de Biogeografia}

As influências do meio físico sobre a distribuição da vida no globo: as plantas, os animais e o homem. Distribuição dos vegetais: tipos de vegetação: matas, campos, caatingas, desertos frios e quentes. A flora das alturas. Distribuições dos animais: formações aquática, marinha e fluvial. Faunas terrestres nas diferentes zonas. Migrações. As condições da vida do Homem nos diferentes meios.

\section{Geografia comparada das Américas}

Estrutura, relevo e litorais nos continentes americanos. Vegetação e recursos naturais. Zonas fisiográficos. Etnografia e populações: distribuição e densidade; dados estatísticos comparativos.

Este programa de ensino é conteudista, porém com menor proporção que dos outros. Chama-nos a atenção porque tem elementos para estudo do nosso país, até então pouco discutido nos programas de 1850, 1898 (que estará logo adiante).

Notamos uma preocupação para os dois primeiros anos de três horas. Dividiu-se em cinco séries, nos quais mesclaram conceitos gerais do mundo e do Brasil. Os conceitos interligados à Geografia matemática (cartografia e cosmografia), a Geografia Física e Humana (Política, População e Economia) com acentuada discussão sobre a divisão regional natural.

Um currículo enciclopedista, a relação dos conteúdos: $1^{\circ}$ ano - as relações do sistema solar, estrutura da Terra (sólido, líquido e gasoso), o litoral e a vida animal e vegetal e de Prática (com leitura de mapas) situa-se como a geografia era dividida de acordo com os aspectos físicos. No segundo ano a questão da posição geográfica dos continentes, parte física, população, política, recursos econômicos e divisão natural, observamos uma separação visível até pela própria concepção geográfica e pela dicotomia Humana e Física, Político e Econômico e a análise da Região Natural e Territorial fundamentada no Determinismo e uma parte do Possibilismo e conteúdos voltado a divisão política e econômica dos países. 
A seguir os conteúdos são restringidos à Geografia Física do Brasil no qual aponta exaltação das dimensões do país, as fronteiras (território solo), relevo, clima e hidrografia e a posição em relação Atlântico Sul (litoral), ou seja, a princípio sem uma relação com as atividades humanas as quais modificaram essas paisagens.

$\mathrm{Na} 3^{\mathrm{a}}$ série uma relação dos aspectos mundiais sobre População, língua e religião, formação das cidades, as capitais, alguns elementos interligando as cidades, alimentos, plantas ligadas à indústria, pecuária, extração mineral e utilização de forças naturais. Uma mescla da População descritiva e sua cultura, sem levar em consideração as relações com o próprio território e sua paisagem e as relações que elas estão em relação à própria concepção de cidades, das condições econômicas. Na parte humana não aparece uma discussão sobre as funções das cidades, a questão urbana que é latente na Europa e nos EUA, a expansão das indústrias, a produção do trabalho, apesar de aparecer a importância de plantas industriais, as funções relacionadas à agricultura e à pecuária, a relação das explorações minerais seria pertencentes com a questão industrial que não se vincula a nenhum conteúdo.

No Brasil, os conteúdos não fazem uma relação direta com a realidade local. Estão caracterizados a questão dos grupos étnicos, os estados e o Distrito Federal, a agricultura, a pecuária, as indústrias extrativistas, a questão dos meios de transportes e o comércio exterior. Há nesse momento, o desenvolvimento mais acentuado sobre o território brasileiro.

$\mathrm{Na} 4^{\mathrm{a}}$ série observamos os estudos das principais potências da época e o estudo da Geografia Regional do Brasil sendo caracterizada segundo o critério da região natural apontando os problemas econômicos, sociais, políticos e de formação histórica. Elementos relacionados a um estudo mais aprofundado do Brasil, o que nos outros currículos (antes desse) quase não estavam descritos. Os estudos regionais mostram a tendência das regiões monográficas francesas de La Blache e a percepção dos conceitos de paisagem estritamente natural.

O contexto desse momento ao de outros currículos é bem diferente: houve o crash da Bolsa de Nova York, a produção cafeeira do Brasil decaía, uma Guerra Mundial, o surgimento da URSS, o fortalecimento dos EUA, o sistema socialista soviético, a industrialização do Brasil, a urbanização acelerada nas maiores capitais do mundo, as políticas populacionais, as construções de vários arranha-céus e tantos outros acontecimentos não vinculados aos programas curriculares. 
O que analisamos é que em nenhum momento há uma discussão no currículo prescrito sobre as questões que se permeavam naquele momento no mundo ou no Brasil. Apesar de estarem escrito os problemas econômicos e sociais, o que podemos afirmar, conforme a leitura de Vlach (1988), Rocha (1996), Pereira (1989), nesses períodos, os conteúdos brasileiros tem como objetivo exaltar o país. É importante frisar que os principais conteúdos pontuam os aspectos físicos, um conhecimento importante, mas que não agrega de fato o que acontecia naquela época em nosso território, nem mesmo a discussão sobre Política e Economia no Brasil não permitia uma análise mais específica sobre a conjuntura do período.

$\mathrm{Na} 5^{\mathrm{a}}$ série há um retorno das discussões sobre a Geografia Física com os elementos da geografia matemática, o clima, a litosfera, a água, a biogeografia (vegetação) e uma comparação da Américas, ou seja, percebemos nitidamente a divisão Homem-Natureza.

\section{CURRÍCULO DE 1898}

\section{$1^{\circ}$ Anno \\ $5^{\text {a }}$ cadeira \\ Geographia}

Geographia physica - Exercício de cartografia

1. Plano da sala de aula

2. Plano do edifício do estabelecimento e adjacências: sua orientação pelo nascer do sol

3. Orientação pela bússola. Norte magnético. Norte verdadeiro

4. Rosa dos ventos. Pontos cardeas e collateraes

5. Planta da Bahia de RJ - Ilhas principaes

6. Planta do Districto Federal. Montanhas principaes. Lagoa

7. Noção da Terra por meio do globo. Hemispherio norte ou booreal, sul ou astral. Ponto ártico. Pólo Antártico

8. Círculos da esphera: equador, parallelos, meridianos, circulo polar ártico, circulo polar antartido, tropico de câncer, tropico de capricórnio

9. Zonas. Frigida ártico, frigida antártica. Zonas temperadas. Zona tropical.

10. Forma geral e posição relativa dos continentes e dos oceanos.

11. Termologia geographica. Denominações dadas as differentes configurações da parte sólida e da parte liquida da superfície do globo

12. Planispherio. As cinco partes do mundo: sua posição, forma e grandeza. Antigo, novo e novíssimo continentes.

13. Brazil, posição que ocupa sobre a Terra. Estudo geral da Geographia physica do Brazil 14. Estudos no planispherio a) América do Sul b) Brazil, posição que ocupa sobre a Terra 15. Geographia geral das 5 partes do mundo, espacialmente da América: posição, limites, dimensões, aspecto, littoral, mares, golfos, bahias e estreitos; ilhas, penínsulas, isthmos e cabos; systema orographico, pontos culminantes, vulcões, planícies e desertos, vertentes, linha divisória das águas, bacias fluviaes, rios, lagos, flora, fauna, etc.

16. Derrotas de viagem ao redor do globo. 


\section{$2^{\circ}$ anno - Curso Realista}

Geographia política. Exercícios de cartographia. Situação, limites, superfície, descripção physica, população, governo, religião, língua, divisão administrativa, produções, commercio, industria, vias de communicação e cidades principaes dos seguintes paizes:

\section{Brazil}

2. Republica do Paraguay

3. Republica do Uruguay

4. Republica da Argentina

5. Republica do Chile

6. Republica da Bolívia

7. Republica do Peru

8. Republica do Equador

9. Republica de Colômbia

10. Republica da Venezuela

11. Guyanas

12. Brazil

13. Antilhas

14. América do Sul

15. México

16. EUAN

17. Confederação Canadiana

18. Inglaterra e possessões

19. Dinamarca e possessões

20. Suécia e Noruega

21. França e possessões. Principado de Mônaco

22. Bélgica e Hollanda e possessões

23. Allemanha e possessões

24. Áustria - Hungria

25. Suissa

26. Portugal e possessões

27. Hespanha e Republica de Andorra

28. Itália

29. Rússia

30. Rumania, Servia, Montenegro e Bulgária

31.Turquia e Grécia

32. Possessões russas na Ásia

33. Turquia na Ásia

34. Pérsia e Turkistão

35. Arábia, Afaghanistão e Belutchistão

36. Indostão

37. Indo-China

38. China

39. Japão

40. Barbaria e Sahara

41. Egypto, Núbia e Abyssima

42. África Occidental e Colônia do Cabo

43. África Oriental e Central

44. Possessões inglezes na Oceania

45. Possessões hollandezes na Oceania

$3^{\mathrm{a}}$ anno - Curso Realista 


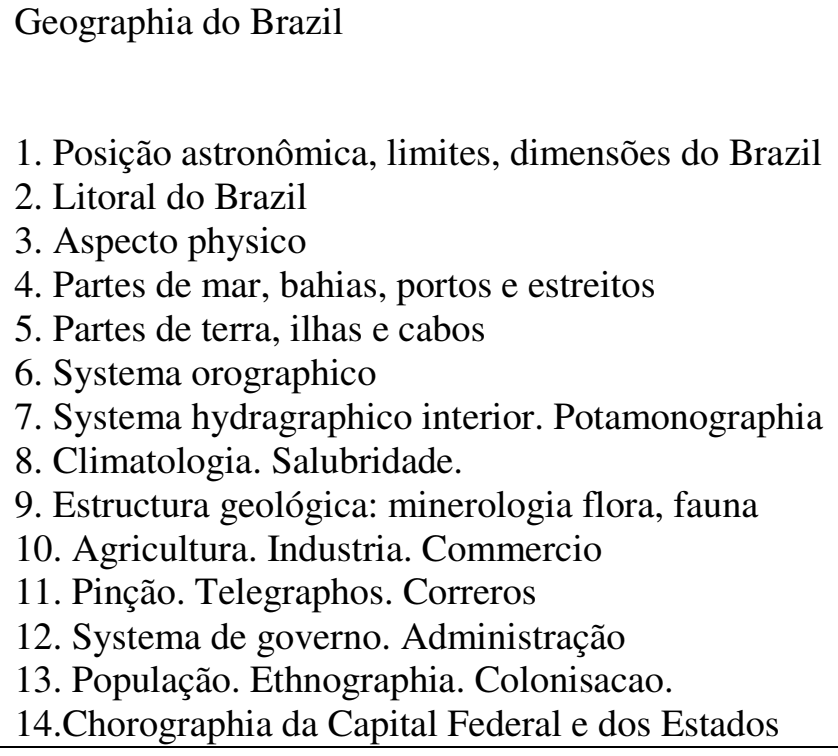

Neste currículo, os conteúdos são direcionados aos conceitos cartográficos, à descrição física e do território, relacionados conforme o estudo da educação francesa no final do século XIX, que se estruturava por meio da observação do uso de mapas, de estudo físico, político e econômico. A concepção curricular brasileira premissa nessa construção na qual no $1^{\circ}$ anno tem-se o estudo da cartografia, $2^{\circ}$ anno Geographia 
política dos países no mundo, no $3^{\circ}$ anno Geographia do Brazil e no $4^{\circ}$ anno noções de cosmographia, sendo que no $6^{\circ}$ anno há uma revisão das Américas, especialmente do Brazil.

$\mathrm{Na}$ análise realizada percebemos que o currículo ainda é conteudista, apesar de uma difereciação para o de 1850. Os aspectos cartográficos estão mais objetivados nesse currículo, com estudo de elementos relevante para a localização e instrumentação e com elementos sobre o território brasileiro. A questão da Geographia Política aparece nesse contexto de forma inter-relacionada (os limites, superfície, populações, governo, religião, divisão administrativa e cidades principaes); Geographia Econômica (comércio, produções e industria) e noções de cosmographia.

Esta concepção conteudista relaciona o Determinismo e traça uma linha Possibilista do cunho das regiões monográficas, porém com descrições os aspectos físicos que estão extremamente presentes. Há uma visão enciclopédica da Geografia incluindo a questão da geologia, do litoral, do clima, da vegetação e dos animais que ainda não estaria relacionado ao currículo anterior, e um direcionamento para as questões da cosmographia (Geografia matemática). Não há uma separação clara dos continentes como percebemos no dia 1930, mas uma descrição de alguns países destes, continentes diminuindo o estudo desses que eram mais acentuadas no currículo de 1850.

Em relação aos conteúdos descritos sobre o Brasil, há uma abrangência sobre o estudo do seu território, principalmente na parte cartográfica. As atividades estão relacionadas às orientações com bússola, rosa dos ventos, localização dos continentes e suas principais dimensões, e das diferentes formas de relevo, a relação que o Brasil ocupa no $1^{\circ}$ anno e no $3^{\circ}$ anno, a relação direta com os conhecimentos do Brazil interrelacionando os aspectos físicos, o litoral, clima, agricultura, indústria e comércio, o sistema de governo (regional), população e os estados. Vemos a configuração do padrão descrito por Moreira (N-H-E).

Percebemos que não abarcou-se as concepções da realidade vivida pelos alunos. Há uma lista de informação a serem "passados" e com uma relação estreita do conceito de território e de região.

Repensando o contexto da época, o Brasil estava inserido no sistema de governo republicano, mas o território ainda estava se constituindo, os sistemas de governo e econômico mudaram, várias revoltas surgiram, vários imigrantes vieram para o país. No mundo estava ocorrendo a Segunda Revolução Industrial, o crescimento das cidades, as mudanças na Divisão Internacional do Trabalho, colonização da África e da Ásia, o 
crescimento do império japonês e estadudinense. E vários outros acontecimentos não descritos.

Chama-nos a atenção ainda uma discussão semelhante ao do passado, um currículo que não interliga o cotidiano brasileiro aos aspectos das transformações espaciais, territoriais, das paisagens muito presentes na época e outra posição de observar e analisar o mundo.

\section{CURRÍCULO DE GEOGRAFIA 1850}

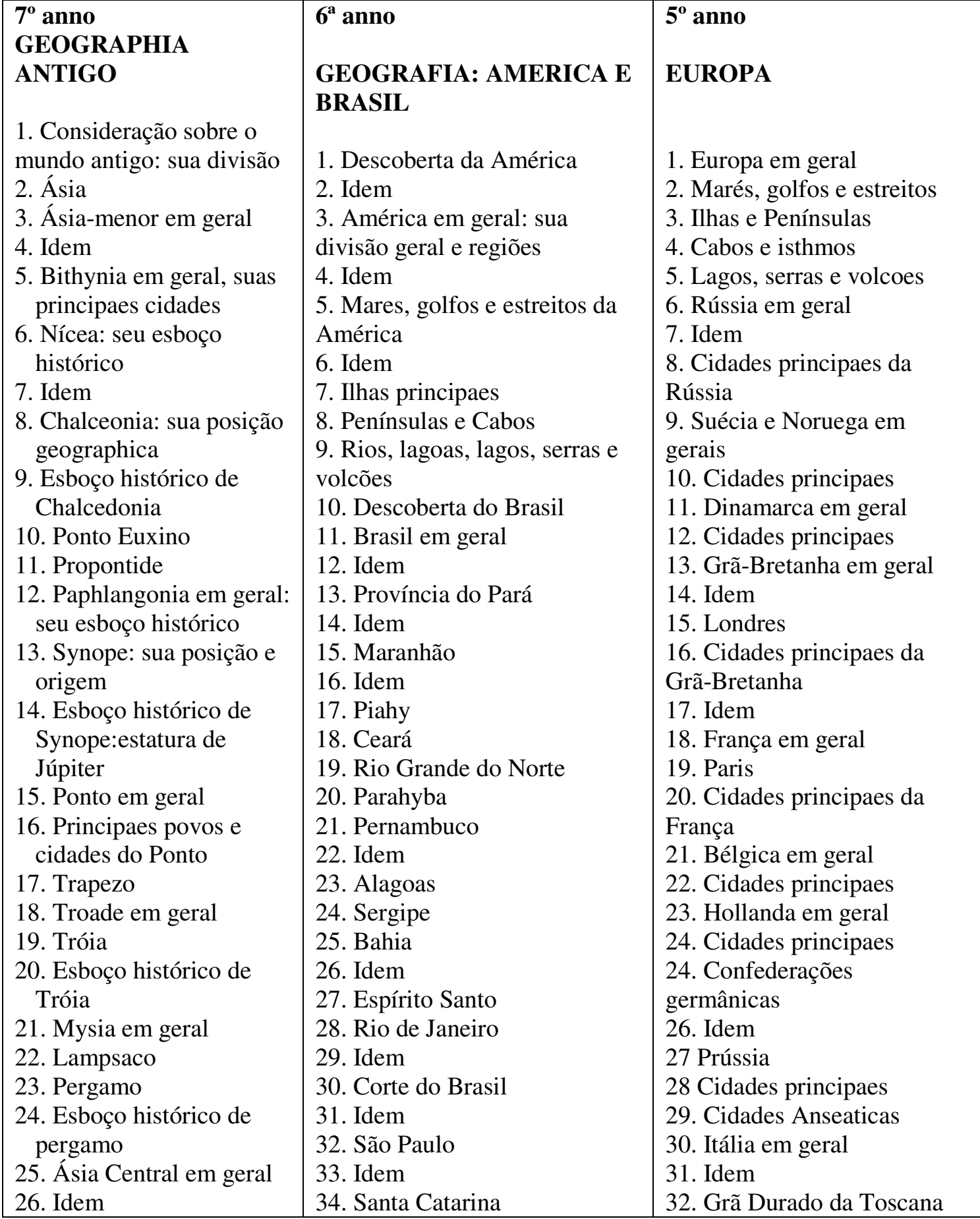




\begin{tabular}{|l|l|l|}
\hline 27. Syria & 35. Minas Gerais & 33. Cidades principaes \\
28. Idem & 36. Idem & 34. Idem \\
29. Palmya & 37. Rio Grande do Sul & 35. Suissa em geral \\
30. Idem & 38. Idem & 36. Cidades principaes \\
31. Phenicia em geral: sua & 39. Goiay & 37. Hespanha em geral \\
cidades principaes & 40. Mato Grosso & 38. Cidade principaes \\
32. Tyro: sua antiguidade & & 39. Portugal em geral \\
33. Tyro e Nabucodonosor & & 40. Cidades principaes \\
34. Tyro e Alexandre & \\
Magno & \\
35. Palestina em geral & \\
$\begin{array}{l}\text { 36. Jerusalém } \\
\text { 37. Esboço histórico de } \\
\text { Jerusalém }\end{array}$ & \\
38. Babylonia ou Chaldea & & \\
em geral & & \\
39. Cidade de Babylonia & & \\
40.História da decadencia & & \\
e das ruínas de & & \\
Babylonia & & \\
\hline
\end{tabular}

\begin{tabular}{|l|l|l|}
\hline $\mathbf{4}^{\mathbf{0}}$ anno & $\mathbf{3}^{\mathbf{0}}$ anno & $\mathbf{2}^{\mathbf{0}}$ anno \\
ASIA & ÁFRICA, OCEANIA & Generalidades \\
& 1. África geral: esboço histórico & 1. Noções Geraes \\
1. Ásia em geral & 2. Golfos, cabos e estreitos & 2. Europa: seus limites \\
2. Rios & 3. Montanhas, rios e lagos & 3. Europa \\
3. Montanhas e Lagos & 4. Mares \\
4. Mares, golfos e cabos & 4. Ilhas & 5. Golfos \\
5. Ilhas, estreitos e & 5. Regiões: desertos e clima & 6. Estreitos \\
penínsulas & 6. Productos naturaes & 7. Ilhaes \\
6. Productos naturaes & 7. População: raças & 8. Penínsulas \\
7. Governos, Religiões, & 8. Religiões e governos & 9. Cabos e Isthmos \\
População & 9. Divisões políticas & 10. Lagos \\
8. Rússia em geral & 10. Egypto: esboço histórico & 11. Serras e vulcões \\
9. Idem & 11. Idem & 12. Rios principaes \\
10. Cidades da Sibéria & 12. Cidade do Egypto & 13. Ásia: seus limites \\
11. Cidades do Cáucaso & 13. Idem & 14. Paizes das Ásia \\
12. Turquia em geral & 14. Barbarie em geral & 15. Mares \\
13. Cidades da Turquia & 15. Trípoli & 16. Golpes \\
14. Idem & 16. Tunisia & 17. Estreitos \\
15. Turkistão & 17. Argélia & 18. Ilhas \\
16. Arábia em geral & 18. Marrocos & 19. Penínsulas e cabos \\
17. Cidades principaes da & 19. Cabo da Boa Esperança & 20. Lagos e montanhas \\
Arábia & 20. Costa de Zanguebue & 21. Rios \\
18. Pérsia própria em geral & 21. Madagascar & 22. África: seus limites \\
19. Cidades da Pérsia & 22. África Portuguesa - & 23. Regiões da África \\
própria & Madeira & 24. Golfos e estreitos \\
20. Kabul & 23. África Portuguesa - Açores & 25. Ilhas \\
21. Belouchistam e Herat & 24. África Portuguesa - Cabo & 26. Cabos \\
22. China em geral & Verde & 27. Lagos e montanhas \\
23. Idem & 25. Ilhas Camoris & 28. Rios \\
24. Civilisação da China & 26. Outras ilhas do Atlântico & \\
\hline
\end{tabular}




\begin{tabular}{|l|l|l|}
\hline $\begin{array}{l}\text { 25. Commercio e Industria } \\
\text { da China }\end{array}$ & $\begin{array}{l}\text { 27. Ilhas do Oceano Indico } \\
\text { 28. Oceania }\end{array}$ & $\begin{array}{l}\text { 29. América: sua divisão } \\
\text { geral }\end{array}$ \\
26. China própria & 29. População e raças & 30. Regiões da América \\
27. Idem & 30. Religiões e governos & 31. Golfos \\
28. Outros Estados da & 31. Notasia em geral & 32. Estreitos \\
China & & 33. Ilhas principaes \\
29. Idem & & 34. Penínsulas e cabos \\
30. Indostão em geral & & 35. Lagos, lajes, serras e \\
31. Idem & vulcões \\
32. Império Anglo-Indico & & 36. Rios principaes \\
33. Idem & 37. Oceania: sua extensão \\
34. Outros estados do & e divisão \\
$\begin{array}{l}\text { Industão } \\
\text { 35. Idem }\end{array}$ & 38. Notano \\
36. Possessões europeus & 39. Austrália \\
37. Índia Transgangetiva & 40. Polynesia \\
38. Cidades da Îndia & \\
Transgangetiva & \\
39. Idem & \\
40. Japão & \\
\hline
\end{tabular}

O primeiro currículo brasileiro foi uma réplica do francês. Observando e analisando este currículo, podemos dizer que se pautava numa relação simplesmente conteudista com pontos interligando a Geografia física e matemática e ao mesmo tempo, algum esboço de acontecimentos históricos.

Podemos nos remeter a contínua discussão de Lacoste (1988) argumentando que este currículo tinha um cunho enciclopédico e decoreba. O programa é bem específico em relação à forma como a construção de uma idéia de Geografia está objetivada num amaranhado do conhecimento territorial proposto por Raztel "território-solo". As relações dos conteúdos feitos do $2^{\circ}$ ano ao $7^{\circ}$ ano apontam numa generalidade de informações: limites, mares, golfos, estreitos, ilhas, cabos e istmos, lagos, serras e vulcões, rios principaes... uma relação que poderia se encontrar em qualquer enciclopédia escrita referências sobre cada "assunto", mas que ao mesmo tempo, que poderia determinar não para escola, mas para o Governo pontos estratégicos para o conhecimento de um país.

Analisava a divisão por continentes e seus principais elementos no $2^{\circ}$ anno; a África e a Oceania no $3^{\circ}$ anno e o domínio europeu; no $4^{\circ}$ a Ásia; $5^{\circ}$ anno A Europa; $6^{\circ}$ anno América e Brasil e $7^{\circ}$ anno Geographia Antiga. Isto significava os conteúdos a serem ministrados por professores que, em muitos casos, eram autodidatas e não professores de Geografia. Todo o conteúdo, como observamos, não trazia um cunho 
patriotista brasileiro, mas um rol de informações com o objetivo de redirecionar o que significava a construção de uma espacialidade entre o sujeito e o objeto do conhecimento professor/aluno.

É evidente, que os próprios conceitos de Geografia estavam direcionados a Paisagem, ao Território e a Região. O conceito de território-solo está embutido neste currículo: os limites, o conhecimento físico, fazem parte de uma conceituação de uma identidade do solo, do "chão" que a Geografia trabalhava. O conceito de Região também está descrito nos conteúdos relacionados a questões administrativas, como a divisão de províncias, países e as cidades principaes.

No $6^{\circ}$ anno aparece a discussão sobre a Geografia do Brasil junto com o continente americano. Observa-se que a preocupação central dos conteúdos brasileiros se dá a uma descrição de suas províncias e uma discussão sobre o relevo e hidrografia. Nada além de um complemento das divisões dos conteúdos sem uma importância a mais dada para ela.

Outro ponto relevante é a falta, no currículo prescrito, da realidade concreta do aluno, percebemos que a intenção real é "passar" uma lista de conteúdos a serem seguidos, sem ter uma relação direta com os acontecimentos e mudanças que aconteceram no país. Nessa época, o país era Reino Unido, houve transformações territoriais, econômicas, sociais, políticas que estão expressas na paisagem e conseqüentemente no espaço. Uma época em que se iniciava a "Segunda Revolução Industrial" e não há uma discussão de indústria como um dos elementos modificadores do espaço mundial, a interferência da Divisão Internacional do Trabalho e das Grandes Navegações para a nova configuração espacial. O que significava estudar a Geografia Antiga (Tróia? Babilônia?) o que isto teria de importante para compreensão da realidade brasileira naquela época? Ou que elementos permitiriam o entendimento do espaço produzido aquela época?

Isto nos leva a interpretar que o governo brasileiro só tinha a intenção de copiar, com ressalvas, o currículo francês, porque a cultura francesa era considerada "a elite do mundo" e uma forma já pré-definida de ter uma organização curricular já pronta. 


\subsection{A interligação entre a história curricular e a produção atual: algumas considerações}

Analisamos os currículos do Colégio D. Pedro II, desde o primeiro, -oficial -, de 1850, que obviamente sofreram mudanças, mas há elementos familiares. Podemos destacar como ponto relevante que nos currículos atuais, há uma preocupação com a contextualização dos acontecimentos da época, uma questão tantas vezes discutida, mas que só vai aparecer com mais clareza no currículo a partir de 1931, e com maior ênfase a partir de 1950.

Percebemos que durante o período de 1850 a 1931, os currículos estavam associados a um predomínio da Geografia Física, nos remetendo ao fato de, o Determinismo ter sido uma referência do pensamento geográfico pelo mesmo até o começo do século XX. As descrições dos aspectos físicos são bem nítidas como Lacoste (1988) argumentava que a Geografia parecia uma enciclopédia com várias informações sem nexos com a realidade da nação e - podemos dizer - dos professores.

A articulação dos currículos, principalmente a partir da década de 1980 com a Geografia Crítica permitiu uma reestruturação na forma de trabalhar com os conceitos, interligando-os com os fatos da época. A leitura dos professores atuais é de justamente a preocupação com os conteúdos do cotidiano que fazem os alunos compreenderem os fenômenos geográficos que os cercam, porque a articulação entre o vivido e o produzido faz com que os alunos entendam o porquê da importância da disciplina no seu cotidiano.

Para isso, foi necessário que os docentes entendessem o que seria mais relevante para estudar a Geografia, tendo como ponto principal a relação entre a cidade e o rural, partindo para uma discussão sobre os meios físicos, sociais, humanos. Desse momento em diante, analisamos que ainda há uma articulação com os currículos anteriores, pois a questão da estrutura dos conteúdos seguiu certo padrão dos currículos principalmente da década de 1980 e de 1990. Essa organização ainda vem do fato que esses professores tiveram uma formação de Geografia interligada a conteúdos sistematizados da disciplina mais "acadêmica" do que especificamente naquelas que apontam o que ensinar para que os alunos articulem o cotidiano ao espaço produzido.

Apontado sempre que dentro da Pedagogia Histórico-Crítica a partir da década de 1970, os conteúdos deveriam se relacionar a questões da sociedade capitalista e dos fenômenos que aconteciam na realidade vivida do aluno. 
Durante a análise dos currículos fica claro que a Geografia se preocupou sempre mais com os conteúdos da disciplina acadêmica em si do que com a disciplina escolar, pois uma coisa é ser professor ou geógrafo e outra são os elementos necessários que os alunos devem saber sobre o ensino de Geografia que os ajudem a fazer uma leitura crítica da sua realidade vivida.

Moreira, R. (1987) nos esclarece que os conteúdos da Geografia brasileira também seguem a mesma tendência da ciência geográfica: a fragmentação da relação $\mathrm{N}$ (natureza), H (humana) e $\mathrm{E}$ (economia). Em todos os currículos aparecem essas contradições dentro do processo tanto escolar como da própria ciência. Por mais que os professores tenham tentado articular os saberes geográficos, verificamos que ainda há essa tendência à fragmentação. Deixamos claro, que o movimento deve ser feito para que a cada dia, os conteúdos geográficos sejam entendidos como parte de um todo, e não fragmentos.

Isto não quer dizer que todo o momento vai se articular, mas o fato é que ao estudar o clima, por exemplo, a concepção é compreender os processos de transformação do espaço e dos seus objetos de estudo repensando na interligação do clima ao processo urbano, rural, da população, já que as condições atmosféricas e climáticas interferem nas dinâmicas sociais, políticas, ambientais e econômicas.

Neste sentido, averiguamos a dificuldade dos professores na tentativa da articulação dos fenômenos físicos, sociais e culturais para uma maior articulação com o espaço vivido dos alunos. Mas, vemos que isso é um problema dos próprios teóricos da Geografia que ao longo dos anos sempre privilegiou o engavetamento dos conteúdos conforme a argumentação de Moreira, R. (1987) na relação da organização dos conteúdos: a natureza, o homem e depois os aspectos econômicos. Evidentemente, que nesses anos, o ensino de Geografia, trata de outra questões ligadas à parte geopolítica, da cultura, do meio ambiente, mas que de certa maneira continuamos trabalhando com conteúdos que ainda não articulam o cotidiano dos alunos.

Dentro dos currículos, a relação dos conteúdos sobre o espaço brasileiro só será discutida e contextualizada no currículo de 1950, quando encontramos a divisão por séries específicas para estudar o Brasil. A organização começa a ser relacionada com os acontecimentos da época, o que mostra que a Geografia, mesmo de forma ainda pequena, já direciona seus conteúdos a pensar sobre a análise dos aspectos humanos e físicos, que são fragmentados em Geografia Física e Geografia Humana (mesmo sabendo da camuflagem das informações que ainda não associam às mudanças espaciais 
decorrentes dos interesses dos governantes brasileiros; da discussão sobre os problemas com a terra, do urbano e do rural; transformações da paisagem que o país estava sofrendo. A percepção desses acontecimentos, visualizamos nos currículos de 1980, 1990 também a dos professores, mostrando a relação, por exemplo, da rede do narcotráfico, da biopirataria, das questões sobre o consumo com cotidiano do aluno.

Assim disso há a questão da relação da Cartografia. Depois do primeiro currículo, verificamos a preocupação com a localização dos países, dos continentes, dos estados. É evidente que a Cartografia não seja só isso, mas uma coisa era certa para os geógrafos e os professores de geografia, que o mapa era um instrumento importante dentro do ensino e o que nos diferenciava das outras disciplinas. Capel (1982) relata que a cartografia ensinada na escola tinha objetivos técnicos (se tornarem mini-cartógrafos) e não os da alfabetização e letramento cartográfico ${ }^{14}$.

Hoje podemos perceber que a preocupação do ensino da cartografia está mais direcionada a orientar o aluno a se perceber no espaço, por meio dos diversos conteúdos e conceitos da cartografia escolar.

É importante mencionar que o ensino de Geografia, com o decorrer do tempo, foi tentando romper com algumas situações do currículo passado, e que de certa maneira foi sendo apropriado a partir do momento em que houve também uma transformação no modo de pensar a formação do professor e de sua metodologia e prática. Desde Delgado de Carvalho há a discussão da contextualização do currículo, a realização de trabalhos de campo com os alunos para a compreensão da realidade, a utilização de materiais pedagógicos para orientar a aprendizagem. Contudo, na década de 70 é que observamos uma maior articulação dos diferentes instrumentos pedagógicos para a organização dos conteúdos mais inter-relacionados com a aprendizagem.

Desse aspecto, os professores buscaram direcionar um olhar pedagógico para a dinâmica da construção do currículo. Preocupando-se em como ensinar, quais competências e habilidades que os alunos devem ter ao estudar a Geografia. Lembrando-se que os compêndios e aos materiais de cartografia eram os recursos mais utilizados pelos professores, e analisarmos até hoje o livro didático é a maior referência utilizada na sala de aula.

\footnotetext{
${ }^{14}$ Sobre a questão da alfabetização cartográfica, ler ALMEIDA, R. D. de. Uma proposta metodológica para a compreensão de mapas geográficos. Tese (Doutorado em Educação). 1994. Faculdade de Educação da USP, São Paulo, 1994. CASTELLAR, S. M. V. Alfabetização em Geografia. IN: Espaços da Escola. Ijuí-RS: Ed. Ijuí. v 10, no 37, 29-46 p. Jul/set. 2000; SIMIELLI, M. H. Mapa como meio de comunicação: implicações no ensino de Geografia do primeiro grau. 1986. 205 p. Tese (Doutorado em Geografia). FFLC - USP. São Paulo, 1986.
} 
A relação dos conceitos-chave da Geografia é outro ponto à parte. Observamos que a partir do currículo de 1950, fica evidente na relação de conteúdo, os conceitos de Região, Espaço e Paisagem. A relação descrita no currículo, é a concepção geográfica do Determinismo ao destacar que os estudos são direcionados a parte da concepção natural. Já dos da década de 1980 e 1990, os conceitos-chave da Geografia como: Território, Paisagem, Região, Espaço estão descritos na concepção geográfica crítica, buscando a articulação dos aspectos econômicos e da sociedade capitalista.

Quanto aos professores das escolas estaduais, já agregam ao estudo, além dos citados, também o Lugar, fazendo uma relação da Geografia Humanística, Cultural e Crítica, com embasamento em Santos $(1996)^{15}$, o qual menciona que o Lugar, ao mesmo tempo em que é o mundo, também é o indivíduo e suas relações com o espaço em que vive. Além disso, os professores trabalham as regiões não só pelo viés econômico, mas também através da análise do meio técnico-científico-informacional, com o objetivo de mostrar os alunos como o espaço é um conjunto indissociável dos objetos técnicos e da ação humana que estruturam, organizam e reorganizam o espaço de vivência.

Os elementos curriculares descritos pelos professores nos dão possibilidades de longas discussões sobre as escolhas dos conteúdos, suas diversas relações com os outros currículos. O que nos chama a atenção e já concluindo é que de certa maneira, os professores das escolas estaduais, apesar de não conseguirem articular totalmente a relação dos conteúdos geográficos com o cotidiano dos alunos, nos permitem pensar no que eles querem ensinar.

Ao organizar o currículo mostrando ao leitor o que entendem por Geografia; qual sua função, para eles, na escola; as habilidades e competências que querem abarcar, os conceitos e os conteúdos a serem ministrados; a relação dos materiais pedagógicos importante para a prática pedagógica e a questão da avaliação, nos fazem pensar no "salto" que o ensino de Geografia deu desde os seus primórdios em meados do século XIX na Europa quando também a relação se fragmentava nos estudos da geografia matemática e da geografia física, para hoje.

Apesar de muitas discussões, podemos considerar na preocupação com o fato de que a disciplina que dê conta em ensinar que o aluno seja um sujeito que saiba ler o espaço em que vive.

\footnotetext{
${ }^{15}$ SANTOS, Milton . A Natureza do Espaço: técnica e tempo, razão e emoção São Paulo: EDUSP, 1996. no capítulo 14 retrata a questão do Lugar e o Cotidiano.
} 